Vanessa Gabriel da Silva Arruda

\title{
CÉLULA-TRONCO EMBRIONÁRIA: \\ CORPO, ESPÍRITO, TÉCNICA E POLÍTICA
}

Dissertação de mestrado apresentada à disciplina de Filosofia do Direito sob orientação do professor Ari Marcelo Solon

Faculdade de Direito do Largo São Francisco

Universidade de São Paulo 
Vanessa Gabriel da Silva Arruda

Célula-Tronco Embrionária:

Corpo, Espírito, Técnica e Política

Dissertação de mestrado apresentada à Faculdade de Direito do Largo São Francisco como exigência para obtenção de título de mestre em Filosofia do Direito sob a orientação do professor Ari Marcelo Solon.

Faculdade de Direito do Largo São Francisco

Universidade de São Paulo 
Arruda, Vanessa Gabriel da Silva

Célula- tronco embrionária:corpo, espírito,técnica e política/ Vanessa Gabriel da Silva Arruda- Faculdade de Direito do Largo São Francisco, 2009.

1.Filosofia do Direito.I-Vanessa Gabriel da Silva Arruda.IICélula-tronco embrionária:corpo, espírito técnica e política. 
BANCA EXAMINADORA

Faculdade de Direito do Largo São Francisco 
Universidade de São Paulo

2009

Aos meus pais pelo apoio e carinho. 
Agradecimentos

Ao CNPQ pela concessão da bolsa de pesquisa durante o período de 2006-2008. 


\title{
Resumo
}

Este estudo tem por objetivo mostrar algumas das questões relacionadas à célulatronco embrionária no que diz respeito ao início da vida como tem sido tratado pela física, pela biologia e pela religião. Faz-se também uma análise sobre a medicina como técnica médica e as repercussões disso na política.

Palavras-chave: Célula-tronco embrionária. Técnica. Corpo.

\begin{abstract}
This study intends to discuss some questions about embryos in beggining of life's concept and its treatment by physics, biology and religion. Also analyses the medical technic and its reflections in politics and rights.
\end{abstract}

Key Words:embryos, technic, body. 


\section{Sumário}

Introdução

Parte I- A questão do Início da vida

1- O início da vida na Física

2- O início da vida na Biologia

3-Religião e célula-tronco embrionária-o início da vida

....3.1-A célula-tronco embrionária vista como corpo humanoAs cosmogonias planetária e humana- a criação do homem p.30 como repetição da criação do mundo.

.....3.2-Homens gerados por deuses - a noção de parentesco p. 34 cósmico com a criação da Terra e a noção de gestação humana.

Conclusão - Parte I p. 42

4- O Caminho da medicina como técnica p. 44

...4.1- O que é célula-tronco? p.51

5-O corpo cartesiano- objeto de pesquisa p. 53

6- A terapia de célula-tronco- A questão da técnica p.60

Conclusão Parte II p.70

Parte III- O corpo na política

7- A reificação do homem- a questão da dignidade p.71

8- Célula-tronco embrionária - o corpo em juízo. 


\section{INTRODUÇÃO}

A primeira vez que ouvi o termo célula-tronco, foi em uma aula de Imunologia na Faculdade de Medicina. Pelo que aprendemos na época, as células-tronco eram as formadoras das células de defesa do organismo. O professor da disciplina de Imunologia na ocasião, informou que estas células estavam sendo estudadas com a intenção de produzir tecidos orgânicos. Na época achei que isto seria maravilhoso! Há sete anos, já na faculdade de direito, fiz minha tese de conclusão de curso inspirada no tema da clonagem: a Dolly ( a ovelha clonada a partir de uma célula somática) era o assunto do momento e até novela fizeram sobre isto! Recordo-me também que um certo cientista italiano e um outro coreano disputavam a "patente" sobre o primeiro clone humano. Estava aberta a discussão! Hoje, não se fala em clonagem humana, mas pesquisando, experimentando, os cientistas chegaram à célula-tronco embrionária,não por que quisessem, acredito mais que a causa tenha sido acidental ( ou não?) combinação de precariedade técnica com a vontade de ter filhos: sabe-se que as células-tronco embrionárias se originaram do método da fecundação "in vitro", realizada primeiramente em grande escala em bovinos: se funcionava com as vacas ( o que às vezes não era tão certo e nasciam bezerros com mais patas do que o normal), porque não fazer em humanos:casais que, por qualquer razão não podiam ter filhos e tinham posses, recorriam ao método que dava certo, até demais!

Ocorre que os embriões congelados começaram a se acumular nas clínicas e isto até hoje incorre em gastos: paga-se uma taxa para manter os embriões congelados. Após três anos a maioria não é mais considerada viável e é descartada! A genética então passou a realizar pesquisas com estes embriões, primeiro de ratos e depois, humanos: mas eram 
humanos!Aí se iniciou uma nova discussão: teriam alma ou não? Seriam humanas mesmo? Considerando-as humanas, seria lícita a sua utilização em pesquisas? De que maneira se poderia provar a sua humanidade?

Explorar o território das células-tronco embrionárias é remexer em questões antigas sobre o início da vida e a condição do homem na Terra.

Desde o seu aparecimento a vida humana tem sido questionada em muitas áreas da ciência e da religião. $\mathrm{O}$ assunto foi muito polemizado e algumas das questões relativas aos embriões, como as propostas acima, continuaram sem resposta, mesmo que se tenha dado uma solução jurídica para o caso.

De fato, a pesquisa relativa a este estudo praticamente se fez sozinha. Como se observássemos um fenômeno da natureza, um eclípse. A pesquisa, ela mesma, acabou se revelando .

Para desenvolver o trabalho achamos por bem dividí-lo em partes:a primeira parte traz as noções sobre o início da vida referente as áreas da ciência e da religião que mais fizeram debates sobre o assunto. A segunda parte, fala do caminho da experimentação o desenvolvimento da técnica e a maneira como a célula-tronco está inserida neste contexto experimental. A terceira parte traz a condição política do homem. Cabe dizer, por enquanto que a pesquisa foi se conduzindo do início até o fim entre as polaridades estabelecidas pela dissociação entre corpo e alma. Gostaríamos também de dizer que as epígrafes criadas se baseiam nos assuntos tratados e tiveram por objetivo proporcionar uma certa "leveza" a um assunto que parece tão árduo!

Por enquanto é o que temos a dizer! 


\title{
PARTE I - A QUESTÃO DO INÍCIO DA VIDA
}

\author{
1- O início da vida na Física
}

Já de início, peço licença para contar-lhes uma estória....

"Estavam reunidos no laboratório de experiências os mais brilhantes cérebros, autoridades em física, alguns cientistas premiados aguardando ansiosamente o funcionamento do acelerador de partículas. Pela primeira vez o aparelho seria testado e, dependendo do seu funcionamento, o mundo do homens ficaria sabendo como a vida teria começado: como teriam se formado os planetas, as estrelas as diversas galáxias e tudo o mais que se encontra no Universo. Durante o experimento uma mosca muito curiosa adentrou o gigantesco laboratório e percebeu que os pensamentos se desencontravam, Alguns cientistas, torciam contra o experimento,isso mesmo: torciam contra! Não poderiam suportar a notoriedade de seus colegas de profissão, alguns achavam até que estariam completamente arruinados se aquele experimento desse certo: seria o fim de suas carreiras! Outros, mais altruístas, ou talvez imaginando-se na entrega do prêmio Nobel da Física, rezavam para que tudo desse certo( é, às vezes, até os cientistas rezam)!A mosca achou tudo muito interessante e ficou ali, xeretando pensamentos, coisa que uma mosca sabe fazer muito bem, pensou:se eles conseguirem criar um microuniverso aqui neste laboratório, talvez eu possa procurar um planeta para morar e dar início ao planeta das moscas, ah, pensou a mosca:- seria um paraíso, sem inseticidas e mata-moscas, com carne putrefada para todos os lados..., bem mas, antes de ter carne morta, a carne terá que estar viva pra depois morrer, hum, o planeta Mosca precisaria de outros animais e animais e plantas para alimentar estes animais, e se algum animal se alimentasse de moscas? Isto seria um problema.... Assim, meio perdida no seu mundo de fantasia, a mosca não percebeu que o acelerador de partículas havia sido acionado, mas percebeu quando, subitamente apareceu no meio da sala um ínfimo ponto negro. Os cientistas não perceberam, mas ela, como era pequena e tinha muitos olhos, olhos especiais, viu que se tratava de um minúsculo buraco negro (é preciso avisar ao leitor que a mosca,por frequentar o laboratório, já estava familiarizada com certas coisas do mundo da Física...). Bem, para espanto da mosca o buraco negro começou a crescer, crescer, os cientistas que não estavam vendo nada,porque só enxergam pela via da Física, finalmente perceberam que a coisa era séria e quanto mais temiam, quanto mais nervosos ficavam mais o buraco aumentava e já começava a sugar para seu interior lápis, canetas e borrachas, além de outros pequenos objetos. A 
mosca também ficou receosa de ser engolida, mas havia recentemente entrado, furtivamente, em uma aula de yôga e aprendera a meditar, assim em estado de paz interior, a mosca saiu zunindo pela sala, soprando nos ouvidos dos cientistas para que se aquietassem e pensassem em coisas boas. Surpreendentemente os cientistas assim procederam e o buraco negro ( que se alimentava de tudo que era muito negativo, inclusive os pensamentos perversos) foi diminuindo, diminuindo até desaparecer. Neste ponto, para felicidade geral, o aparelho apresentou algum defeito e parou de funcionar. Os cientistas se reuniram para avaliar o experimento e através de cálculos complicadíssimos chegaram a conclusão que, mesmo que tivessem conseguido criar nem que fosse, um microcosmo, não saberiam o que fazer com ele. Era uma pena! Dar o pontapé inicial na formação de um universo parecia tão simples!Mas e depois? O que fariam com o Universo criado, será que teriam que intervir na formação de suas inúmeras e diversas estruturas? Sabiamente reconheceram que o projeto não era conhecido em seus detalhes: era como construir uma casa com apenas a planta e a força de vontade, não saberiam que material usar, o que fazer com ela depois de pronta, que tipo de vida a habitaria? Teriam que pesquisar mais, muito, muito mais...Decidiram então, adiar o experimento e cuidar um pouco dos problemas ambientais e humanos da Terra, o que, por si só já daria muito trabalho!” ( criação pessoal da autora)

O que teria o Universo haver com o início da vida humana?Coincidência ou não as primeiras perguntas feitas neste sentido partiram da Filosofia, além disso as notáveis cabeças pensantes da filosofia ocidental cumulavam várias funções: eram filósofos, mas também físicos, matemáticos...Assim é que, os primeiros questionamentos sobre o início da vida buscavam o início do "início de tudo",pouco importando ser esta uma pergunta da física, da filosofia, da biologia ou da teologia !

Pesquisando-se este tema, nota-se uma certa confusão entre estas áreas de conhecimento: o conceito de vida encontra-se presente em todas elas, é como se a "vida" fosse um modelo em um desfile de modas: cada estilista veste a modelo com a sua concepção pessoal! O conceito sobre o início da vida também pode passear entre as concepções até mesmo se utilizar de conceitos alheios para explicar o seu próprio conceito, neste sentido, a biologia parece ter esperado a física se desenvolver: para que surgisse a vida em seu conceito biológico, precisou-se de um "habitat" para esta vida,um planeta que ora era quente ora era frio, fechado em um sistema de gases, por ação de descargas elétricas ( até aqui física e também química, etc...)de repente passou a ter vida biológica ( então a biologia) e por trás de tudo, uma inteligência superior para dar o empurrão inicial ( será? Diria a física...)!Na metáfora cartesiana" da "árvore do saber", a metafísica

1 “ "Para Descartes os ramos da árvore do saber são a mecânica, a medicina e a moral." "Descartes os coloca como ramos porque são esferas de saber que se ligam a outras mais fundamentais e ao mesmo tempo derivam delas, como numa árvore os ramos se ligam ao tronco e dependem dele para existir, o qual 
corresponderia às raízes da árvore, o tronco seria a física e, deste tronco partiriam as demais ciências.

Desta forma, se a Física se refere à uma partícula incandescente, a Biologia se refere à célula como a menor partícula viva e a Teologia porém, apesar de seguir o mesmo padrão cosmogônico, começa sua estória com o caos e por trás de tudo, Deus!

Afim de que certos aspectos relativos à vida humana e à célula-tronco embrionária possam ser melhor discutidos gostaríamos de mostrar um pouco de cada uma dessas concepções e a maneira como elas se encadeiam para formar o conceito de vida.

O que teria haver o início do Universo com o início da vida?Resposta: a ciência ainda não descobriu vida ( do modo como concebe) em outros planetas. Não se concebe a vida biológica, e no que interessa, a vida humana, fora de seu habitat! Apesar de toda a parafernália tecnológica inventada, o homem não conseguiria viver no espaço sideral ou mesmo no mar sem equipamentos que permitissem o funcionamento de suas funções vitais dentro dos padrões de normalidade esperados para seu organismo. O homem precisa de “condições" para viver.

Quando um estudante de ensino médio se depara com a disciplina de Química, tão logo tenha aprendido certos preceitos depara-se com certas equações matemáticas envolvendo grandezas estranhas, moles, números de moléculas e átomos e neste "mundinho invisível” a olho nu, as tais equações devem ser feitas sempre à luz das CNTP (condições normais de temperatura, valores pré-estabelecidos para fins de cálculos). Mas o homem vive na Terra há 200.000 anos tendo-se adaptado às mais diferentes condições de temperatura e pressão, isto significa dizer que o corpo humano é capaz de suportar variações climáticas, mas só até um certo limite. Temeroso de sua extinção, o homem passou a se preocupar com o resultado de suas próprias ações sobre o meio: buracos na camada de ozônio, o derretimento dos pólos e a perda da capacidade respiratória do planeta (entenda-se desmatamento acelerado, bem como a poluição de mares que têm dizimado à flora marinha, responsável, em grande parte, pela fabricação de oxigênio atmosférico) levaram a algumas conseqüências: a legislação ambiental mundial têm-se mobilizado, através de tratados e convenções, comprometendo-se a, no mínimo, preservar o que ainda resta, nem sempre com a adesão de todos os países, a exemplo do que ocorre com o Protocolo de Kioto, o homem tem aprendido, a duras penas, que sua vida depende da vida da Terra.

por sua vez depende das raízes. Assim também, nesse caso, a física depende da metafísica, na qual estão suas raízes, isto é, seus fundamentos, e a moral, a medicina e a mecânica dependem da física, são como que suas aplicações.In:SILVA, F.L. A metafísica da Modernidade. São Paulo:Moderna,p.93. 
Como dissemos anteriormente, desde a Antiguidade o homem tem se perguntado sobre a origem da vida .

\section{Segundo Hans Küng²:}

“Já para os antigos gregos a pergunta pelo "início" ( em grego arché) de todas as coisas constituía um dos problemas mais importantes da filosofia. No início do século $6^{\circ}$ a.C.os antigos filósofos jônicos admitiam um princípio único, do qual todas as coisas teriam surgido:Tales de Mileto a água, Anaxímenes o ar, Heráclito o fogo, mas Anaximandro o "ilimitado" ( em grego apeiron) e o "divino" ( em grego theion). Mas então, no século5 $5^{\circ}$ a.C., Anaxágoras, um dos filósofos da era mais recente, contrapõe à matéria do mundo o "espírito" independente ( em grego noús) que ordena o mundo.”( Küng, Hans, 2005,p.69).

Então: fogo, água e ar, Deus, estes foram, segundo alguns dos filósofos présocráticos, os princípios formadores do Universo. Séculos depois, Platão ${ }^{3}$ traria uma nova hipótese: no diálogo chamado Timeu, Crítias propõe a Sócrates que Timeu, por ser melhor astrônomo deveria: "Tomar a palavra e, partindo do nascimento do Mundo, terminar pela natureza do homem." ( Platão). A primeira impressão que se tem é a de que o pensamento filosófico repete a sequencia de criação do Universo tal qual ela foi explicada pela Física, (o que também se repete no pensamento religioso): primeiro cria-se o mundo para depois criar-se o homem, diríamos mais: o Timeu de Platão apresenta-nos um cosmo antropomórfico e traz noções relevantes sobre a alma e o corpo. De acordo com Platão, o mundo material nasce e morre mas não existe de fato. A existência real para Platão é característica atribuída a Deus. Sem entrarmos em considerações existenciais, o que poderia render uma tese extra, a criação do cosmos na visão platônica, tanto no que diz respeito à alma quanto no que tange ao corpo, implica uma "causa" ou seja: "Ademais, tudo o que nasce, nasce necessariamente pela ação de uma causa,pois é impossível que seja lá o que for possa nascer sem causa".(Platão). Ainda em outro trecho Platão continua a afirmar: "Mas tudo o que nasceu, é necessário, como dissemos, que tenha nascido pela ação de uma causa determinada." (Platão.

Sobre a criação do mundo proposta por Platão ${ }^{4}$ faz-se necessário ressaltar dois aspectos importantes:

1-o primeiro aspecto corresponde à anterioridade da alma provida de intelecto e posterior criação do corpo cósmico:“(...) que o intelecto só pode nascer unido à Alma. Em virtude dessas reflexões, após ter colocado o Intelecto na Alma, a Alma no Corpo, formou o Cosmos, para dele executar uma obra que essencialmente fosse a mais bela e a melhor."

2- O segundo aspecto refere-se à afirmação de que o cosmos é um ser vivo:"Cosmos, que é

2 KÜNG, H. O Principio de Todas As Coisas-Ciências Naturais e Religião.Petrópolis:Vozes,2005,p.69.

3 PLATÃO. In: Timeu e Crítias ou a Atlântida,São Paulo: Hemus,p.77.

4 PLATÃO. Passim. 
verdadeiramente um ser vivo provido de Alma e Intelecto, é assim gerado pela ação da Providência de um Deus."

Além disso, Platão ${ }^{5}$ diz que, aquilo que nasce deve ter um corpo: "Ora, evidentemente,é necessário que o que nasce seja corporal."

Ao invés de buscar a origem do corpo cósmico em um só princípio (como a proposta de seus antecessores), Platão uniu todos estes princípios como matérias formadoras da alma, assim: fogo e água foram utilizados para formar "o corpo" em um plano, enquanto, terra e ar ( colocados entre o fogo e a água) conferiram uma proporção bidimensional e esférica ao Cosmos.

Ao tratar da alma do mundo, Platão propõe uma estrutura de tripartição:uma primeira parte é formada anteriormente ao corpo, uma segunda parte formada pela junção do corpo e da alma indivisível e uma terceira parte que seria uma mistura das duas anteriores:

" Mas Deus formou a Alma antes do Corpo: mais antiga pela idade e pela virtude, para comandar, e o corpo para obedecer. Eis que de que elementos e de que maneira: da substância indivisível, que se comporta sempre de maneira invariável, e da substância divisível, que está nos corpos entre os dois, misturando-os, uma terceira espécie de substância intermediária, compreendendo a natureza do Mesmo e a do Outro. E assim formou-a entre o elemento dessas duas realidades e a substância dos corpos. Depois tomou essas três substâncias e combinouas em uma única forma, harmonizando à força com o Mesmo a substância do Outro, que se deixava a custo misturar.( Timeu, p. 85-86), ainda: “A Alma é então formada da natureza do Mesmo, da natureza do Outro e da terceira substância.”( Platão.Timeu, p. 91).

Ressalte-se que, até então Platão referiu-se à criação do Cosmos:( apesar de se ter a impressão que ele fala do homem). Mais adiante, Platão descreverá a criação do homem a partir da ação das divindades olímpicas, por enquanto permaneçamos no que que diz respeito ao Cosmos...

Segundo Küng(2005):

"A palavra grega " cosmos" tem uma longa história. Originalmente significa "ordem - é pela primeira vez mencionada em Homero, no século oitavo antes de Cristo,para o exército em ordem de batalha. Em seguida " ornato" - primeiramente comprovada em Pitágoras no século sexto a.C.E por último, na mudança da era, " harmonia", aplicada ao universo, e mais tarde "ordem do mundo" e " universo" como hoje."(Küng,2005,p. 14)

$\mathrm{Na}$ opinião de $\mathrm{Küng}^{6}$, os astrofísicos, baseados em cálculos, têm condições de descrever com precisão o princípio do cosmos na visão da ciência e parece haver um 
consenso entre os cientistas quanto à criação do mundo, quase um modelo padrão, como se descreve:

\begin{abstract}
"No princípio, toda energia e matéria se encontrava comprimida em uma bola de fogo primordial inimaginavelmente pequena e quente, de pequeníssima extensão, como também de enorme densidade e temperatura. Uma mistura de radiação e matéria, tão densa e quente que nela não podiam existir galáxias nem estrelas.(...) há 13,7 bilhões de anos ( este o cálculo mais recente dos astrofísicos), com um estouro inicial; uma gigantesca explosão cósmica, nosso universo teve início. Expandiuse e tornou-se rapidamente mais frio, mas depois de um centésimo de segundo tinha ainda uma temperatura de 100 bilhões $\left(10^{11}\right)$ de graus Celsius e uma densidade cerca de 4 bilhões de vezes maior que a da água. Já nos primeiros segundos, a partir de fótons extremamente e energéticos, devem ter-se formado partículas elementares, sobretudo prótons e nêutrons, e suas antipartículas, bem como partículas elementares leves, particularmente elétrons e pósitrons. Depois (...) foram formados núcleos de hélio, e algumas centenas de milhares de anos mais tarde, com a captura de elétrons, também átomos neutros de hidrogênio e hélio. Depois de talvez uns 20 milhões de anos - baixando a pressão dos quanta de luz originalmente muito energéticos, e baixando também a temperatura -, o gás pôde, pela força de gravidade, condensar-se em acumulados de matéria, e por último em galáxias, em talvez 100 bilhões de vias lácteas, cada uma, em média, com mais de 10 bilhões de estrelas. A gravitação faz as nuvens de gás, ao colapsarem sob o próprio peso, se condensarem em estrelas. Nestas ocorrem reações nucleares que, além de hidrogênio e hélio, produzem agora também elementos pesados, como carbono, oxigênio e nitrogênio. Com o tempo algumas dessas estrelas tornam-se instáveis, explodem e lançam no espaço interestelar quantidades inimagináveis de material. Só com as estrelas de segunda geração, que além de hidrogênio e hélio contém também elementos pesados,(....) se formou o nosso Sol. Parte do material condensou-se em planetas, que agora contém também carbono, oxigênio, nitrogênio e outros elementos pesados indispensáveis para a vida. Só esta segunda geração de estrelas e planetas é que possui as condições para o desenvolvimento da vida e da consciência.”(Küng,2005)
\end{abstract}

Apesar de não terem formulado uma hipótese tão minuciosa,os pré-socráticos não estavam tão enganados:se olharmos atentamente poderemos ver que estão presentes neste modelo "padrão científico", o fogo de Heráclito, a água de Tales de Mileto, o ar de Anaxímenes. Nota-se também o quanto de metafísico e de filosofia se associaram para formar tanto o pensamento pré-socrático, quanto o platônico.

A Física porém não simpatiza com a idéia do singular.: a causa primordial,a singularidade (no caso do espírito) os obrigaria a continuar investigando, a singularidade não se repete em padrões comprováveis. De acordo com Küng?

“(...)a singularidade inicial,porém, trata-se de algo fundamentalmente diferente, algo que se subtrai a todos os conceitos e a todas as leis físicas. Já um centésimo de segundo após a explosão inicial vigoram leis da física

7 KÜNG, H., Opus cit., p.70-71 
que nos são bastante conhecidas. Mas para o tempo 0 , e pra a causa da misteriosa explosão primordial, o físico fica um tanto perturbado. Como poderia ele explicar que em uma minúscula unidade, de densidade, temperatura e impulso infinitos, esteja contido todo o potencial de cem bilhões de galáxias? Só depois de conseguir explicar as condições iniciais é que ele terá condições de explicar as peculiaridades do nosso universo." ( Küng, 2007,p.70-71)

Com a rejeição da idéia de causa primordial, visto que a Física,enquanto ciência deixou de se interessar por questões de ordem metafísica, esta causa inicial chamada por muitos de "Deus" ficou relegada ao terreno da religião. Neste sentido, talvez a dificuldade maior seja descobrir o método científico de lidar com esta e outras questões inerentes ao espírito. O caminho mais fácil porém para não se tentar qualquer tipo de investigação sobre isto é dizer simplesmente que não existe, em contrapartida,como diria Küng: "Acreditar na hipótese científica da explosão sem explicação de uma diminuta partícula em milhões de galáxias não seria também crer numa espécie de mito científico?’(Küng,p.71).

Importa considerar, de acordo com o que foi exposto até o momento que, temos na Física um conceito de vida em "sentido amplo", ou seja, a vida presente no Universo. Talvez alguns considerem isto em relação ao conceito de vida biológica que pretendemos apresentar adiante. Talvez alguns ainda não entendam o que isto tem haver com a célulatronco embrionária. Mas pelo que se nota, uma coisa está ligada a outra: quando observamos uma célula ao microscópio, dependendo da capacidade do instrumento poderemos ver as organelas celulares: membranas, complexos de golgi,retículos endoplasmáticos,mitocôndrias,etc...,se pudéssemos aumentar cada vez mais nossa capacidade de visão veríamos mais e mais até quem sabe as ínfimas partículas atômicas. Agora vejamos: se pudéssemos colocar o Universo em uma microscópio, em um certo ponto veríamos a nós mesmos, e vendo mais e mais chegaríamos novamente à partículas atômicas. Isto não lhes parece estranho?

Na década de 70, o prêmio Nobel da física, Erwin Schrödinger ${ }^{8}$, propôs-se a mostrar uma visão da física sobre a a vida concebida à maneira biológica. No início deste estudo denominado “O que é vida”, Schrödinger duvidava que a física e a química pudessem proporcionar uma visão exata da vida celular, na sua opinião a química orgânica e a biologia celular poderiam elucidar melhor a questão. A estrutura do DNA analisada por Schrödinger não era, ( e não é) uma estrutura que possua um comportamento padrão, como os cristais periódicos da física. Na visão de Scrödinger a cadeia de DNA era muito mais interessante que os tais cristais: frente ao DNA, os cristais periódicos eram estruturas

8 Schrödinger, E. O que é vida? O aspecto físico da célula viva.São Paulo: Unesp, 1992. 
apáticas e sem graça:

"Mesmo assim comparadas com o cristal aperiódico ( entenda-se DNA), elas são simples e sem graça. A diferença em termos de estrutura é do mesmo tipo que aquela entre um papel de parede comum, no qual o mesmo padrão é repetido indefinidamente numa periodicidade regular, e uma obra- prima de bordado, uma tapeçaria de Rafael, digamos, que não mostra repetições simples, mas antes um desenho elaborado, coerente e significativo traçado pelo grande mestre " (Schrödinger, 1977,p.19).

Schrödinger porém estava determinado a provar que um organismo biológico funciona conforme leis físicas precisas. De fato, a homeostasia de um organismo "vivo"se faz por meio de mecanismos celulares de controle hidroeletrolíticos que poderiam ser comparados aos mecanismos das máquinas criadas pelo homem.

No final de seu estudo, Schrödinger chegou à conclusão de que o funcionamento da matéria física não poderia ser reduzido às leis comuns da física: “(...) não sobre o fundamento de que exista alguma "nova força" ou o que quer que seja dirigindo o comportamento de cada um dos átomos de um organismo vivo, mas sim porque sua construção é diferente de qualquer outra coisa que já tenhamos testado em um laboratório de física.” ( Schrödinger, 1977,p. 87)

A Física apresentada por Schrödinger trabalha com leis que dizem respeito à ordem que se segue ao caos: não há precedentes na Física para o paradigma da "ordem gerando a ordem": “ A ordem encontrada no desenvolvimento da vida vem de uma fonte diferente. Parece que existem dois "mecanismos" diferentes pelos quais eventos ordenados podem ser produzidos: o "mecanismo estatístico", que produz "ordem a partir da desordem" e um novo, que produz "ordem a partir da ordem" (Schrödinger, 1977, p.91)

Segundo Schrödinger, a célula funciona como um "mini-escritório"onde um grupo de átomos trabalha de maneira afinada entre si e em relação ao meio ambiente: “(...) é um fato observacional simples que o princípio-guia em toda célula é corporificado em uma única associação atômica que existe em apenas uma cópia e é também um fato observacional que o princípio resulta na produção de eventos que são um paradigma de ordem.” (Idem, 1977,p.90)

A saída de Schrödinger foi admitir que, talvez, "a vida seja regida por um novo tipo de lei física, ou " lei não-física ou lei superfísica", a que ele chamou de "mecânica quântica do Senhor.’(Idem,p.95),(ou seria isto a causa primordial proposta por Platão?)

Então, se um respeitadíssimo físico admite que a matéria viva é regida por leis físicas desconhecidas, resta-nos, questionar duas coisas:como a Biologia vê a questão do início da vida e, não será isto um problema da técnica, da maneira como as ciências vem se desenvolvendo ao longo de quase trezentos anos? 


\section{2- O início da vida na biologia}

Se a vida para a Física principia na criação do Cosmos, para a Biologia a "vida" na concepção biológica dependeu dos processos evolutivos da Terra para se manifestar:

“(...) nosso planeta existe há cerca de 4,5 bilhões de anos, formas complexas de vida passaram a existir de uns 3,5 bilhões de anos, mas só há cerca de um e meio milhão de anos é que apareceram os primeiros proto- homens, seres humanos com andar ereto (homo erectus), e só há uns duzentos mil anos é que surgiram os homens como nós ( homo sapiens)." ( Küng, 2005).

Com estas afirmações $\mathrm{Küng}^{9}$ se refere à brevidade da vida do homem na Terra: comparados aos bilhões de anos de existência do Universo, a humanidade caminha sobre a Terra há apenas alguns segundos. Durante 3,5 bilhões de anos a impressão que se tem é a de que durante este período, a Terra constituiu-se em um gigantesco laboratório experimental de biologia: um extraterrestre cineasta que andasse por aqui teria filmado coisas que hoje conhecemos através dos trabalho da paleontologia, da arqueologia, da geologia.... Durante este período a Terra abrigou as mais diferentes formas de vida: desde as unicelulares amebas até o gigantes dinossauros, passando por uma enorme variedade de animais que mais pareciam o resultado de escabrosas experiências genéticas. Apesar das óbvias diferenças entre tais espécies, uma coisa tinham em comum: a vida!

Segundo McAlester ${ }^{10}$ :

“(...) a diferença entre um jequitibá e uma minhoca, ou entre um chimpanzé e uma bactéria são tão óbvias, que não é fácil conceber-se que tudo que é vivo constitui-se de apenas 6 elementos químicos predominantes. Êstes, por sua vez, formam uns poucos compostos químicos que se permutam entre si em um número infinitamente grande se substâncias. Os compostos principais formadores da matéria viva são os seguintes: água, carboidratos, graxas, fosfato de adenosina,proteínas e acido nucléico".( Mc Alester, ).

McAlester diz que tais elementos devem ter existido em abundância durante a formação do planeta. De acordo com a experiência de Müller, a carga elétrica sob a forma de relâmpagos sobre a atmosfera primitiva contendo amônia, metano e hidrogênio,poderia formar moléculas complexas análogas às formadas pelos sistemas vivos.

A experiência de Müller ${ }^{11}$ tinha por objetivo reproduzir artificialmente as condições da Terra quando do surgimento dos primeiros seres vivos. Explicar como o homem teria

9 KÜNG, Hans. Opus cit.,2004, p.123.

10 McAleSter, A. L., História Geológica da Vida. São Paulo: Edgard Blucher, 1971,p. 22.

11 McLESTER, A.L. Opus.cit.,pág.24 
surgido era uma outra questão. A partir do século XIX as ciências naturais se associaram à história, nascia a Teoria Evolucionista de $\operatorname{Darwin}^{12}$. De acordo com a Teoria Evolucionista organismos muito simples, unicelulares, em contato com seu meio foram se diferenciando (referimo-nos às mutações de ordem genética que acarretaram mudanças nas características funcionais e morfológicas destes primeiros organismos) e adaptando-se ao meio foram, "naturalmente", selecionados, demonstrando claramente, não exatamente a lei do mais forte (como pode parecer quando vemos um grande felino abocanhar um antílope), mas sim a do melhor adaptado ao ambiente, condição na qual algumas bactérias se incluem.

Sobre isto, Jay Gould ${ }^{13}$ tece as seguintes considerações: a teoria evolucionista de Darwin baseada na mutação e na seleção natural, mais especificamente desta última, levou à uma visão reducionista, na medida em que encorajou a " redução do cortejo geológico da história da vida no mínimo às maquinações temporárias dos organismos, se não à própria natureza físico química do material genético”( Jay Gould, “ O que é vida?” como um problema histórico, p. 42.)

A impressão que se tem é a de que realmente há um reducionismo, mas isto não passa de uma maneira de ver as coisas, culpa do método!

Olhando-se atentamente para a teoria de Darwin e para este primitivo organismo celular, será que não podemos ver os primórdios das idéias sobre célula-tronco?Afinal, o primeiro organismo que teria se diferenciado e dado origem a tantos outros pelos processo da mutação e da seleção natural não seria a célula-tronco primordial de todas as espécies?

De organismo em organismo, o processo evolutivo proposto por Darwin chegou ao homem e se pensamos numa suposta superioridade do homem sobre as condições naturais do planeta, a visão Darwinista sobre isto, nos trás a uma realidade bem dura pelo menos no que diz respeito ao corpo:

“ (...) os ossos humanos são idênticos aos seus correspondentes em um macaco, morcego ou baleia. Os cérebros humanos apresentam semelhanças com o orangotango,exceto pelas faculdades mentais. Pelos caracteres anatômicos do cérebro, o homem aproxima-se dos símios antropomorfos..." (Darwin ${ }^{14}$, A Origem do Homem)

Não contente com esta constatação, no capítulo I de “ A origem do Homem",Darwin apresenta duas figuras de embriões, uma do homem e a outra de cão mostrando uma notável semelhança, o que indicaria um possível índice de parentesco ancestral nesse estágio de desenvolvimento.

12 DARWIN. Origem das Espécies. São Paulo:Martin Claret, 2004,passim.

13 GOULD, Jay. O que é vida como um problema histórico.In: Darwin e os Grandes Enigmas da Vida. São Paulo: Martins Fontes, $2^{\mathrm{a}}$ ed,1999, p.42.

14 DARWIN. A Origem do Homem.Belo Horizonte:Itatiaia Editora, 2004. 
O embrião humano, resultado da fusão do espermatozóide com o óvulo constitui-se inicialmente em uma única célula . Mas não é possível pensar que as coisas em nível biológico se dêem automaticamente, mesmo a fertilização ${ }^{15}$ é um processo:

“ A fertilização é uma sequência complexa de "eventos moleculares coordenados que se inicia com o contato de um espermatozóide com um ovócito e termina com o embaralhamento dos cromossomos maternos e paternos na metáfase da primeira divisão mitótica do zigoto, um embrião unicelular." (Moore, K.2008)"

A fertilização só termina 24 horas após a ovulação. Poderíamos pensar na vida como processo metabólico realizado pela atividade celular, neste sentido poderíamos chamar "vivo" aquele único espermatozóide que fecundou aquele "vivo" óvulo, aí a vida do embrião seria apenas uma prolongação da vida das células que o geraram, não seria?Ao contrário, se pensarmos na morte biológica da célula, coisa que ocorre aos milhares todos os dias em todas as espécies, em um constante processo renovação celular tecidual, viveríamos ridiculamente em estado de luto pelos hepatócitos que se foram, pelas células neuronais que morreram depois daquele copo de vodca, pelas nossas células epidérmicas que a cada dia se renovam ( morrem e nascem) e a cada 30 dias temos uma nova pele!

Um dia o corpo morre. Mas este morrer não significa em um primeiro momento que tudo no corpo se constitua imediatamente em matéria morta, ao contrário, o corpo começa a morrer aos pouquinhos a partir do nascimento concluindo-se com o cessar das funções vitais determinadas pelos batimentos cardíacos e ausência de ondas cerebrais. $\mathrm{O}$ corpo como um todo leva um certo tempo para "morrer mesmo", o que permite a retirada de órgãos e a realização de transplantes. Então se a morte do corpo ( aqui falando-se de matéria) é um processo, porque o início da vida também não pode ser um processo?

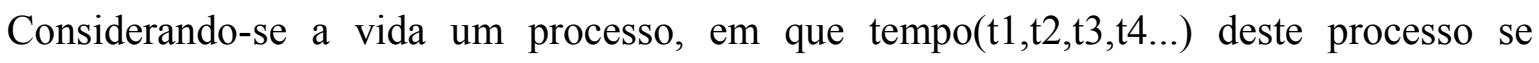
iniciaria a vida?

Assim como a Física amparada pela matemática e a lógica ainda não conseguiu provar com exatidão o início da vida cósmica, a Biologia, para definir a vida, se arrima em fatores condicionantes para definir a vida:tempo, ambiente,contingências de ordem física e química, condições reprodutivas,entre outras coisas. Vê-se como o conceito de início da vida é precário tanto na Física quanto na Biologia. Descobre-se então que o objeto de estudo em questão, é quase desconhecido,ou melhor dizendo, quanto mais se conhece em termos científicos a única certeza que se tem é a de que ainda falta muito para conhecer, tornando difícil o "encaixar" este objeto dentro dos padrões pré-determinados pela 
física,pela química,pela biologia.... Se aceitamos que a vida se inicia na fecundação,estamos lidando com as questões relativas ao corpo biológico aqui representado pela célula-tronco embrionária,nada se sabe saberia dizer sobre a alma,as questões relativa à alma não podem ser calculadas dentro dos limites estabelecidos pelas ciências modernas.

Temos assim dois caminhos a considerar: o primeiro caminho se delineia por aquele que define a vida apenas em seu aspecto material. Quanto a isto, a química, a física e a biologia e todos os patronos do ceticismo dariam conta de algumas explicações, mas não encontrariam o gene da irreverência, da inteligência, do caráter, da personalidade...Como seria bom e fácil se, ao olharmos o DNA de um embrião ao microscópio, pudéssemos dizer: - ah, será um ser humano bom, honesto,dotado de grandes capacidades intelectuais etc...Um segundo caminho seria aquele que considera o espírito como princípio que,ligado ao corpo the confere vida. Neste sentido, para se saber o início da vida deveria se perguntar:-Em que tempo $(\mathrm{t} 1, \mathrm{t} 2, \mathrm{t} 3 \ldots)$ da fecundação, o espírito se une ao corpo?

No "O livro dos Espíritos", um dos livros fundamentais do espiritismo kardecista há uma pergunta semelhante:

"Pergunta $344^{16}$ : Em que momento o Espírito se une ao corpo?Resposta: “ A união começa na concepção, mas só é completa no instante do nascimento. A partir da concepção o Espírito é designado para ligar-se a determinado corpo, e a este realmente se liga por um cordão fluídico, que se vai encurtando gradativamente, até o instante em que a criança nasce"

Dois quesitos importantes se encontram nesta resposta: 1- a ligação do espírito ao corpo ocorre em um processo que se inicia na concepção e termina no nascimento e 2- o Espírito é designado ( quem o designa para aquele corpo?).

Quanto à concepção cabe fazer uma distinção: a fertilização seja ela natural ou "in vitro" é um fenômeno diferente da concepção. Concepção no sentido acima citado se refere ao processo de nidação do embrião na parede do útero, pouco importando se a fertilização ocorreu extra, ou intrauterinamente. (Quando falarmos sobre a questão da técnica explicaremos melhor!)

Outra coisa que gostaríamos de ressaltar em relação a resposta dada pelo espiritismo é a condição de designação: o espírito é "designado" a um corpo, esta designação sugere um controle superior sobre qual espírito irá se ligar a tal corpo, o que também sugere a anterioridade da alma ao corpo, bem como o livre-arbítrio do próprio espírito.

16 KARDEC, A. O Livro dos Espiritos.São Paulo:OpusEditora,3aed1982,p.254. 
Percebe-se aqui uma dificuldade: a Biologia só dá conta dos processos da vida física, o método científico neste caso, não serve para elucidar as questões pertinentes ao espírito, neste aspecto, ou se aceita o que diz a religião sem qualquer questionamento ou, se a necessidade de se obterem respostas for de uma certa urgência, "encaixa-se a religião" nos padrões científicos, mas se a religião não cabe dentro dos padrões científicos, então será necessário procurar um outro método. Considerando-se o homem como ser dotado de corpo e alma, como se daria o início da vida para a religião e por que, para determinadas correntes religiosas a célula-tronco embrionária é considerada "ser humano"? Face à lógica religiosa a célula-tronco embrionária poderia ser considerada humana,ou o que há é uma confusão entre o conceito de vida biológico e o conceito de vida humana?

\section{3-Religião e célula-tronco embrionária- o início da vida}

\footnotetext{
“ Por religião, entendo uma propiciação ou conciliação de poderes superiores ao homem que se supõe, dirija e controle o curso de natureza da vida humana. Assim definida, a religião consiste em dois elementos,um teórico e um prático, ou seja, uma crença em poderes superiores ao homem e uma tentativa de propiciá-los e agradá-los. Dos dois, é claro que a crença vem em primeiro lugar,pois precisamos crer na existência de um ser divino antes de tentar agradá-lo. Mas, ao menos que a crença nos leve à prática correspondente, não é uma religião, mas tão somente uma teologia, nas palavras de São Tiago, “ a fé isoladamente,se não tiver atos é morta." Em outras palavras nenhum homem pode ser considerado religioso quando não pauta sua conduta, até certo ponto,pelo temor a Deus.Por outro lado, a mera prática, despojada de toda crença religiosa, também não é religiosa."

( Frazer, $\left.J^{17} ., 1982\right)$.
}

A definição de religião fornecida por Frazer em sua obra " O ramo de ouro" propõe que a religião se compõe de dois elementos: o primeiro e mais importante seria a crença em poderes superiores ao homem, ou seja, o homem deve acreditar que existe acima dele um ser superior que a tudo observa e controla e, em segundo lugar as ações deste homem crente devem ser pautadas por um temor a este ser superior ao qual ele chama de Deus.

Com o advento das células-tronco embrionárias e da possibilidade de sua utilização em pesquisas,acredita-se que o maior embate ocorra, no território das crenças religiosas. Questões como a fecundação e o início da vida, apresentadas ainda que sucintamente no início deste estudo quando da propositura da visão da Física e da Biologia, assim como aquelas referentes à morte têm na religião explicações, que, diga-se de passagem, 
apresentam talvez maior importância ao senso comum do que as explicações acadêmicas científicas, explicações estas que, por si só já bastam para muitos crentes, mesmo que não apresentem qualquer lógica. Intentando-se descobrir o que os religiosos das mais diferentes religiões do mundo pensam a respeito,sem qualquer pretensão de demonstrar todas as posições religiosas sobre o assunto ( tarefa que talvez demandasse anos de estudo de línguas e algumas viagens internacionais) verificamos que a pergunta sobre o início da vida,no sentido referente ao corpo físico do homem, foi repetida exaustivamente ${ }^{18}$ a chefes muçulmanos, monges budistas, chefes religiosos hinduístas, padres, espíritas, etc..., ocorre porém que cada religião se constitui em um universo único, repleto de símbolos e peculiaridades, ou como diria Campbel1 ${ }^{19}$ : “É preciso entender que cada religião é uma espécie de programa com seu conjunto próprio de sinais, que funcionam" (CAMPBELL,1993)

Assim, tentar entender plenamente as particulares razões de um budista, um hinduísta, um muçulmano talvez só seja possível vivenciando a própria religião, coisa que não se coaduna com o tempo que dispomos. De qualquer forma, a pergunta foi respondida e foram encontradas as mais variadas respostas. Portanto,propomos uma discussão, a respeito da visão, disposta na mídia, daquelas que são consideradas as maiores religiões do mundo em número de adeptos: o Cristianismo, o Islamismo, o Hinduísmo, algumas religiões chinesas ( taoismo, confucionismo entre outras ) e Budismo. Cabe aqui uma observação:por motivos que serão discutidos adiante deixaremos para abordar por último as questões pertinentes ao catolicismo,considerando neste caso sua maior expressividade em termos políticos no Brasil.

Em um site denominado Arresala ${ }^{20}$, dirigido à comunidade islâmica no Brasil, encontramos a seguinte pergunta, como se trancreve: "Com quantos dias que um feto pode ser considerado um ser vivo, e com quanto tempo ele recebe, o sopro da vida, ou melhor, seu espírito?"Citando o Alcorão Sagrado, o Sheik Al- Khazraji respondeu que, em conformidade com o que está disposto no capítulo 22 ( A Sura da Peregrinação)- Versículo 5, a nossa origem se inicia: a)Terra, (?), b) de uma gota seminal ( esperma), c) aderência ( o sangue coagulado e que se gruda), d) embrião configurado ( carne proteção), e)embrião, f) a entrada do espírito. Como pessoa leiga no que se refere aos assuntos islâmicos, e considerando a resposta do Sheik um tanto "esquemática",( conforme se encontrou no site) tornou-se necessária uma busca ao texto do Alcorão ${ }^{21}$, onde verificou-se o seguinte:

18 Para se provar o quão exaustivo esta pergunta foi repetida, basta acessar o "google" na Internet colocando-se na barra de buscas:religião e célula-tronco. (grifo nosso)

19 CAMPBELL, J. “ O Poder do Mito”.1993, cap.I,p.21

20 In:arresala.org.br.Acesso em 03/07/2008.

21 Texto do Alcorão disponível em:culturalbrasil.pro.br/alcorao1.htm 
“ Ó humanos, se estais em dúvida $\frac{(955)}{}$ sobre a ressurreição, reparai em que vos criamos do pó, depois do esperma, e logo vos convertemos em algo que se agarra e, finalmente, em feto, com forma $\left(\frac{956)}{}\right.$ ou amorfo, para demonstrar-vos (a Nossa onipotência); e conservamos no útero o que queremos, $\stackrel{(957)}{2}$ até um período determinado, de onde vos retiraremos, crianças para que alcanceis a puberdade. Há, entre vós, aqueles que morrem (ainda jovens) e há os que chegam à senilidade, até ao ponto de não se recordarem do que sabiam. E observai que a terra é árida; não obstante, quando (Nós) fazemos descer a água sobre ela, move-se e se impregna de fertilidade, fazendo brotar todas as classes de pares de viçosos (frutos).”

O texto sagrado muçulmano compara de maneira poética a imagem da terra, como elemento primordial da criação. Mas a terra, nessa visão passa por uma metamorfose e se transforma em esperma, que por sua vez gruda ( talvez na parede do útero da mulher?) e se transforma em feto,assim permanecendo por um certo período de tempo,determinado por Deus. De acordo com isto supõe-se que, talvez o Sheik Al- Khazraji tivesse a intenção de fornecer-nos uma resposta didática que permitisse a compreensão do processo de criação do homem, mais precisamente da geração de um bebê dividindo-o em etapas, mas, no final o Sheik ${ }^{22}$ diz: "A última etapa não é completa assim que entra em sua fase, mas sim necessita de um tempo para se transformar. Deus menciona no versículo que iremos aplicar algo de nós nele, significa que na última fase entrará o espírito. A mulher não sente um embrião ou seu bebê no útero desde o primeiro instante, mas sim apenas após mais ou menos 4 meses da entrada do espírito no embrião"

O que se observa é que, segundo a visão muçulmana, o tempo de "entrada do espírito no embrião" não é muito preciso. O Sheik diz que isto se daria na última fase, depois da formação do embrião, mas segundo a lei islâmica, uma mulher que venha a praticar o aborto intencionalmente, tanto no início ( antes do embrião formar-se), quanto por volta de quatro meses ( quando ela realmente sente o embrião) torna-se uma pecadora passível de uma pena pecuniária que se resume no pagamento de $3,529 \mathrm{Kg}$ de ouro, ( curiosamente a média de pêso com que os bebês nascem), tanto em um caso, quanto em outro. De qualquer forma, o islamismo condena o aborto intencional, e deixa subentendido que o espírito vive anteriormente ao corpo ( caso contrário ele não teria que entrar no corpo por volta do quarto mês para torná-lo vivo!).

Para o Sanatana- Dharma, conhecido popularmente como Hinduísmo, não há uma uniformidade de pensamento:um adepto desta religião, morador do norte da Índia, por exemplo, pode pensar completamente diferente de um outro adepto morador do sul. Não há uma única opinião religiosa,assim como não há na Índia, uma uniformidade legal, além disso, a própria lei( neste aspecto, aquela que se refere ao aborto) sofre influências da 
religião. No que se refere à pesquisa genética, o Hinduísmo não a proíbe, neste caso, a justificativa se encontra em um dos versos do Mahabarata, onde a esposa do rei dos Kauravas, Gandhari teria gerado uma bola de carne que permaneceu em gestação em seu ventre durante dois anos, sem que viesse a termo. Auxiliada por sua serva, Gandhari aborta a bola de carne que é cortada em 100 pedaços os quais foram, conforme o conselho de um rei, posteriormente plantados em um meio de cultura contendo "ghee"( uma espécie de manteiga) e água de fonte, dando origem aos cem filhos do rei. Outras narrações presentes no Mahabarata informam sobre a interferência do homem na criação de frutas, grãos, verduras e cereais. Também para o hinduísta são de grande importância as normas éticas contidas no Manusmriti ou Leis de Manu, segundo o qual, “(...)alguém só é considerado um ser humano, após passar pela realização de Samskaras ( ritos purificatórios, ou ritos de passagem) representados por: concepção, ritos de nascimento, corte de cabelo etc...." Em contrapartida, um outro princípio hinduísta diz que se deve agir de modo a produzir o menor dano possível para uma entidade viva, o que asseguraria a existência segura para alguns animais considerados inferiores, como por exemplo, o rato. Neste mesmo sentido atesta Swami Krishnapriyananda ${ }^{23}$, "as pesquisas que envolvam embriões de corpos humanos, e outras espécies, deverão ter um fim de bem-comum, onde o bom senso deverá estar presente".

Em relação ao Budismo, sua preocupação maior parece ser a morte ${ }^{24}$, ou melhor, com que se tenha uma "boa morte, do que com a vida. De fato, o budista prepara-se para a morte como um atleta. O Budismo vê a vida como um fluxo contínuo que às vezes pode assumir direção ascendente,se as ações de uma vida anterior foram boas, ou descendente, se os resultados das ações foram maus. Segundo o Budismo,o início da vida se daria no momento em que a consciência individualizada toma como suporte a união das células masculina e feminina, o que pode ocorrer tanto num corpo animal quanto num corpo humano. Na união do espermatozóide com o óvulo, o ser ( se assim podemos dizer) perde a sua consciência e passará a reestruturar uma nova consciência durante os nove meses de gestação, perdendo a memória da vida anterior. Não se pode afirmar, contudo, de acordo com esta visão, o momento exato em que o corpo passa a ter consciência, mas se esta consciência pode nascer em um corpo animal, ali, naquele animal poderá estar encarnado um parente próximo,um amigo querido, o que garante a preservação da vida animal seja de

23 In:hinduismo.org Acesso em : 30/07/2008.

24 Para o Budismo, a morte é vista "como uma passagem, uma etapa num processo bastante mais vasto que engloba nascimentos e mortes sucessivas, formas de existência variadas, vários registros da consciência humana. Neste contexto alargado, a morte deixa de ser um acontecimento único e traumático, o limiar do nada ou do mistério. Ela apresenta-se então como a dissolução do suporte físico e da formas menos sutis da consciência que está ligada ao corpo(...)" 
que espécie for. A visão Budista parece considerar a vida como um passagem importante,sendo que a morte nada mais seria do que um aspecto da própria vida. Para o Budismo todas as formas de vida devem ser preservadas,independentes estarem elas manifestadas em um corpo humano ou em um inseto, o que nos parece interessante é que, a visão de um fluxo contínuo de vida que se modifica momentaneamente com a morte parece significar aos budistas um conforto, ou talvez, até mesmo, uma certeza de que a morte não passa de um fenômeno da vida.

Deixamos por último, como já o dissemos e não sem um motivo,o Cristianismo, mais especificamente, entre as religiões cristãs,o Catolicismo. O Catolicismo acredita que a vida esteja presente já desde a fecundação do óvulo pelo espermatozóide, portanto, qualquer intervenção a partir disto significaria em um assassinato de um ser vivo. Como já o dissemos, a realidade brasileira se faz, na sua maioria de adeptos do catolicismo, e, visto que este foi o seguimento religioso que mais oposição ${ }^{25}$ fez à manipulação de célulastronco embrionárias para pesquisa, achamos por bem discutir as origens míticas da crença, ou seja, o que estaria por trás da idéia de se considerar que a vida, ou seja, a alma, está presente desde a fecundação?Observando-se bem,nenhuma religião, entre as anteriormente citadas parece afirmar que o início da vida se dê em tal ou tal tempo, não há precisão matemática. Muçulmanos dizem que até o quarto mês de gravidez, a mãe não sente o bebê, então, "sentir o bebê", pareceu-nos, no Islamismo ser o princípio norteador indicativo da ligação do espírito ao corpo, porém há uma certa contradição nessa idéia:a muçulmana que praticar o aborto em qualquer tempo, sem que haja motivos como risco de vida para ela ou para o bebê, poderá ser penalizada caso pratique o aborto, ou seja: não se conhece o início da vida, mas se penaliza o aborto. O Hinduísmo e o Budismo parecem semelhantes no que se refere a um fluxo contínuo da vida, demonstram um profundo respeito à vida quer ela se manifeste em um animal, quer ela se manifeste em homem. O Hinduísmo, por sua vez, encontra nas metáforas curiosas do Mahabarata,bem como nas leis éticas expressas no Código de Manu, a justificativa para a manipulação genética calcada no bem e no respeito respeito ao próximo.

Partindo-se da idéia que tais religiões se fundam na crença em um ser, ou seres superiores, sejam elas fixadas em Deus,Alá ou em várias divindades com atributos divinos de criação e destruição, como ocorre por exemplo, com os deuses hindus Brahma e Shiva no Hinduísmo. Assim não há porque questionar a existência de Deus ou algo semelhante 
no universo religioso. A pergunta que fazemos é por que, na via religiosa,principalmente no catolicismo, o início da vida embrionária ( ainda que não tenhamos uma definição concreta do que seja), é defendido com ferocidade? Admitindo-se a pré-existência do espírito, ou um fluxo contínuo de vida, como proposto pelo Budismo, por que tamanha preocupação com a morte? Em relação ao início da vida, só agora a biologia (genética) parece estar interessada em descobrir este limite, tanto quanto a religião, a vida ainda é definida pela ausência de morte.

Apesar de suas particularidades, as religiões em geral transmitem as mesmas idéias míticas em roupagens diferentes. Tamanha é a força do mito e de todos os seus símbolos que muitas vezes não se percebe o quanto se está imbuído disto,ou melhor, não se dá conta da quota mitológica presente nas próprias crenças. Como diria Campbell ${ }^{26}$ : “ Uma das grandes vantagens de ser educado no catolicismo romano é que você é ensinado a encarar o mito com seriedade, a deixar que ele atue em sua vida; você é ensinado a viver em função desses motivos míticos." (CAMPBELL.1993).Pesquisando-se o assunto, por diversas vezes presenciamos acaloradas discussões entre céticos e religiosos: os primeiros levantam a bandeira em defesa da pesquisa com células-tronco embrionárias calcados nas razões éticas do bem comum, os últimos, defendem a vida , "apenas por ser vida(?)", mesmo que não tenham uma pálida idéia do que isto signifique. Constata-se porém, que o mito ( aqui nos referimos sempre às idéias míticas presentes nas crenças) parece fazer parte de uma dimensão inconsciente atávica e ancestral.

Observando-se o ferrenho debate entre padres católicos e cientistas,nota-se que o argumento católico parece ter- se perdido em si mesmo. Admitindo o "homicídio" ( se é que isto seja possível) da célula-tronco embrionária, ressalte-se, gerada fora do útero, o catolicismo desconsiderou a gestação, ainda necessária para gerar um filho, pois reconhece a ciência, não há possibilidade, ainda, de geração de bebês humanos fora do útero. Em segundo lugar: se a Igreja Católica esqueceu-se da gestação em seus argumentos, aboliu também a figura da mãe e a sacralidade do casamento. Em terceiro lugar, transformou Deus em uma figura ociosa,(“deus otiosus”), aquele mesmo do mecanicismo que criou o mundo e saiu de férias, visto que, se cabe a Deus determinar que tais e tais espíritos, ou almas animem um determinado corpo, o que faria um espírito em uma célula-tronco se ela estiver destinada a se transformar em um órgão ou tecido de outro organismo?Defrontamonos novamente com a resposta dada pelo espiritismo quanto à designação anterior dos espíritos se unirem a determinados corpos por ocasião da concepção. Em quarto lugar, o

26 CAMPBELL,J.O Poder do Mito.São Paulo: Palas Atena, 1993, capI, p.10. 
catolicismo caiu em contradição em relação aos seus próprios preceitos, deixando de lado a compaixão para com os próprios homens. Que se esclareça desde já, a não intenção de uma crítica vazia e despropositada mas sim, antes de mais nada, que o que se pretende discutir sirva para que uma religião tão influente reveja e atualize seus conceitos.(Parece-nos que o catolicismo assim se posicionando cai na armadilha da "zona límbica" (grifonosso) por Hannah Arendt quando se refere a ausência do pensar quando da realização de atos de maldade por omissão.)

Analisando-se a questão do ponto de vista mítico, verificou-se, entre outras coisas que as religiões, em geral,tem suas crenças posicionadas no território do fabuloso e sagrado mito da criação. Na verdade, estudando-se os mitos, facilmente se verifica que a criação do homem não passa de uma cosmogonia repetida em menor escala, daí a sacralidade da vida:a criação do homem no mito aparece profundamente atrelada à criação anterior do planeta (como dissemos, talvez aí se encontrem as melhores alegorias e justificativas religiosas para a preservação do meio ambiente).Mas não pertence à Física a missão de descobrir o início do Cosmos?Também, da mesma maneira que o nascimento, o nascer com vida, se constitui na esfera do sagrado, o mesmo ocorrendo com a questão da morte, em suma, na via religiosa, a a vida inteira parece passar em estado de sacralidade.

\section{1.-A célula-tronco embrionária vista como corpo humano- As cosmogonias planetária e humana- A criação do homem como repetição da criação do mundo}

No início deste estudo propusemos a visão da Física a respeito do início da vida. Ironicamente a religião parece seguir os mesmos passos da Física, com um pouco mais de poesia e encantamento. Perguntando-se à religião:Como se faz um corpo humano? De que matéria e de que maneira se constrói um corpo? Quais seriam as respostas?

Todos nós, alguma vez na vida devemos ter brincado ou podemos ter observado uma criança brincar com massa de modelar. Não raro, a criança faz da massinha um boneco que será o protagonista de algumas aventuras imaginárias, assim, o bonequinho ganha nome,( geralmente o do personagem preferido dos desenhos animados), profíssão ( bombeiro, policial, médico...), algumas vezes sofre nas mãos de algum bandido (o boneco do amigo), se machuca, se alimenta, parece vivo. É claro que por trás do boneco há uma 
mão infantil coordenando todos os seus atos, de qualquer maneira, nesta singela brincadeira, a criação da mente infantil parece conferir vida ao simples boneco.

Recordo-me também de que, no final da década de 90, um certo joguinho virtual japonês tornou-se mania no mundo todo, e neste caso, nem os adultos ficaram imunes. Tratava-se do "tamagotchi". Este joguinho consistia em um tela pequena, mais ou menos do tamanho da palma da mão de uma criança entre oito e dez anos, onde um animalzinho simpático nascia de um ovo e cabia à criança, dona do brinquedo, cuidar para que o bichinho ( a princípio uma bolinha com expressões faciais) crescesse e adquirisse então uma forma final de um animal conhecido. Sendo assim, o brinquedo apitava toda vez que o bichinho queria comer, dormir, passear, brincar e a criança deveria satisfazer todas estas necessidades de maneira equilibrada, caso contrário o personagem poderia "adoecer e morrer",ou se transformar em um monstrinho. Naquela época pude observar que a "maternidade do tamagotchi”" parecia atrair mais as meninas, que, mesmo já entrando em idade adulta levavam nas bolsas universitárias, junto aos códigos e doutrinas jurídicas, o tal joguinho. Lembro-me também que o que mais chamava a atenção na época era o fato de que, quando o bichinho morria, ( por um descuido do dono ou por programação virtual), seus donos ficavam tristes. Neste ponto, a idiossincrasia da situação me fazia perguntar: por que além das crianças, também os adultos pareciam decepcionar-se?

Passados onze anos, ( a febre do jogo virtual tamagotchi ocorreu no Brasil por volta de 1997) e após vários séculos de pesquisa científica nos encontramos com as polêmicas questões em torno da célula-tronco embrionária. Para alguns é organismo vivo passível de todas as sensações e condições de um ser humano constituído. Para outros, se caracteriza em forma biológica capaz de gerar tecidos e corrigir doenças genéticas ou condições mórbidas adquiridas acidentalmente. Para os primeiros, aqueles que acreditam na vida contida na célula-tronco,(aqui nos referimos especialmente ao pensamento religioso difundido pela igreja católica) esta se constitui em organismo sagrado e como tal sua utilização de forma terapêutica se constituiria em profanação da vida humana em si considerada Criação Divina. Para os últimos, a célula-tronco embrionária se traduz em esperança de cura de doenças que até então só poderiam ter seu avanço estacionado temporariamente através de cuidados e medicamentos paliativos. Originadas a partir de um “ovo", muitos lhes conferem status humano, mesmo que nunca venham a ser implantadas em um útero materno. Como os personagens mencionados nos parágrafos anteriores, a célula-tronco embrionária para a visão religiosa surge como algo cheio de vida, ou pelo menos com a vida congelada (o que cientificamente se dá por um estacionamento da 
divisão celular) por um certo lapso de tempo. Diante da situação indaga-se: Não seria esta idéia semelhante ao exercício lúdico das crianças? Obviamente não pretendemos comparar células, matéria de origem humana, com massinhas de modelar e bichinhos virtuais, o que nos intriga é o poder da criação. A própria palavra criar parece estar imbuída de vida e o que é criado parece atrair a idéia de vida inerente. Não se trata ainda, neste momento de discutir sobre a possibilidade vital como ser humano da célula-tronco embrionária, importa-nos por ora tentar demonstrar a razão pela qual tantos religiosos acreditam que a utilização de tais células para pesquisa científica significa atentar contra à dignidade da vida humana.

Ainda, em relação aos religiosos, de onde se originaria a idéia do sagrado atribuído às células-tronco? Por que a religião ( aqui me refiro a certas linhas do pensamento cristão) insiste no aspecto de que a utilização, ainda que terapêutica destas células, incorreria em assassinato? O que há por trás da idéia de vida humana atribuída a estas células?

Para entender a razão pela qual o pensamento religioso se coloca de maneira tão contundente propõe-se uma breve discussão sobre mitos. Segundo a definição fornecida pelo “ Random House Dictionary ${ }^{27}$ : “ a story or beliefe that attempts to express or explain a basic truth; an allegory or parable.” pode-se inferir que, de maneira alegórica, metafórica, os mitos parecem carregar consigo a sensação de uma verdade presente em conteúdos inconscientes que venceram e vencem até hoje a barreira do tempo e do espaço. Por isto, mesmo que ainda não se possa explicar o modo como a vida se manifesta em um corpo,ou como um corpo se torna vivo, a impressão que se tem é a de que, com isto, se penetra em território divino. Então, como poderia o homem se atrever a mexer na obra do " Criador”? Pela própria via mítica sabe-se que a profanação do sagrado sempre resultou em castigo e punição, afinal, de acordo com um famoso mito,por determinadas "artes" de Adão e Eva, estamos todos "penando" aqui neste mundo de muito trabalho e dor.

Segundo Mircea Eliade ${ }^{28}$ :

“ Há mais de meio século,os eruditos ocidentais passaram a estudar o mito por uma perspectiva que contrasta sensivelmente com a do século XIX, por exemplo. Ao invés de tratar, como seus predecessores, o mito na acepção usual do termo, i.e, como "fábula", "invenção", "ficção", eles o aceitaram tal qual era compreendido pelas sociedades arcaicas, onde o mito designa, ao contrário, uma "história verdadeira (...) De fato, a palavra é hoje empregada tanto no sentido de "ficção" ou ilusão", como no sentido - familiar sobretudo aos etnólogos, sociólogos e

27 GORDON, Raim e Rivca. " Heidegger on Truth and Myth - A rejection of Postmodernism Phenomenology \& Literature: Peter Lang Publishing. New York. 2006-p.2.

28 ELIADE, Mircea.Mito e Realidade.São Paulo:Perspectiva, 6ªd.p.7,8. 
historiadores de religiões- de "tradição sagrada, revelação primordial, modelo exemplar"

Mircea Eliade não entende o mito como ilusão, procura basear seus estudos no mito produzido em sociedades onde ele é tratado como "vivo", no sentido de que fornece os modelos para a conduta humana, conferindo,por isso mesmo, significação e valor à existência". Para Eliade ${ }^{29}$ :

"o mito conta uma história sagrada, ele relata um acontecimento ocorrido no tempo primordial, o tempo fabuloso do "princípio". " Em outros termos o mito narra como, graças às façanhas dos Entes Sobrenaturais, uma realidade passou a existir, seja uma realidade total, Cosmo, ou apenas um fragmento: uma ilha, uma espécie vegetal, um comportamento humano, uma instituição. É sempre, portanto, a narrativa de uma "criação": ele relata de que modo algo foi produzido e começou a ser".

Analisando os mitos, verificamos que as explicações para a criação do homem se encontram na maioria das vezes atreladas aos mitos cosmogônicos da formação da Terra. Como propõe Eliade ${ }^{30}$ :

"Em relação aos Vedas, parecem existir quatro tipos de cosmogonias, sendo: "1) criação pela fecundação das Águas originais; 2) criação pelo despedaçamento de um Gigante primordial, (no caso dos hinos védicos, este personagem tem o nome de Purusa); 3) criação a partir de uma unidade-totalidade, simultaneamente ser e não ser; 4) criação pela separação do Céu e da Terra".

Em termos mitológicos e no que se refere a este estudo, interessa-nos, principalmente o mito de criação resultante da fecundação das águas originais e o mito referente ao despedaçamento de um Gigante Primordial. Seguindo esta proposta temos o seguinte: “ No célebre hino do Rig Veda, X, 121, o deus imaginado como Hiranyagarbha ( o "Embrião de Ouro") plana sobre as Águas; ao penetrá-las, fecunda as Águas que dão à luz o deus do fogo, Agni ( estrofe 7)"31 .Como se pode perceber, anuncia-se assim a idéia de sacralidade do embrião como elemento fundamental originador de tudo o que existe.

A segunda forma de criação, como dito por Eliade ${ }^{32}$, é aquela que se refere ao desmembramento de um gigante, desta forma:

"O Gigante primordial Purusha ("o Homem") é representado ao mesmo tempo como totalidade cósmica e Ser Andrógino.(...) os deuses sacrificam o "Homem": do seu corpo despedaçado emanam os animais, os elementos litúrgicos, as classes sociais, a Terra, o Céu, os deuses: Sua boca transforma-se no Brâmane, de seus braços surge o Guerreiro, de suas coxas o Artesão, de seus pés nasce o Servo...( e se nos permite,

29 Ibidem, p.11.

30 ELIADE,M. História das crenças e das idéias religiosas. Rio de Janeiro: Zahar Editores, $2^{\mathrm{a}} \mathrm{ed}, 1983$, tomo I, vol2,p.51-52.

31 In: www.hinduismo.org. Acesso em 30/07/2008.

32 Eliade, M.Opus cit., p.52. 
nasce também toda a justificativa religiosa hinduísta para o sistema de sociedade de castas).

Segundo Eliade ${ }^{33}$ :

“ A Criação não pode processar-se senão a partir de um ser vivo que se imola: um Gigante primordial, andrógino, ou um Macho cósmico, ou uma Deusa- Mãe, ou uma Rapariga mítica. Precisemos que esta "Criação" se aplica a todos os níveis da existência:pode tratar-se da criação do Cosmos, ou da Humanidade,ou somente de uma certa raça humana, de certas espécies vegetais ou de certos animais."

O esquema mítico é o mesmo: nada pode ser criado se não for pela imolação, pelo sacrifício,assim,o gigante Ymir (originado a partir da lambidas da vaca sagrada, Audumbla sobre um bloco de gelo) é sacrificado pelos filhos de Bor e Bestla ( que, no mito nórdico são as divindades conhecidas pelos nomes de Odin, Vili e Ve): “(...) com o corpo morto de Ymir formam "a terra,com seu sangue os mares, com seus ossos as montanhas, com seus cabelos as árvores, com seu crânio o céu e com seu cérebro as nuvens carregadas de neve e granizo" ( se este mito fosse contado por indígenas brasileiros, provavelmente o cérebro daria origem a um céu azul e estrelado...)

Parece-nos então que a força do mito paulatinamente se intensifica: temos a princípio a figura do embrião, como idéia originária de fecundação do mundo e em segundo a figura do homem gigante: sagrado por ser divino e sagrado por ser destinado ao sacrifício necessário à criação.

\section{2-Homens gerados por deuses - a noção de parentesco cósmico com a criação da Terra e a noção de gestação humana}

Alguns mitos demonstram a profunda ligação entre o surgimento da terra e o surgimento do homem. Gostaríamos de evidenciar, neste aspecto dois tipos de mitos: No primeiro tipo, uma divindade cria o mundo e de algum material que compõe este mundo, ( geralmente a terra ou barro)a mesma divindade faz o homem. No segundo tipo, a própria Terra aparece antropomorfizada sendo denominada "Terra-mãe"sugerindo a necessidade da gestação para a geração do homem.

Encontram-se entre os mitos em que a criação surge por obra e vontade de uma divindade, um dos mitos mais conhecidos pelos religiosos, ou seja aquele que podemos exemplificar por dois modelo:

“ (...)primeiro há o caos, sobre o qual age Deus, ou qualquer outra divindade por vezes

33 Eliade, M. Mitos, Sonhos e Mistérios. São Paulo: Edições 70, p.154 
semelhante, realizando a separação entre luz, trevas, céu,terra e águas, fazendo surgir plantas e animais e só por último a figura do homem. Assim:

Sendo a parte ígnea a mais leve, espalhou-se e formou o firmamento; o ar colocou-se em seguida, no que diz respeito ao peso e ao lugar. A terra, sendo a mais pesada, ficou para baixo, e a água ocupou o ponto inferior, fazendo-a flutuar. Nesse ponto, um deus-não se sabe qual-tratou de empregar seus bons ofícios para arranjar e dispor as coisas na Terra. Determinou aos rios e lagos seus lugares, levantou montanhas, escavou vales, distribuiu os bosques, as fontes, os campos férteis e as áridas planícies, os peixes tomaram posse do mar, as aves, do ar e os quadrúpedes, da terra. Tornara-se necessário, porém, um animal mais nobre, e foi feito o Homem.( BULFINCH ${ }^{34}$,T. 1998).

O mesmo pode-se constatar na "Gênesis" judaica: Deus ordena o caos, separa os elementos naturais, fogo, terra, água e ar, cria a flora e a fauna e depois de tudo isto, quase ao final, cria o homem, semelhante à imagem da criança envolvida com a brincadeira de massinha: "Formou pois o Senhor Deus ao homem do limo da terra, e assoprou sobre o seu rosto um assopro de vida, e recebeu o homem, alma e vida”. ( Gen, 2,4) ${ }^{35}$.

Apesar da incrível semelhança, Bulfinch não se refere ao conhecido mito bíblico da criação. De fato, o trecho acima descreve a formação do mundo a partir do Caos por um deus desconhecido na perspectiva mítica grega., como continua a propor o mito: A partir daí, forças naturais representadas pelos Titãs se encarregarão do controle dos cinco elementos naturais ( Gaia - Terra, Urano- águas, etc...), caberá a dois titãs, Prometeu e Epimeteu, a criação do homem, como se verifica: "Prometeu tomou um pouco de terra e misturando-a com água, fez o homem à semelhança dos deuses. Deu-lhe o porte erecto, de maneira que, enquanto os outros animais têm o rosto voltado para baixo, olhando a terra, o homem levanta a cabeça para o céu e olha as estrelas ( Bulfinch, T. 1998).

Mas, de acordo com os mitos citados o que se observa é que tudo provém da criação divina, mesmo que a figura humana não esteja personificada na natureza como veremos adiante, nota-se que a vida em geral é uma atribuição divina: ( soprou em seu rosto um assopro de vida...). Outra característica é que a sobrevivência do homem está ligada à toda vida natural ${ }^{36}$ : “ Tomou pois o senhor Deus ao homem, e pô-lo no paraíso das

34 BULFINCH,Thomas. O livro de Ouro da Mitologia. 2aed.São Paulo: Ediouro, 1996. Cap.II, p.19-20.

35 Bíblia Sagrada. Rio de Janeiro: Enciclopédia Britânica, 1980,p.2.

36 Talvez se encontrem nestas histórias o argumento religioso necessário à preservação ambiental, afinal nunca se falou tanto sobre a preservação do meio ambiente, sendo que a maioria dos programas com este objetivo colocam finalmente o homem como co-participante de um processo natural. 
delícias para ele o hortar e guardar. E deu-lhe esta ordem, e lhe disse: Come de todos os frutos das árvores do paraíso" ( Gen,2, 15-16). ${ }^{37}$

Como diria Eliade ${ }^{38}$ :

"Para viver no Mundo é preciso fundá-lo- e nenhum mundo pode nascer no " caos" da homogeneidade e da relatividade do espaço profano. A descoberta ou a projeção de um ponto- fixo- o "Centro"- equivale `a Criação do Mundo e não tardaremos a citar exemplos que, mostrarão, de maneira absolutamente clara, o valor cosmogônico da orientação ritual e da construção do espaço sagrado". (Eliade,M. 2001)

Eliade quer dizer com isto que, a vida humana como a concebemos só seria possível mediante uma série de elementos já pré-existentes, estabelecendo-se assim a sacralidade da criação, desde a concepção do espaço natural até o homem. Daí a argumentação aparentemente redundante e descabida por algum correntes do pensamento em defesa da vida, porque é vida, vida porque é vida, etc...Mas o que é vida?

Mais adiante Deus cria a mulher a partir de uma costela de Adão e neste ponto o mito nos leva à observar que: o homem é criado do limo da terra ( material que existia na natureza criada anteriormente por Deus), mas porque a mulher não foi criada da mesma forma? Em sua composição, se podemos dizer desta forma, Deus utiliza material biológico humano vivo, o que nos leva a pensar tanto na criação a partir de tecidos já existentes ( e não é também sobre isto que tratará este trabalho?), afinal um ser humano vivo, Adão, permite que se gere uma nova vida, Eva e aí o argumento se fecha: vida gera vida! Mas os religiosos se esquecem que a atribuição de alma e vida, como diz o próprio texto, é atributo de Deus: "o sopro da vida."

Outra característica importante a se ressaltar destas duas idéias é a de que não há gestação. Tanto a criação humana feita por Prometeu quanto por Deus resulta em um homem já crescido, constituído, não há presença da mãe, não há gestação.

Retomando-se a idéia de sacrifício proposta pela Edda ${ }^{39}$ escandinava, também Adão não teria sofrido um pequeno sacrifício na criação de Eva? Conta que Deus o havia feito dormir antes de lhe arrancar uma das costelas, atos que se assemelham à atividade médica de anestesiar e operar no sentido cirúrgico. Sem nos determos em julgamentos,mais uma vez percebemos que o homem imita, ou pelo menos tenta imitar a atividade divina, falta- lhe o dom da onisciência, um conhecimento total e absoluto de todo o processo de criação. 
Sobre os mitos citados podemos também perceber que, além do fato do homem ser criado por entidades sobrenaturais, ele sempre é criado adulto,pronto, crescido e capaz de assumir obrigações. Nas duas idéias míticas citadas não há embriões ou, nem mesmo, o homem surge de um ovo.

Em relação à gestação humana, como dissemos anteriormente, surge clara e nítida a Terra vista de forma antropomórfica, como diria Eliade ${ }^{40}$ :

"Encontra-se esta imagem em todas as partes do mundo, sob inúmeras formas variantes, É a Terra Mater ou a Tellus Mater, bem conhecida das religiões mediterrânicas, que dá nascimento a todos os seres. "É a Terra que cantarei" lê-se no hino homérico à Terra, " mãe universal de sólidas bases, avó venerável que nutre em seu solo tudo o que existe".(Eliade,M. 2001)

Também em Eliade ${ }^{41}$, alguns mitos americanos revelam que:

“ os primeiros homens viveram certo tempo no seio de sua mãe, isto é, no fundo da Terra, em suas entranhas. Lá, nas profundezas telúricas, levavam uma vida meio-humana: eram de certo modo embriões ainda imperfeitamente formados. É, pelo menos, o que afirmam os índios lenni lenape ou delaware, que habitavam outrora a Pensilvânia; segundo seus mitos, o Criador, embora já tivesse preparado para eles, na superfície da Terra, todas as coisas de que gozam atualmente, tinha decidido que os homens ficariam ainda algum tempo escondidos no ventre de sua Mãe telúrica, para que se desenvolvessem melhor, para que amadurecessem."(Eliade, M.).

Utilizando-nos deste mito, percebemos que tanto a figura da mãe, quanto a idéia de gestação estão presentes e mais uma vez chegamos ao ponto de comparação: sendo implantada em um ventre materno, talvez ( veja bem, talvez), a célula-tronco embrionária venha a se transformar em um feto que gestado, virá (ou não) a nascer. Descartada a possibilidade de vida humana extrauterina ( como discutiremos adiante), nota-se que o argumento religioso católico manca, falseia, joga-se fora a presença "ainda" necessária da mulher e da gestação. Mas, pelo que se pode inferir,muitos mitos sacralizaram a mulher e todos os eventos relacionados com o nascimento, como se vê em Eliade ${ }^{42}$ :

"A mulher relaciona-se,pois, misticamente com a Terra; o dar à luz é uma variante, em escala humana, da fertilidade telúrica. Todas as experiências religiosas relacionadas com a fecundidade e o nascimento têm um estrutura cósmica. A sacralidade da mulher depende da santidade da Terra. A fecundidade feminina tem um modelo cósmico: o da Terra Mater; da Mãe universal."(Eliade, 2001)

De acordo com Eliade $^{43}$, a figura do ovo aparece no Tibet com a finalidade de

40 Eliade,M. O sagrado e o Profano- A essência das religiões. São Paulo: Martins Fontes, 1ªed., 2001, p.117

41 Ibidem

42 Eliade, M.Opus cit. p.120-121.

43 Eliade, M. História das Crenças e das Idéias Religiosas.Rio de Janeiro: Zahar Editores, Tomo I, 
explicar a origem do mundo bem como das grandes famílias e dinastias tibetanas, como se segue:

" Da essência dos cinco elementos primordiais, nasceu um grande ôvo... Dezoito ovos saíram da gema desse ovo. O ovo do meio, dentre os dezoito ovos, um ovo concóide, separou-se dos demais. Esse ovo concóide desenvolveu membros, e depois os cinco sentidos, tudo perfeito, convertendo-se num jovem de tão extraordinária beleza, que parecia a concretização de todos os desejos ( yid la smon). Por isso, foi chamado de rei Ye-smon.A rainha Tchu-lchag, sua esposa, deu à luz um filho, capaz de se transformar por meio de magia, Dbang-Idan”.( Eliade ${ }^{44}, \mathrm{M}$.)

Outra questão a ser levantada é a do nascimento sem mãe. No mito judaico-cristão Adão é feito de argila por obra e vontade divinas. Criado pelas mãos de um Deus, sem participação de um útero feminino. Neste mito não há gestação .De fato, gestar e parir um filho são coisas que só aparecem depois da expulsão do paraíso.

Curiosamente porém, a figura feminina toma parte na criação do homem, nos mitos contados em outras comunidades arcaicas. Assim, de acordo com os índios americanos das etnias lenape ou delaware, os primeiros homens viveram um certo tempo no seio de sua mãe, isto é,no fundo da Terra, em suas entranhas. Lá nas profundezas telúricas levavam uma vida meio-humana: eram de certo modo embriões ainda imperfeitamente formados. Talvez um pouco mais precisos em relação ao evolucionismo proposto por Darwin, tais índios parecem, ainda que alegoricamente, conhecer a evolução humana, quer seja em relação ao planeta, quer seja em relação à vida intra-uterina, melhor do que a religião responsável por sua conversão nem sempre pacífica. Para eles, o homem é primeiramente um germe, um embrião, sofre uma gestação e nasce,é parido pela Terra. Neste sentido Eliade $^{45}$ nos recorda de um certo mito navajo, como refere:

"De momento, recordemos ainda alguns mitos sobre a gestação e o parto. Em língua navajo, a Terra chama-se Naestsán, literalmente, "a mulher horizontal" ou a "mulher deitada". Segundo eles, existem quatro mundos subterrâneos sobrepostos; os Zuñi chamam a esses mundos as quatro matrizes da Terra. É lá na mais profunda matriz da Terra, que os homens viveram no princípio. Emergiram à superfície através de um lago ou de uma nascente, ou, de acordo com outras tradições, trepando ao longo de uma vinha (seg. os Mandau) ou de um junco ( seg. Os Navajo)... ( ...)osGêmeos ( talvez a divindade?) trouxeram com eles à superfície um certo número desses homens subterrâneos; é deles que descende a humanidade atual. É por essa razão, prossegue o mito, que o recém nascido se alimenta exclusivamente de "vento" até ao momento em que a corda invisível é cortada; só então pode começar a absorver leite e uma alimentação muito ligeira, e mesmo assim com uma grande dificuldade."

vol2,passim

44 ELIADE,M.Mito e realidade. São Paulo:Ed.Perspectiva, 6 ed., p.26.

45 ELIADE, M. Mitos, Sonhos e Mistérios. Coleção Perspectivas do Homem. Edições 70.p.136. 
Ainda em Eliade ${ }^{46}$ :

"Vê-se em que sentido este mito liga a ontogênese à filogênese: a condição do embrião e do recém nascido é comparada à existência mítica da espécie humana no seio da Terra ; cada criança repete na sua condição pré-natal, a condição da Humanidade primordial. A assimilação da mãe humana à Grande - Mãe telúrica é completa. Compreender-se-á melhor esta simetria entre a condição infantil e a antropogonia- ou para utilizar vocabulário científico: entre a ontogênese e a filogênese.”

De acordo com os estudos feitos por $\operatorname{Eliade}^{47}$, a mãe humana é apenas a representante da Grande Mãe telúrica. Como diz: “ A Mulher relaciona-se pois, misticamente com a Terra; o dar à luz é uma variante, em escala humana da fertilidade telúrica. Todas as experiências religiosas relacionadas com a fecundidade e o nascimento têm uma estrutura cósmica. A sacralidade da mulher depende da santidade da Terra. A fecundidade feminina tem um modelo cósmico: o da Terra Mater, da Mãe Universal.”

A mãe humana repete, imita o ato primordial de aparição de vida na Terra. Desta maneira chegamos à noção do sagrado atribuída ao nascimento e por semelhança à célulatronco embrionária.

Ocorre porém que, este embrião ou célula-tronco embrionária, pode vir ou não a ser gestado, pode vir ou não a se desenvolver,mas esta última condição só se tornará possível com o suporte de um útero materno, sem isto, ela não se tornará um bebê e ainda assim, mesmo que implantada, talvez ela não venha a nascer, corroborando muitas vezes nos abortos ditos naturais ou espontâneos. Penso que neste aspecto, a figura materna como geradora desaparece perante os redundantes argumentos religiosos de salvar a "vida porque é vida". Para se estar de acordo com isto, toda célula-tronco deveria ser implantada em algum útero, coisa que pode ferir direitos, vontades e condições das mulheres quando tratadas como indivíduos.

Retomando-se a noção do sagrado, percebe-se também que nem sempre o sagrado se define pela beleza da criação. Em várias noções mitológicas o sagrado se faz pelo sacrifício e pela dor. Como dito anteriormente, a costela arrancada de Adão teria feito nascer Eva, o desmembramento de Ymir ( o gigante nórdico) teria formado o mundo, o corpo do Cristo sacrificado surge continuamente nos ritos eucarísticos do catolicismo, porém, narram os mitos, segue-se o sacrifício de um renascimento, de uma nova criação, como diz Eliade ${ }^{48}$ :

“ A Criação não pode processar-se senão a partir de um ser vivo que se

46 ELIADE,M. Mitos, Sonhos e Mistérios.São Paulo:Edições 70, cap.VIII, p.136.

47 ELIADE,M. O Sagrado e o Profano- A essência das Religiões.São Paulo: Martins Fontes, 1ªed.2001.

48 ELIADE, M.Mitos, Sonhos e Mistérios. São Paulo: Edições 70,p.154. 
imola: um Gigante primordial,andrógino, ou um Macho cósmico, ou uma Deus-Mãe, ou uma Rapariga mítica. Precisemos que esta " Criação" se aplica a todos os níveis da existência : pode tratar-se da criação do Cosmos, ou da Humanidade, ou somente de uma certa raça humana, de certas espécies vegetais ou de certos animas. O esquema mítico é o mesmo: nada pode ser criado se não for pela imolação,pelo sacrifício. É assim que determinados mitos nos falam da criação do mundo a partir dum corpo de um mesmo Gigante primordial: Ymir, P'an- ku, Purusha." ( Eliade,M.).

Infere-se disto que a vida nasce de outra vida que se sacrifica. Uma certa tradição encontrada entre os "khonds", na Índia, descreve que, uma vítima voluntária ( chamada meriah) apresentava-se voluntariamente para um sacrifício. Durante alguns dias ela era homenageada e identificada com a divindade a qual seria oferecida em sacrifício. Depois disso, era então drogada com ópio,estrangulada e retalhada em pedaços. Os pedaços eram distribuídos pelas aldeias e enterrados nos campos.

Deixando-se de lado o terror da cena, vê-se que o ciclo mítico se fecha: a mesma terra que dá origem ao homem, pede o seu sacrifício para gerar vida novamente. Como diz Eliade $^{49}$ :

“ Não se deve perder de vista uma coisa: se a Terra se torna Deusa da Morte, é justamente porque é encarada como matriz universal, como fonte inesgotável de toda a criação. A morte por si própria não é um fim definitivo, não é o aniquilamento absoluto, e assim é por vezes concebida no mundo moderno. Morto é comparável à semente que, enterrada no seio da Terra-Mãe, dará nascimento a uma nova planta. Assim, pode se falar duma visão optimista da morte,porque ela é considerada como um regresso à Mãe, uma reintegração provisória no seio materno. É por isso que encontramos, no neolítico o enterramento em posição embrionária: os mortos são depostos na Terra na atitude de embriões, como se se esperasse que regressassem incessantemente à vida."

No mesmo sentido propõe Joseph Campbel1 ${ }^{50}$ :

"Outra idéia associada às florestas tropicais é que da decomposição surge a vida. Eu vi maravilhosas florestas de pau-brasil, com grandes, imensas toras de árvore cortadas havia décadas. Brotavam delas essas novas criancinhas iluminadas, que são parte da mesma planta. Se você corta um ramo de uma planta, surge outro. Se você corta uma parte de um animal- a menos que seja um tipo especial de lagarto- ela não volta a crescer."

$\mathrm{Na}$ mitologia egípcia, o mesmo deus que rege a morte, Osíris, é o senhor da regeneração. No aspecto mitológico portanto, é preciso haver morte para que haja vida. Mas será que o que identificamos como morte existe de fato? Será que a morte não seria 
parte de um mesmo processo? Será que lutamos contra a morte ou contra a dor? Admitindo-se a morte como fim inexorável nega-se a existência do espírito e negar a existência do espírito não seria o mesmo que negar a realidade religiosa? Ao contrário, admitindo-se a morte como parte do processo da vida, inclui-se a existência do espírito e assim confirma-se a existência do mito. Como afirma Campbell ${ }^{51}$ : “Eu diria que esse é o tema básico de toda mitologia: o de que existe um plano, invisível sustentando a vida".E mais: o mito se corporifica e sua existência se torna tão contundente que não se consegue ignorálo, assim, mesmo o mais agnóstico ao procurar respostas cientificamente comprovadas, só consegue demonstrar os efeitos que o mito provoca em suas idéias. Desta forma, mesmo que todo o critério de espíritos encarnantes esteja nas mãos de um controle divino muito superior, muito mais fácil e simples é acreditar que, se a célula-tronco surge de células vivas, ela também, só pode estar viva,mas será que ela perde vida ao ser utilizada nos processos terapêuticos aos quais se destina? Pensando na célula-tronco, não posso deixar de pensar no tempo vital das demais células humanas e se nos preocupássemos muito com isto, a todo tempo estaríamos de luto pelos milhões de células de pele, pelas hemácias e por milhões de neurônios assassinados pelas bebidas alcoólicas.

$\mathrm{Na}$ década de 1970, Claude Levi- Strauss apresentou em rádio uma série de conferências que foram depois reunidas em uma pequena obra denominada: “ Mito e significado”. Nesta obra, Strauss ${ }^{52}$ diz o seguinte: “(...) histórias de caráter mitológico são, ou parecem ser arbitrárias, sem significado, absurdas, mas apesar de tudo dir-se-ía que reaparecem um pouco por toda parte. Uma criação " fantasiosa" da mente num determinado lugar seria obrigatoriamente única- não se esperaria encontrar a mesma criação num lugar completamente diferente.” (Strauss, C. 1978)

Deduz-se disto que Strauss se referia ao fato de que, apesar de se originarem de diversas civilizações, no mais das vezes um tanto distantes geográfica e temporalmente,entre si, estas civilizações parecem apresentar pontos comuns, que por falarem mais ao sentimento do que à razão, encontraram desenvolvimento no terreno das crenças e das religiões.

Assim, retornando ao Timeu de Platão, temos a criação das divindades, as mesmas que conhecemos como titãs e deuses do Olimpo e Deus(?) entrega a eles a tarefa de criação dos homens e para isso Deus teria fornecido uma receita:em primeiro lugar, os deuses encarregados do " fabrico dos seres vivos ( referindo-se ao seu aspecto anímico), deveriam 
seguir Seu modelo de criação: “ (...) aplicai-vos, conforme vossa natureza, a fabricar seres vivos. Imitai a ação do meu poder, quando de vosso nascimento...”(Platão ${ }^{53}$ ) Depois, as almas deveriam ser distribuídas entre os astros, dos quais receberiam certa influência ( isto nos faz pensar se não estariam aí as raízes da astrologia...). A natureza humana deveria ser dupla, masculina e feminina, sendo a mais viril, a masculina, depois disso as almas seriam implantadas nos corpos, por ação da necessidade : “(...) que logo as almas tivessem sido pela ação da necessidade,implantadas nos corpos..." ${ }^{" 54}$.

A partir disso Platão faz referências ao modo de proceder durante a vida; uma vida vivida com falhas acarretaria uma nova encarnação em corpo feminino,ou, até mesmo em um corpo animal: E o que tivesse bem vivido, ao tempo conveniente ir-se-ía de novo para a morada do astro pelo qual é afetado, onde teria vida feliz e semelhante a deste astro. Ao contrário, se falhasse, metamorfosear-se-ia, tomando por um segundo nascimento a natureza feminina. E, através dessas metamorfoses, se persistisse em sua malícia, segundo a maneira pela qual tivesse pecado seria sempre, à semelhança de seu vício, transformado em animal.

Deixando-se de lado as breves considerações feitas por Platão em termos de reencarnação e suas implicações cármicas, interessa-nos este diálogo pelas seguintes idéias: a criação do homem após a criação do mundo e a condição de criação da alma anterior à criação do corpo.

\section{CONCLUSÃO- PARTE I}

Dois mil e seiscentos anos depois, cientistas das mais diversas áreas continuam a pesquisar, continuam tentando responder a questão: o que é vida?Como vimos, A Física ainda não conseguiu provar sua teoria sobre o a origem do Universo.

Anaxímenes, Heráclito, Anaximandro, Tales de Mileto, Anaxágoras....nenhum deles têve que se preocupar com as questões limitantes às áreas de conhecimento que temos hoje traduzidas em exatas, humanas e biomédicas. Simplesmente indagavam a si mesmos e à natureza circundante, a resposta ficava por conta de um incrível senso de obervação e um vigoroso raciocínio ( o que não podemos negar). A ciência de ontem é a mitologia de hoje,fogo, terra,água e ar hoje, são princípios vistos de maneira esotérica, mística,mas não podemos deixar de reconhecer que sem estas primeiras idéias e a direção da 
experimentação não saberíamos o que sabemos hoje e, mesmo que saibamos muito mais do que outrora, a única certeza que temos é que este "muito mais", ainda é muito pouco.

Com exceção dos tratados de embriologia humana, as obras científicas, ou que assim pretendem ser, quando propõe-se a responder sobre o início da vida, fazem-no ou tentam fazer desde o início do cosmos. Contrariando a visão antropocentrista, ou muito pelo contrário, tentando reforçar a idéia de que precisamos saber sobre o cosmos para saber sobre homem, a pergunta "o que é vida", pelo menos nas obras consultadas neste estudo, sempre têve como proposta de resposta, o princípio da vida no Universo. Curioso pensar que esta visão digamos, holística, dos primeiros filósofos gregos ande tão em voga:nunca o homem se viu diante da urgência em reconhecer os processos vitais do planeta para salvar sua própria pele!Tanto é assim que, a cada dia vemos mais e mais surgirem programas e previsões legais de preservação ambiental, “ongs" e todo um aparato composto pela mídia das grandes massas direcionados à formação de consciências verdes!

Para a Biologia, a vida começa na célula seja ela o que for: animal,homem...o desenvolvimento se faz comandar por um certo número de proteínas produzido por um " $\mathrm{x}$ " número de genes!

Para os religiosos a vida começa por vontade e obra de uma inteligência superior e, em algumas visões, a vida material é precedida pela vida espiritual, assim, o que existe na matéria, já existia primeiro no mundo do espírito. Mas a idéia metafísica não é pressuposto apenas da religião, durante muitos séculos, a metafísica tem sido alvo de questionamentos de ordem filosófica e a partir disto gostaríamos de iniciar a discussão. Excetuando-se a noção apresentada pelo catolicismo, voz corrente contrária à utilização da célula-tronco, todas as outras religiões não vêem empecilhos nisso.

Pelo que se vê, as ciências modernas não são ainda capazes de uma resposta e isto se deve ao fato de que o objeto precisa de um novo método. Ocorre que o método atual das ciências só conseguiram chegar até o corpo,quando chegam ao que chamam de antimatéria, não sabem o que fazer.

Talvez, como disse Schrödinger haja a necessidade que se mude a maneira de investigar. Talvez o fenômeno da vida seja definido por leis ainda desconhecidas da Física padrão. Talvez precisemos voltar a maneira de pensar dos gregos e esperar que as coisas se revelem!

\section{4-O Caminho da Medicina como Técnica}


xamã da tribo, falou:- "Pensa-que -Sabe", tenho sentido fortes dores de cabeça, o senhor tem aí algum remédio? "Pensa-que-Sabe" pensou, entrou na tenda, uma hora depois voltou com uma gosma esverdeada em uma cuia e disse a "Sempre- Faminto":- Beba tudo! Sempre- Faminto obedeceu e desabou no chão se contorcendo em cólicas:"Pensa- que- Sabe" anotou em sua caderneta de couro: "enteritis oficinallis" ( nome científico da planta), causa fortes dores de barriga!Entrou na tenda, pegou o antídoto, deu a "Sempre-Faminto" e imediatamente as cólicas cessaram! Mas a dor de cabeça continuava....Novamente "Pensa-que-Sabe" entrou na tenda e voltou, desta vez, com uma gosma azul, disse:-Beba!"Sempre-Faminto" obedeceu e imediatamente ficou todo "roxo amora"! "Pensa-que-Sabe" entrou na tenda e voltou com o antídoto: imediatamente "Sempre- Faminto" voltou a cor normal! Pensa-que-Sabe anotou na caderneta: " alergicus terrificus", causa terríveis reações alérgicas! Mas as dores de cabeça continuavam ....,a cena se repetiu: o xamã entrou na tenda e voltou, uma hora depois, desta vez com um vidrinho simpático: "Sempre-Faminto" tomou, estrebuchou e caiu duro, morto! "Pensa-que-Sabe" coçou a testa... escreveu na caderneta: "venenus mortalis", extremamente mortal! Pensou: - Pelo menos já temos a oferenda para a próxima colheita...." (criação da autora)

No que diz respeito ao desenvolvimento deste trabalho importa analisarmos a questão da medicina enquanto técnica aplicada ao corpo humano. Propomos inicialmente uma visão panorâmica da história da medicina

Originalmente o termo medicina ${ }^{55}$ vem do latim, significando " ciência que tem como objetivo a conservação e o restabelecimento da saúde, que pretende curar e prevenir as doenças dos seres humanos; técnica de tratar e combater doenças."

O próprio termo "ciência" utilizado para definí-la já lhe imbui de uma condição eminentemente experimental,condição esta melhor identificada a partir do século XVII, o que não quer dizer que não tenha ocorrido desde os seus primórdios, afinal como um curandeiro de tribo teria descoberto e este ou aquele veneno se não tivesse visto alguém morrer após sua ingestão? Fora a via experimental a única via que sobraria para se adquirir tal conhecimento seria a via mediúnica em que comunicações espirituais seriam diretamente estabelecidas entre o curandeiro e os espíritos com o fim de aplicar esta ou aquela erva no tratamento desta ou daquela moléstia.

A medicina em seu início, tanto do ponto de vista clínico quanto cirúrgico, mostrou-se atrelada a ritos mágicos e idéias religiosas. Cabia ao o chefe religioso da tribo o trabalho de curar os doentes. Afirma Arturo Castiglioni ${ }^{56}$, ( historiador italiano ) que a

55 In: http:// pt.wiktionary.org/wikimedicina.Acesso em : 20/09/2008.

56 Conforme encontra-se em seu texto: "Destarte, a medicina empírica precedeu a medicina mágica e a sacerdotal, mas floresceu junto com elas, ora repousando sôbre o poder de homens investidos de dons supernaturais, ora crescendo à sombra do misticismo.”CASTIGLIONI, Arturo. História da Medicina. $1^{\mathrm{a}}$ ed. São Paulo: Editora Nacional, cap. II, p. 34, 1947 
medicina empírica tenha precedido a medicina mágica e ritualística. De fato, medicina empírica e ritos religiosos caminhavam juntos, como se tudo isto fizesse parte do tratamento que propiciaria a cura do doente.

Assim, mesmo que de maneira rudimentar, a medicina sempre foi praticada pelo homem. Observando e imitando as saídas da natureza (os animais parecem instintivamente saber que algumas plantas vulgares que crescem em nossos jardins ajudam a aliviar a dor de barriga, por exemplo), o homem também pode ter dado seus primeiros passos na ciência médica. A observação dos ciclos vitais ( nascimento- reprodução e morte) e a assistência prestada à mulher grávida estavam entre as práticas realizadas pelos curandeiros tribais, os médicos da Antiguidade. A idéia de reprodução tinha grande importância em tempos primitivos. Decorridos tantos séculos, a questão da reprodução humana ainda é alvo de grandes perguntas e questionamentos, como veremos mais adiante.

Aliada a esta prática instintiva encontramos a "medicina religiosa"que se utilizava entre outras coisas de pedras e ritos mágicos, entre outras coisas, que tinham por objetivo conferir aos seus portadores proteção e sorte. Isto se deve ao fato de que os primitivos médicos cumulavam também as funções sacerdotais: a mediunidade traduzida pelas visões e a análise de sonhos, por exemplo, contribuíam para para o tratamento já nos primórdios do que hoje em dia é tratado como medicina psicossomática.

Dentro das tradições culturais antigas, gostaríamos de ressaltar a medicina praticada pelo indígena norte-americano. Tais nações demonstraram um vasto conhecimento em relação à fitoterapia, ou seja o uso de ervas como medicamentos. Assim, das 144 drogas utilizadas pelos índios para aplicação a determinados estados patológicos, 59 tinham sido incorporadas à farmacopéia européia até a década de 1940, o que demonstra os seguintes aspectos: para ser aceita em sua eficácia, digamos, a fitoterapia indígena precisou ser testada e comprovada em meios acadêmicos, o que significa dizer: precisaram passar por processos experimentais metódicos, além disso e talvez por trás disso, alguém pode ter previsto o lucro financeiro que a patente de tais remédios poderia gerar. (Como veremos adiante, desde o advento do mercantilismo e do capitalismo, não há que se pensar em qualquer técnica experimental fomentada apenas pelo interesse pela arte ou, no caso um ardente desejo de curar).

Seguindo-se por um caminho ora místico, ora empírico, ( ora ambos) chegamos à medicina praticada na Grécia.Pode-se dizer que os primeiros raios de medicina científica, semelhante ao que ocorre na atualidade, fez-se por obra dos gregos. A partir do racionalismo grego a medicina passou a ser tratada como ciência e suas especulações 
passavam por análises dedutivas direcionadas a um fim eminentemente utilitário que visava diminuir as dores ou prolongar a vida do paciente.

Sabe-se que os primeiros filósofos eram naturalistas e biólogos que observavam e estudavam o indivíduo conjuntamente com o cosmo, estabelecendo uma linha de pensamento utilizada até hoje principalmente nas chamadas correntes da medicina alternativa que incluem a psicossomática, a medicina fitoterápica, as medicinas antroposófica e chinesa entre outras. holística. Fato é que, a medicina na Grécia contou com figuras importantes no seu desenvolvimento. Deve-se a Alcmeon de Crotona, filho da escola filosófica de Pitágoras, notáveis conhecimentos anatômicos resultantes de dissecação feitas em seres humanos e animais, e a Hipócrates, original da escola de Cós, atribui-se a paternidade da medicina. Curiosamente a medicina hipocrática tratava os doentes como, pacientes doentes ( o todo) e não como partes (órgãos) doentes, tendência que se verifica em crescimento na atualidade através das linhas já citadas. Segundo Hipócrates a doença seria um processo natural, cujos sintomas corresponderiam a uma reação natural do organismo à doença. Neste caso, o papel do médico seria o de ajudar as forças naturais do organismo a se conduzirem em direção à uma recuperação, ( parecido com o que se encontra na atual homeopatia).

No que tange a literatura médica, o Corpus Hippocraticus traz-nos valiosa contribuição no que diz respeito à cirurgia: há descrições de aparelhos cirúrgicos, técnicas de trepanação, bem como o tratamento de fraturas e luxações: A anatomia dos ossos e articulações era bem conhecida, assim como a dos órgãos genitais, além das cirurgias oftalmológicas e otorrinolaringológicas. Outra grande contribuição desta obra reside no fato dela ter lançado as raízes dos atuais códigos de ética médica.

Em comparação com a medicina grega,a medicina praticada pelos romanos parecia um retrocesso, tanto é assim que nos períodos da Monarquia e da República, a medicina romana se desenvolvia de maneira mística:só os deuses tinham o poder de curar e só a eles os homens recorriam para buscar a cura para suas doenças ${ }^{57}$. Determinadas figuras de

57 Alguém pode pensar que este comportamento seja primitivo e até mesmo por vezes "atrasado". Ainda na década de 20 conforme relatos de Pierre Verger, o curandeiro da tribo, conhecido atualmente como babalorixá ou ialorixá( quando de trata de mulher) no culto do candomblé era a autoridade procurada para resolver tanto problemas de ordem física quanto espiritual.Como estudante de medicina, durante o exercício de estágio em clínica médica, não raro deparava-me com pacientes que em suas histórias já haviam procurado o auxílio de benzedeiras e pais-de-santo. Cabe dizer que em alguns casos o problema havia sido temporariamente resolvido, há que se considerar porém que, aquilo que muitas vezes incluímos entre as idéias de superstição, não passam de conhecimento fitoterápico, como pode ser constatado na descrição do uso "terapêutico" de ervas pelas sociedades iorubás. Caso se queira verificar , veja-se: "Ewe". Curiosamente entre as diversas prescrições encontradas nesta obra, o leitor poderá se deparar com as receitas para se matar alguém e até para fazer chover. (grifo nosso) 
renome no cenário romano,por exemplo Catão( 234-149 AC), os gregos eram maus e os médicos eram os piores inimigos dos homens, além disso a medicina era tida como profissão indigna ao cidadão romano. Apesar do cenário contrário ao desenvolvimento da medicina sobressaiu-se a figura de Asclepíades de Prusa por tratar de políticos famosos como Marco Antônio, Cícero e Crasso. Asclepíades era cientista que privava suas observações do caráter metafísico. Atribui-se a ele a primeira menção à traqueotomia e a valorização singular do método de investigação científico, ( ironicamente como era feito na Grécia) .

Durante o Império, os chamados Metodistas compunham a escola de destaque em Roma. Muitos médicos desta escola eram altamente estimados pelos Césares, entre eles: Proclo, Dionísio e Antipater. Deve-se entretanto a Celso ( Aulus Cornelius Celsus), embora não se tenha certeza de que tenha sido médico ou não, os maiores escritos médicos de origem latina, principalmente traduções de escritos gregos para o latim(outra vez os gregos), o que possibilitou seu estudo durante toda a Renascença. Celso apresentou estudos pormenorizados de doenças do estômago e terapias baseadas em dietas e banhos. Uma importante contribuição de Celso utilizada ainda hoje foram os quatro sinais associados à resposta inflamatória, sendo eles:calor, rubor, tumor e dor. A partir de Celso também passou-se a ter conhecimento de técnicas cirúrgicas importantes como as retiradas de tumores e a litotripsia.

Outra figura de renome durante o Império Romano foi Galeno. Uma de suas contribuições foi a terapia de contrários, ou seja: se a doença era quente tratava-se com o frio e vice-versa, e, ao inverso de Hipócrates, sua terapia era mais localista(órgãos doentes) do que holística, ( pessoa doente).

A partir de Galeno, a medicina em Roma entrou em franca decadência. Segundo Castiglioni, as principais causas desta decadência foram as terríveis epidemias(de malária, varíola,peste,etc...) acompanhadas por cataclismas, fome e seca.

$\mathrm{O}$ avanço das idéias cristãs contribuíram para o desenvolvimento da medicina em sua forma assistencialista, a maioria das idéias, porém convergia para exercícios de fé em detrimento da investigação científica. As curas nessa época eram atribuídas aos Santos (São Roque, São Sebastião, Santo Antônio) e pouca literatura médica surgiu nesta época.

No final da Idade Média e Início da Idade Moderna observou-se o aparecimento de duas correntes científicas: a primeira originária da Escola de Salerno, obrigava o estudante de medicina a passar três anos em um curso preliminar, passando em seguida a um curso de cinco anos e mais um ano na companhia de um médico com experiência. A segunda 
corrente, denominada Escolástica, encontrava-se sob o domínio da Igreja, instituição que, na época, dominava a atividade didática e o pensamento. Neste período foram fundadas as primeiras universidades de medicina,as dissecações eram realizadas publicamente e nomes como os de Taddeo Alderotti e Guilherme de Saliceto, destacaram-se respectivamente na clínica e na cirurgia. No século XIV a Europa foi novamente assolada pela peste e pelo final do século XV, tornaram-se famosos os estudos sobre ervas,( devido ao acesso ao herbário estrangeiro conseguido através das grandes navegações) bem como se observaram tímidos relativos a anatomia e cirurgia.

A partir do século XVI, já entrando no Renascimento, a medicina refloresceu em sua forma experimental de investigação. A época se destacou: pelos trabalhos realizados em anatomia, (quanto a isto Leonardo Da Vinci foi o primeiro a apresentar um desenho preciso do útero e Giovanni Baptista Canano foi o primeiro a descrever as válvulas venosas), pelas duras críticas de Vesalio a antiga obra de Galeno,( que só havia feito observações em animais),o que irritou muito os descendentes da escolástica, e pelas contribuições de Gabriele Fallopio tais como:a descrição do aparelho auditivo, a correção apresentada para o trajeto das artérias cerebrais, a descrição do clitóris e da artéria peniana, bem como das trompas ovarianas que receberam seu nome. Considera-se porém que a maior reforma dada à medicina neste período foi aquela promovida por Paracelso.

Paracelso valorizava a experiência e a razão no estudo da medicina sem apartá-las das condições do próprio doente, o qual considerava como um microcosmo refletor do macrocosmo representado pela natureza. Paracelso afirmava que os estudos médicos deveriam ser baseados na natureza e suas leis físicas, bem como os remédios deveriam ser feitos obedecendo a princípios da química, será que não seriam estas as idéias precursoras do pensamento cartesiano?.

Com o início da Idade Moderna e sob a égide das grandes navegações, o Brasil entra para o cenário mercantil mundial e contribui para a medicina com um exótico rol de doenças tropicais desconhecias da medicina européia. Os europeus que ficavam para colonizar o país adoeciam e os remédios portugueses demoravam a chegar, quando não se estragavam durante a viagem. A saída era recorrer à flora nativa muito mais atraente e promissora no trato das doenças.

A precariedade de sobrevivência na Colônia não atraía a presença de clínicos e cirurgiões e a medicina acabava por ser exercida por parteiras, barbeiros, curandeiros, feiticeiros e charlatães que, ao contrário do que se possa pensar, através de um empirismo prático atendiam aqueles que lhes acorressem. Apesar de sua importante atividade, estes 
precários empíricos foram duramente perseguidos pela legislação portuguesa, sendo cassados constantemente pela vigilância sanitária. Em contrapartida, por apresentarem tratamento conhecido pelas famílias, muitas vezes a atividade destes curandeiros eram preferidas àquela exercida pelos médicos diplomados. Assim, a então população brasileira foi a responsável pela "cara”inicial da medicina:os conhecimentos da fitoterapia silvícola e africana se aliavam aos procedimentos grosseiros da clínica européia trazida pelos portugueses bem como às superstições e feitiçaria, muitas vezes autorizada pela própria Igreja, como por exemplo a sinistra prática de cortar a cabeça de um cão enraivecido, depois a cabeça devia ser torrada e suas cinzas serviriam para tratar alguma ferida. Além disso, os representantes da Igreja presente no Brasil queriam reavivar a Escolástica e por isso, em pleno século XVII, os primeiros brasileiros tiveram que se contentar com as práticas médicas medievais quando a Europa já se encontrava em pleno desenvolvimento das ciências naturais.

A partir do século XVII o empirismo médico tomou a direção da experimentação científica como a conhecemos. As observações e práticas médicas foram como que "contaminadas" pelo tom de liberdade fornecido pelos naturalistas da Renascença, recebendo incentivo também de áreas como a filosofia em seus aspectos experimentais o que corroborava para a refutação de dogmas e superstições. Nota-se também que, no final do século XVII e início do século XVIII história natural, fisiologia, física, química e medicina estavam interligadas. Segundo Hankins ${ }^{58}$,

(...) nesta época a classe médica dominava o estudo das coisas vivas porque eram os únicos versados em tais problemas. Todos os membros das seções de anatomia e botânica da Academia Francesa eram médicos, por exemplo: Joseph Pitton de Tournefort ( 1656-1708), Antoine de Jussieu ( 1686-1758) e Carl Linnaeus ( 1707-1778) eram médicos, assim como Bernard Jussieu, Hermann Boerhaave e Georg Stahl cujos nomes eram encontrados também em capítulos da física e da química.(...)

Pelo uso da expressão "coisas vivas", nota-se que o organismo vivo era visto como objeto, como máquina. Não é de se admirar que o mecanicismo de Descartes a idéia de uma "Filosofia Mecanicista", filosofia esta voltada para uma condição experimental de existência. Vários instrumentos relacionados à investigação científica também aplicada à medicina, surgiram nesta época, entre eles: o microscópio . A medicina tomou um aspecto internacional e cientistas da Europa inteira comunicavam-se e trocavam idéias a respeito de

58 HANKINS, T.L. Natural History . In:Science and the Enlightnment,cap.5, p.114.Texto fornecido durante o curso de Filosofia das Ciências, ministrado pelo professor Dr. Maurício de Carvalho Ramos, no

Departamento de Filosofia da USP, durante o período de Agosto à Dezembro de 2007. 
suas descobertas.

Neste século a anatomia e a fisiologia em seu aspecto mecânico de experimentação tiveram notável desenvolvimento, sobressaindo-se nomes como Giovanni Alfonso Borelli (1608-1678), Harvey, Malpighi e Valsalva, o qual analisou os tecidos musculares humanos e tentou explicar a contração muscular como um mecanismo hidráulico através do insuflamento dos tecidos musculares. Borelli também mediu a força do músculo, com especial atenção à digestão no estômago, onde acreditava residir o primeiro processo da digestão. Harvey descobriu o mecanismo de circulação sanguínea (cujas experiências escandalizaram os meios tradicionais e adeptos das idéias de Galeno ), Malpighi descobriu os capilares sanguíneos e Valsalva, além dos experimentos citados, notabilizou por seus estudos de anatomia e fisiologia da orelha. No século XVIII a experiência permitiu que se visse com maior clareza, mas ainda não sabemos o quanto deste ver (orgãos em funcionamento) era realmente ver o homem, o uso do termo mecanismo disto, mecanismo daquilo traz- nos à mente a imagem do homem- máquina e no quanto a alma havia se separado de um corpo que parecia poder subsistir como autônomo.

Uma ressalva se faz para este espírito de experimentação: preocupados com as descobertas científicas os médicos deixaram de se importar com quem mais interessava: seus próprios pacientes. Neste sentido Sydenham voltou-se aos princípios hipocráticos valorizando o doente e sua doença.( Analisando as coisas como elas se dão, vemos que a corrente do pensamento mecanicista parecia neste momento ter encontrado uma força contrária, não diferente do que ocorre hoje:( em termos científicos e de terapias médicas temos de um lado a "tecnologia de ponta" das células-tronco e de outro as linhas terapêuticas da antroposofia, da homeopatia, da medicina chinesa...polos contrários que não se eliminam, mas que se complementam.).

Muitas outras descobertas e avanços foram feitos na área médica depois do século XVII:o aparecimento das primeiras revistas científicas médicas no século XVIII,o aperfeiçoamento do microscópio, e a invenção do estetoscópio no século XIX, as descobertas de Pasteur no campo da microbiologia, da radioterapia por Curie, o uso dos anestésicos, as vacinas e agora as atuais terapias de ordem genética, demonstram o quanto a medicina caminhou, mas se este caminho se deve a alguém, este alguém é Descartes,o criador do "Método", a partir do qual as ciências modernas tomariam outro rumo, isto e a revelação feita por Darwin através da história natural revelou que "o mundo era um mecanismo gigantesco, feito de acordo com a mente de um deus onipresente e 
onipotente"(MARGULLIS e SAGAN, 2002) ${ }^{59}$

Estava "provado" o mecanicismo!

Seguindo o caminho do método, a ciência moderna chegou à célula-tronco. Neste ponto pergunta-se:Como poderia ser analisado o caminhar da medicina em relação a técnica? Como se daria a célula-tronco embrionária frente a questão da técnica?A técnica pode responder : qual o grau de humanidade da célula-tronco?

\section{1-O QUE É CÉLULA-TRONCO?}

A descoberta das células-tronco teve sua origem nas pesquisas relativas à fertilização “in-vitro”(Anexo 2) que começaram a ser feitas há aproximadamente vinte anos atrás. Em 1969, uma pesquisa extensa feita com embriões de camundongos e coelhos, envolvendo também oócitos humanos revelou que tais experimentos poderiam ser feitos em embriões humanos com o objetivo de melhorar a clínica médica. A princípio o problema para que este tipo de pesquisa se desenvolvesse residia na dificuldade em se coletar óvulos humanos, o que facilmente foi resolvido pela laparoscopia. Através deste método, os óvulos poderiam ser coletados sem que se tivesse que lançar mão de um procedimento cirúrgico invasivo e perigoso para as mulheres.

Assim, o desenvolvimento da técnica de início se deve à busca de uma saída para a infertilidade. Estudar o desenvolvimento do embrião, porém, não significava apenas resolver o problema da infertilidade, incluía também a pesquisa de anomalias cromossômicas, o diagnóstico precoce de doenças no período pré-implantatório do embrião (para constatação de doenças hereditárias, por exemplo) bem como a detecção de registros genéticos que pudessem levar ao desenvolvimento de algum tipo de câncer.

"Células-tronco. ${ }^{60}$ são as primeiras células que surgem na estruturação de
um novo organismo. Sendo primordiais, são ainda completamente
indiferenciadas, ou seja, têm plena capacidade de se diferenciarem em
qualquer outro tipo de célula. As células-tronco são de fato,
extraordinárias: são as grandes precursoras que construirão as pontes
entre o ovo fertilizado, que é a nossa origem,e a arquitetura complexa na
qual nos tornamos."( MARQUES, 2006)

As células-tronco são as responsáveis pela reposição celular dos tecidos que são danificados ao longo do envelhecimento do organismo. Grande parte dos pesquisadores acredita que estas células podem, por esta característica mudar a maneira como as doenças 
são tratadas, podendo gerar tecidos e até mesmo fazer com que cresçam órgãos.

As células-tronco se dividem em várias categorias denominadas totipotentes, pluripotentes, multipotentes, unipotentes. Para fins deste estudo interessa-nos as célulastronco totipotentes, pelo fato de serem resultantes da fusão do óvulo com o espermatozóide; são as células que derivam das primeiras divisões do óvulo fertilizado e podem originar, sem exceção qualquer tipo de célula. Nossa especial atenção se dirige a ela pelo fato de que esta caracteriza o então denominado: embrião- humano, alvo de tantas discussões .

Os pesquisadores também denominam as células-tronco conforme o local de onde podem se originar, sendo que, tais células podem provir do cordão umbilical e da placenta, logo após o nascimento; somáticas: quando provém do próprio corpo adulto ( as quais já são utilizadas em alguns tratamentos e condições especiais); embrionárias: quando extraídas de uma massa interna de células indiferenciadas que formam o embrião em estágio ainda bem precoce (quando este embrião tem entre 50 e 150 células), ou estágio de blastocisto. Grande parte dos cientistas acredita que essas células-tronco embrionárias devem possuir um potencial de diferenciação maior do que as somáticas.

Tais esclarecimentos leva-nos agora a outra questão: sobre a utilização destas células. De fato, grande parte das pesquisas científicas têm por objetivo a aplicação do estudo relacionado às células-tronco para desenvolvimento de tratamentos terapêuticos direcionados a doenças como: leucemias, linfomas, câncer de mama, esclerose múltipla, doença de Crohn, artrite reumatóide e juvenil e os mais variados tipos de doenças autoimune, distúrbios metabólicos,lesões de medula, doença de Parkinson e derrame cerebral, apenas para citar algumas de suas aplicações.

Neste sentido a Dra. Marília Bernardes Marques se indaga se a pesquisa com célula-tronco seria uma revolução na medicina? Do ponto de vista filosófico de Thomas Khun $^{61}$, não. Diferente do que ocorreu no período do Iluminismo, o que Foucault denominou "mudança de olhar", Kuhn chama de mudança de paradigma, e como ele mesmo diz, cada mudança de paradigma propõe discussões em campos esotéricos à ciência onde a descoberta se deu, daí os questionamentos filosóficos no campo da ética, da moral ,do direito, da religião.

Ocorre que as ciências modernas agem da mesma maneira há quase trezentos anos.

A técnica estabelecida por Descartes em seu "Discurso do Método" tem sido utilizada por todas as ciências modernas e esta mesma experimentação realizada pela 61 KUHN, T. A Estrutura das Revoluções Cientificas.3aed. São Paulo:Perspectiva, 1992,passim. 
medicina e áreas afins se encontram na essência da técnica.

Poder-se-ía falar em mudança de paradigma se a questão sobre a psicossomática participasse da análise das coisas, mas não é o que ocorre.

Desde a proposição da técnica cartesiana, as ciências modernas só conseguem se referir às questões relacionadas ao corpo seja ele de um homem formado ou esteja ele reduzido a uma célula, no caso deste estudo a célula-tronco embrionária, mas se temos que falar de técnica teremos que falar de corpo ( mesmo que este estudo se refira a um corpo de proporções celulares).Considerando-se o caminhar das ciências modernas, como as idéias cartesianas que contribuíram para esta técnica?

\section{5-O corpo cartesiano- objeto de pesquisa}

“NESTA DATA ( 20/05), comemorávamos o aniversário de meu pai. Cada ano que passava, mais ele se preocupava com exames médicos. E lá vinha ele, aliviado. Certo dia, porém, não. Acusava diabetes. Malgrado o cuidado, veio um derrame. Na seqüência, complicações estomacais. Cada médico que lhe atendia, passava para outro, porque os males provinham de áreas estranhas às especialidades. O resultado disso é que recebemos a notícia fatídica há uma semana da partida, em que pese ele estar lúcido, e aparentemente hígido, não fosse pequenas dores estomacais, amenizadas com remédios. O que chocou foi o tardio diagnóstico. A razão era simples: cada médico é especialista em uma área, apenas, e nenhuma especialização contempla núcleos atômicos, em que pese apregoarem o estudo das células, que são obviamente formadas por átomos. Por bizarro, o elemento primordial é estranho à cátedra! Então, só identificam o mal quando ele está instalado. É como se alguém fosse caminhar embaixo de densas nuvens; mas como não chovia, nem levou guarda-chuva. Causas não são com médicos. Eles tratam de remediar; portanto, agem depois do efeito. Atuam por realidade aparente, e não por virtualidade. considerada no positivismo e no platonismo como devaneio. Só enxergam o ser quando quebrado. Aí dizem o indefectivel "sinto muito".

As ciências médicas tem evoluído com surpreendente morosidade. Malgrado consideráveis avanços tecnológicos, capazes de instrumentar especialmente as cirurgias, o conhecimento medicinal parece, dentre todos, o mais estagnado; e, portanto, inoperante. Em pleno terceiro milênio, ainda convivemos com doenças endêmicas, para não falar das mais perversas, todas sem solução." (artigo produzido em 20/05/2008, meio eletrônico)

O “desabafo"acima tem por objetivo servir de início para a discussão dos seguintes aspectos: a situação do corpo e a situação da medicina, como técnica aplicada a este corpo. Desde Descartes o corpo foi separado da alma. Como maior adepto de seu próprio método,Descartes separou não só a alma do corpo, mas também o corpo em partes e assim separando, Descartes viu que, aos pedaços,o corpo poderia ser melhor estudado, e achou isto bom! O seu método parecia tão preciso que todas as ciências passaram a adotá-lo e 
quanto mais partes surgiam,mais objetos de estudo e mais subdivisões dentro das próprias ciências. No caso da medicina, isto é notório:da clínica geral e da cirurgia,os dois principais ramos, chegamos à hematologia, à pneumologia, à pediatria, à ginecologia, à neurologia... e nestas subdivisões o corpo foi virando um "puzzle", um daqueles quebracabeças de 5.000 pecinhas, cuja montagem depende de muita paciência e uma visão biônica para detalhes. Assim, o corpo foi separado em partes cada vez menores até chegar ao gene (e aos átomos organizados do DNA, como sugerido por Schrödinger anteriormente). Descartes, sem dúvida, foi o " divisor de águas", o arauto das ciências modernas, e mesmo que apreciemos uma visão digamos, mais holística,ironicamente, para fins de análise, dividiremos o pensamento de Descartes nas seguintes partes:Deus, corpo, alma e método. Todos os elementos da técnica cartesiana encontram-se interligados para compor um método perfeito,ou, pelo menos sem contradições que o anulem.

Para justificar a máquina-perfeita que é o corpo humano, em sua concepção, Descartes propõe, logo de início, o "Princípio da causalidade da existência de Deus"62, pelo qual o ser mais perfeito deve gerar o menos perfeito, ou seja, se há um Deus perfeito,sua criação deve ser perfeita, um gênio enganador não faria uma obra (ao menos do ponto de vista material)perfeita!Mas Descartes sabe que o homem não é perfeito, ele tem vícios,paixões, esta imperfeição de alma não viria de Deus, mas seria uma condição do próprio homem.

A concepção cartesiana sobre a criação do corpo se aproxima um pouco daquela dada pela Gênesis Bíblica, para Descartes, Deus forma o corpo como quem forma um boneco e põe nesse corpo uma espécie de "bateria" responsável por todos os seus movimentos,o que Descartes ${ }^{63}$ acredita ser o coração. Até este momento, na sua opinião o corpo ainda não tem alma, como se verifica no seguinte trecho:

“(...)contentei-me em supor que Deus tenha formado o corpo dum homem exactamente semelhante a um dos nossos, tanto na forma exterior dos seus membros, como na configuração interior dos seus órgãos, sem o compôr com uma matéria diferente da que eu descrevera, sem, de início, pôr nela nenhuma alma racional, nem qualquer outra cousa que lhe servisse de alma vegetativa ou sensitiva, limitando-se a excitar no seu coração um dêsses fogos sem luz, que eu já explicara, e que concebia de natureza idêntica à do que aquece o feno, quando se guarda sem estar

62“ (...) Deus é ou existe, sêr perfeito de que nos vem tudo que em nós existe. Donde se segue que as nossas idéias ou noções, cousas reais que provém de Deus, não podem deixar de ser verdadeiras na medida em que são claras e distintas. De maneira que as falsas que muitas vezes temos, são as que tem alguma cousa de confuso e obscuro, e participam, sob êste aspecto, do nada, isto é são assim confusas, porque nós não somos inteiramente perfeitos"In: DESCARTES,R.Discurso do Método e Tratado das Paixões da Alma.Lisboa:Coleção de Clássicos Sá da Costa,1943, 2ªed.,p.47. 63 DESCARTES.R. Opus cit. p.55,56. 
sêco, ou do que faz ferver os vinhos novos, quando se deixam a fermentar sobre o bagaço"

De fato, Descartes ${ }^{64}$ se refere ao corpo humano como máquina:"Em tudo aquilo que não diz respeito à alma,(ou seja, corpo) o homem se assemelha a uma máquina, se bem que perfeita, posto que criada por Deus. “

A partir da doutrina metafísica da absoluta separação das substâncias Descartes propõe a teoria do homem-máquina e do animal-máquina. Segundo esta teoria todas as funções orgânicas poderiam ser comparadas, segundo Descartes, ao funcionamento de uma máquina muito bem construída. Os seres que não possuem alma, os animais seriam constituídos apenas por esse maquinismo.

Mas, como seria formado este corpo?De acordo com Descartes ${ }^{65}$, o corpo seria toda máquina composta de ossos e carne:

"Entendo por corpo tudo o que pode ser limitado por alguma figura, que pode ser compreendido em qualquer lugar e preencher um espaço de tal sorte que todo outro corpo seja excluído; que pode ser sentido ou pelo tato, ou pela visão, ou pela audição ou pelo olfato; que pode ser movido de muitas maneiras, não por si mesmo, mas por algo de alheio pelo qual seja tocado e do qual receba a impressão."

Já neste trecho, Descartes coloca as primeiras condições que viriam a definir o método: o corpo é material, deve ser visto, deve ser palpável. O corpo cartesiano é literalmente "enquadrado" dentro da matemática, ele apresenta uma condição de calculabilidade. Este corpo Descartes chamou "substância extensa", ao contrário da alma que além de ser substância separada do corpo só pode ser percebida pelo pensamento. $\mathrm{O}$ mais interessante é perceber como Descartes ${ }^{66}$ chegou à idéia de separação entre corpo e alma, como podemos ver no seguinte trecho:

"Com efeito, examinando as funções que, em virtude disso, um tal corpo deveria ter, encontrava exactamente aquelas que em nós podem existir sem que o pensemos e sem que, por consequência, a nossa alma, isto é,essa parte distinta do corpo, cuja natureza, como já dissemos, consiste apenas em pensar, para tal contribua, funções que são as mesmas em todos, o que permite dizer que os animais sem razão se nos assemelham..."

Perceber o funcionamento do sistema nervoso autônomo serviu para que Descartes pensasse no corpo como uma máquina o que, no século XVII até poderia se esperar:o coração, a "máquina vital" por excelência,os rins, o fígado, os pulmões fazem o seu trabalho independente da nossa vontade, independente do nosso pensar.

64 SILVA, F.L. A metafísica da Modernidade. São Paulo: Ed. Moderna, 1 a ed,p.95

65 DESCARTES R. Meditações Metafísicas. São Paulo: Nova Cultural, 1991,p.175.

66 DESCARTES.R.Discurso do Método e Tratado das Paixões da Alma, 1943,p.55,56. 
O pensar, intuiu Descartes ${ }^{67}$, é o que nos dá a noção de que temos alma. Alma esta que é colocada por Deus, ( ser perfeito) em nós:

“ De maneira que restava apenas admitir que tivesse sido posta(alma) em mim,por um ser cuja natureza fôsse verdadeiramente mais perfeita do que a minha, e que mesmo tivesse em si todas as perfeições que eu poderia idealizar, isto é, que fôsse Deus, para tudo dizer numa palavra"

Admite Descartes que, todas estas coisas são feitas e sentidas pela presença do corpo, mas pensar é algo que vai além do corpo, acabando por determinar o próprio sentido de existência à característica de pensar. Em suma, para Descartes,então, o corpo, criação de Deus, seria uma massa composta de osso e carne, como um boneco mecanicamente articulado, cuja essência, como definiria mais adiante em outro trecho deste mesmo texto,se define pelo pensar como se demonstra ${ }^{68}$ :

"E, embora talvez ( ou,antes, certamente, como direi logo mais) eu tenha um corpo ao qual estou muito estreitamente conjugado, todavia, já que, de um lado tenho uma idéia clara e distinta de mim mesmo, na medida que sou apenas uma coisa pensante e inextensa, e que de outro, tenho uma idéia distinta do corpo,na medida em que é apenas uma coisa extensa e que não pensa,é certo que este eu, isto é, minha alma, pela qual eu sou o que sou e verdadeiramente distinta de meu corpo, e que ela pode ser ou existir sem ele."

Descartes $^{69}$ acreditava ter provado que a alma racional não poderia ser derivada do poder da matéria, mas sim que ela deveria ter sido criada:

“ (...) eu descrevera a alma racional e mostrara que ela não pode ser, de modo algum, derivada do poder da matéria como as outras cousas de que falara, mas que deve expressamente, ter sido criada;mostrara mais: que não basta que esteja alojada no corpo humano, como um piloto no seu navio, talvez para mover os seus membros, mas que é preciso, para ter, além disso, sentimentos e apetites semelhantes aos nossos e dessa maneira formar um verdadeiro homem, que esteja junta e mais estreitamente unida a ele"

Estavam assim separados, Deus e homem, corpo e alma. Mas embora a alma estivesse separada do corpo ela mantinha com este uma ligação, que segundo Descartes se dava pela glândula pineal ${ }^{70}$, como se dispõe em Paixões da Alma ${ }^{71}$ :

“Art. 31. que há uma pequena glândula no cérebro, na qual a

67 DESCARTES, R.Opus cit., p.42.

68 DESCARTES,R.Opus cit, p.217.

69 DESCARTES, R.Opus cit,p.70

70 Sobre a pineal: ver trabalhos em psicobiofísica do Dr Sérgio Felipe de Oliveira. In: ippb.org.br(grifo nosso)

71 DESCARTES.R. Os Pensadores. São Paulo: Nova Cultural,1991,p.88. 
alma exerce suas funções, mais particularmente do que nas outras partes. É necessário também saber que, embora a alma esteja unida a todo o corpo, não obstante há nele alguma parte em que ela exerce suas funções mais particularmente do que em todas as outras; e crê-se (...) que a parte do corpo em que a alma exerce imediatamente suas funções, não é de modo algum o coração, nem o cérebro todo, mas somente a mais interior de suas partes, que é certa glândula muito pequena, situada no meio de sua substância ."

Descartes denominou a glândula pineal de "sede da alma"72: " Mas é através da glândula pineal que a alma age sobre o corpo, e é também através dela que recebe as excitações provenientes da sensibilidade."

Para Silva, a união entre a alma e o corpo é incompreensível por envolver a comunicação de duas substâncias metafisicamente incomunicáveis:

\footnotetext{
“ Ora se no domínio da físico-matemática posso de alguma maneira separar essência de existência e obter conhecimentos claros e distintos da parte essencial do mundo físico, no caso do homem enquanto união substancial não posso operar da mesma forma essa separação sem perder o objeto. É bem verdade que o pensamento, enquanto essência do Eu, é separável e pode ser conhecido autonomamente. Mas a característica do misto no composto substancial é a indissociabilidade de fato das substâncias. Descartes ilustra este fato dizendo que a alma não está no corpo como o piloto em seu navio, isto é, apenas como espectador do que acontece na parte material. A alma está substancialmente ligada ao corpo e com ele mantém relações de total intimidade. Se desejo conhecer este misto e como ele age, será precisamente enquanto misto que terei de conhecê-lo."
}

Descartes também fez uma distinção entre as almas dos animais e as almas dos homens, no que diz tange à morte. Acreditava Descartes que as almas dos animais deveriam ser diferentes das dos homens porque se fossem semelhantes teriam o mesmo destino após a morte. Para Descartes, se as moscas e as formigas morressem (corpo) morria também sua alma. Ao contrário, no homem, a alma é de natureza diferente, não está sujeita a morrer com seu corpo ${ }^{73}$ “(...) ao passo que, sabendo quanto elas diferem, compreendem-se as razões que provam que a nossa é inteiramente independente do corpo e que,por conseguinte, não está sujeita a morrer com êle."

Estavam assim dispostos os principais elementos formadores da teoria mecanicista: um corpo mecânico, separado da alma e que indicaria o modo como as ciências modernas viriam a se desenvolver, tratando o corpo como algo isolado até de si mesmo!

Renauld Barbaras ${ }^{74}$ entende que a teoria mecanicista proposta por Descartes relaciona-se apenas ao aspecto da extensão: assim, o corpo estaria condicionado a leis

72 SILVA, F.L.A metafísica da Modernidade.São Paulo: Ed.Moderna,p.92

73 DESCARTES, R. Discurso do Método e Paixões da Alma.Lisboa:Coleção Clássicos Sá da Costa, $2^{\mathrm{a}}$ ed., 1943, p.71.

74 Renauld Bárbaras é professor titular de História da Filosofia da Universidade Blaise- Pascal de ClermontFarrand. 
físicas, a alma, por sua vez seria experimentada na consciência, independente das leis da matéria. De acordo com o pensamento cartesiano, os animais seriam máquinas por não terem alma ( neste caso a alma estaria relacionada à faculdade de pensar, coisa que os animais,cartesiana, pareciam não fazer), mas os homens seriam a união de um “ corpomáquina" com uma alma inteiramente espiritual. Segundo Barbaras, o desenvolvimento das investigações científicas sobre o cérebro ${ }^{75}$ no século XX, constituiu um reforço para a filosofia materialista. Porém mesmo tais descobertas parecem não localizar, neste corpo material, a consciência, esta, parece desconhecer os processos cerebrais. Teorias deterministas, como o princípio da causalidade só têm sentido portanto quando associadas à matéria, mas embora a consciência não esteja presente na matéria ela depende dos processos fisiológicos do corpo para se manifestar e para se fazer perceber. Em tempos informatizados como os que vivemos, e com a devida licença, gostaríamos de ilustrar a questão com o seguinte exemplo:pela visão cartesiana,o cérebro seria como o CPU, ou melhor o processador, o computador, para que ele interaja conosco, necessita de um softer, uma essência, um programa, que existe independente do processador. A experiência psíquica portanto, seria irredutível aos movimentos mecânicos do cérebro. A alma parece depender do cérebro para se expressar .

Segundo Barbaras ${ }^{76}$ : De fato a alma depende do cérebro, o que significa que cada uma das duas realidades em relação é constituída de uma maneira tal que pode, de fato, se articular com a outra e constituir com ela uma só realidade que se chama realidade humana.(BARBARAS, R. 2003).

Segundo os discípulos de Descartes, através do "Sistema das Causas Ocasionais", Deus faria nascer os pensamentos na alma, através do movimento da matéria, ao passo que Deus, através da alma, forneceria movimento ao corpo.

Mas se a alma depende do cérebro para se expressar, como poderemos perceber a expressão da alma do embrião? Isto significaria perguntar : o embrião tem alma?Pelo que foi visto na parte I, não, e se fôssemos pensar na questão através da perspectiva cartesiana, também não, afinal segundo Descartes, Deus faz o corpo e o coração e depois disso é que ele determina a alma para animá-lo, além disso, como a alma se ligaria a um embrião sem pineal ?

75 Descobriu-se, que cada estímulo gerado exteriormente ao corpo, ou mesmo cada emoção tem sua sede em um determinado local do cérebro sendo possível o seu controle através de medicamentos que atuem juntos aos neurotransmissores. Sabe-se por exemplo que uma baixa quantidade de serotonina no cérebro pode indicar depressão.

76 BARBARAS, Renaud. A Alma e o Cérebro. In: O Homem - Máquina A Ciência Manipula o Corpo.São Paulo: Companhia das Letras. 2003, p.72. 
Segundo Renauld Barbaras ${ }^{77}$ :

O projeto ( cartesiano) de dar conta da existência humana a partir de um modelo mecânico justifica-se pelo fato de que temos um corpo que, como a palavra o indica, é uma coisa corpórea submetida às leis da mecânica como qualquer outro corpo: se for empurrado, vai para frente, se for puxado recua, se for levantado e largado, cai no chão.

(BARBARAS, R. 2003)

O pensamento cartesiano estaria certo se Freud não tivesse estudado o psiquismo e a depressão, o transtorno bipolar, entre outras doenças do psiquismo não fossem tão conhecidas! $\mathrm{Na}$ década de 90 , as doenças mentais eram tratadas em termos de "distúrbios químicos", o que significa dizer alterações nos níveis de neurotransmissores, principalmente, no caso da depressão, a serotonina. Tendo ouvido isto de um professor de psiquiatria, ( na época era estudante de medicina) me perguntava, sobre o início da doença: Por que,o tal mecanismo produtor de tal neurotransmissor havia começado a falhar?O mais curioso era que, na cidade de São José do Rio Preto, o hospital psiquiátrico público funcionava junto a um centro espírita, aliás, o próprio hospital chamava-se "Bezerra de Menezes".Conforme informações do próprio professor de psiquiatria, alguns pacientes às vezes chegavam em condições que eram posteriormente diagnosticadas como esquizofrenia ou psicose maníaco depressiva e ao passarem por um certo número de tratamentos espirituais, saíam do estado de surto e melhoravam sem o auxílio de remédios...Assim,mesmo que os distúrbios de ordem psíquica tenham se deparado com abordagens não tão técnicas a princípio, o método cartesiano como um contágio, quase uma força inconsciente, é o que define o caminho das ciências modernas, desta forma tudo o que não se encontra dentro deste "padrão científico", parece indigno de confiança.

Para Barbaras, a alma ultrapassa o corpo em todas as suas dimensões: o corpo existiria apenas no presente, a alma pode "viajar no tempo". É pela memória, considerada atributo da alma que temos acesso ao passado e podemos deixar, por alguns momentos a dimensão do presente. Neste aspecto, Barbaras indaga sobre a irredutibilidade do homem à condição de máquina pelo simples fato de ter alma. Barbaras ${ }^{78}$ propõe, assim, a noção de consciência: a existência humana se dá pela experiência do ser e de uma consciência capaz de perceber esta existência, como propõe: (... ) a consciência ...é a identidade absoluta do ser e do aparecer, de modo que sua experiência - o fato de estar consciente - é a garantia de sua existência(BARBARAS, R.2003).

Mesmo sendo a consciência um atributo do ser,a proposta de Barbaras se torna tão 
vaga quanto a intuição e o pensamento. O método cartesiano só pode ser aplicado ao corpo, e, por tudo que já foi dito,não serve para se descobrir o "mecanismo" da alma .

\section{6 -A terapia de célula-tronco - A questão da Técnica}

"Kartésia vinha assim: velha,cansada, tropeçando nos próprios sapatos...Apesar da idade e dos óculos enormes, Kartésia continuava impecável no seu trajar: sapatos de bico quadrado, de verniz preto, engraxados como espelho;saias abaixo dos joelhos( de acordo com os preceitos de moda sugeridos à uma senhora de idade); camisa de babados "fru-fru" abotoados até o pescoço; colar de pérolas, maquiagem e penteado irrepreensiveis! Kartésia era assim, atenta aos detalhes (da sua vida e dos outros) e muito,muito racional...Com o passar dos anos as articulações enrijeceram e ela vivia tropeçando, caindo até às vezes. Os remédios alopáticos não faziam efeito,o médico não sabia o que fazer com ela e ela não procurava novas saídas: lhe indicavam isto, aquilo, que nada: Kartésia não perdia a rigidez! Todas as suas ações eram calculadas com precisão: até o cabelo era cortado com o auxílio de uma régua!

Foi então que um dia, andando na rua, Kartésia encontrou Fenomena: Fenomena era bem mais velha, como ela mesmo gostava de dizer: - "Tão velha como a Grécia Antiga!

Fenomena era uma dessas senhoras "sacudidas", como se diria em expressão popular:praticava yôga, pilates, meditação... Quando encontrou Kartésia, esta se queixou:- Ah, não vou bem! Estou com artrite, vivo tropeçando, tenho dores na coluna...

Fenomena lhe sugeriu uma mudança de perspectiva, disse: - Kartésia, você parece que usa a mesma roupa há trezentos anos! Você deve ser mais flexivel, viver um pouco mais! Kartésia prometeu pensar... pensando ela existia.." ( criação da autora)

Analisando-se a célula-tronco em relação ao seu contexto,no que tange às questões de ordem genética e da terapêutica médica, percebemos que, desde o início, tanto célulatronco quanto técnica são coisas intrínsecamente ligadas. Neste aspecto a melhor leitura que encontramos,pelo menos a que pensamos ser mais adequada à questão da técnica foi aquela feita por Heidegger em sua "A Questão da Técnica": nada retrata melhor a situação de conflito originada quando a proposta de utilização das células-tronco embrionárias para pesquisa foi lançada no mundo.

Não foi sem razão, então, que nos referimos anteriormente à visão cartesiana sobre corpo e alma.

Heidegger ${ }^{79}$ compreende que a questão do "corpo" é uma questão da técnica. Para Heidegger, corpo e técnica são entes conectados: “(...) o problema do método da ciência é 
idêntico ao problema do corpo. O problema do corpo é em primeiro lugar um problema de método." 80

Na obra, “ Os seminários de Zollikon”,Heidegger questiona o significado da técnica na ciência moderna. De fato ele questiona o método em si, o modo de se fazer ciência.

Desde Descartes as ciências modernas se baseiam nos padrões da mensurabilidade da maneira como foi proposta em seu método. Para Descartes, a ciência se vincula ao domínio prático no mundo da vida, segundo Franklin Leopoldo Silva ${ }^{81}$ : "Vê-se,... que, em Descartes, ciência e técnica estão estreitamente ligadas. Essa vinculação é uma característica marcante da civilização moderna em que a ciência se prolonga naturalmente nas suas aplicações técnicas"(Silva,F.L.A metafísica da Modernidade,p.94)

Segundo Heidegger, a ciência moderna se baseia na "mensurabilidade" como método de diferenciação entre o somático (mensurável) e o psíquico ( não mensurável), ou como diria Descartes: substância extensa, ( corpo) e substância pensante, (alma).

Este é o dogma estabelecido pelo pensamento científico natural:toda a natureza é determinada pela mensurabilidade. Acontece que o medir é "co-determinado pelo corporar" 82 então a mensurabilidade não pode ser medida.

Para Heidegger ${ }^{83}$, a coisa só pode ser medida quando for pensada como objeto:“ $\mathrm{O}$ medir só é possível quando a coisa (Ding) é pensada como objeto, representada em sua objetividade ( Gegenständlichkeit). Medir é uma maneira pela qual eu posso deixar uma coisa por si mesma me confrontar".

Mensurar é calcular e este calcular é pré-estabelecido em "medidas padrão", o que inclui uma suposição: a de que se pode dominar os processos naturais, estabelecendo-se uma espécie de posse, ou como diria Descartes: "Tornamo-nos mestres e donos da natureza" (Discurso do Método).

No que diz respeito à técnica médica a afirmação de Heidegger sobre a mensurabilidade poderia ser exemplificada com o que vemos, por exemplo, nos exames laboratoriais:um simples hemograma demonstra "padrões" distribuídos entre faixas de normalidade, valores acima ou abaixo podem significar doença. Mas perguntamos: será

80No seguinte trecho, Heidegger deixa clara a relação entre o método cartesiano e a sua maneira de ver as coisas: “(....) a corporeidade do homem está ao lado da objetividade do conhecimento da Física. Isto é somente característico da pesquisa científica ou é característico dela porque o corporar do corpo em geral codetermina todo ser-no-mundo do homem? Se for assim então o fenômeno do corpo só pode ser enfocado se, na superação crítica da relação sujeito-objeto válida até agora, o ser-no-mundo for propriamente experienciado, propriamente suportado como traço fundamental do Dasein humano.Trata-se de ver que a ciência como tal, que o conhecimento teórico- científico como tal, é um modo fundamentado do ser-nomundo, fundamentado no ter corporal de mundo".Opus cit.,p.120-121.

81 SILVA, F.L.A. A metafísica da modernidade.São Paulo: Ed. Moderna,p.94.

82 Heidegger, M. Opus cit, p.134

83 Ibidem,p. 125 
que o padrão de normalidade de um organismo é igual ao de outro: e se o meu organismo funciona bem com "n" números de eritrócitos, mesmo que este " $n$ " esteja abaixo ou acima dos ditos padrões?Como encaixar a capacidade de mudança do gene dentro desses padrões?Como diria Heidegger ${ }^{84}$ :“O medir como comparação visa uma equação. Tal comparação é um calcular.” Daí a dificuldade em se medir o psíquico: “(...) o psíquico pode ser sentido intuitivamente, mas sentir e intuição são coisas igualmente indeterminadas." ${ }^{\text {85 }}$

Como foi dito o corpo pode ser medido, então ele se torna objeto e é como fenômeno constituído no lugar da objetividade que as ciências naturais vêem o ser das coisas, ou seja, o modo como algo se torna presente para o homem, assim, na ciência moderna um ente só é compreensível se couber dentro de uma medida representada por mim. Segundo Heidegger, até a Idade Média não havia representação das coisas. As coisas se davam como se davam. A partir da Idade Moderna as coisas passaram a ser representadas e a medida dessa representação desde então têm sido o próprio homem. Esta mudança de paradigma que se verifica entre a Idade Média e Moderna se deu por causa do Método Cartesiano especialmente, ( não que a própria técnica já não estivesse presente desde o experimentar,como veremos adiante), como se dispõe $e^{86}$ :

"A presença não é mais tomada como o que é dado a partir de si mesma, mas como aquilo que se contrapõe a mim como sujeito pensante, como é ob-jezado para dentro de mim. Esta forma de experiência do ente só existe a partir de Descartes, isto é, desde que o homem alçou a condição de sujeito"

Na ciência moderna os entes passam a ser representados pelo homem, o que se constitui em uma limitação,é uma adaequatio intellectus ad rem: "um se medir constante do homem com a coisa" ${ }^{97}$. É justamente isto que encontramos neste estudo quando falamos sobre o início da vida: a medida da vida para a Física seria o que se mede pela representação dada pelo homem aos átomos, a medida da vida na biologia seria o que se pode mensurar pela representação dada pelo homem à célula e quando o homem se vê representado nesta célula dá-se a confusão encontrada na religião: o homem se vê representado no embrião congelado, porque como não pode "medir" o psíquico ( nem sequer faz idéia de como isto poderia ser feito), até a alma aparece "ob-jezada", mas intuise que a materialidade não seja condição da alma e assim o próprio homem se relega totalmente à condição de corpo material, e, neste ponto, considerando-se o homem ser

84 Heidegger, M. Opus cit.130

85 Ibidem, p. 128.

86 Ibidem, p. 126.

87 Ibidem, p.127 
somático e psicossomático, se perguntarmos novamente, mas talvez de forma um poco diferente:a célula-tronco embrionária tem alma? A célula-tronco embrionária é ser humano? Só nos resta ou o caminho da lógica estabelecida por nossas próprias representações ( caminho este que foi esmagado pelo pensamento católico) ou aceitarmos as respostas dos espíritos.

A impressão que se tem é a de que as ciências modernas avançam em suas investigações e cada vez mais parecem conhecer o corpo humano, conseguem até certo ponto melhorar a qualidade de vida, e, neste aspecto as terapias de célula-tronco (independente serem elas embrionárias ou não) prometem tratar da doença em sua origem, corrigindo o "defeito" genético, mas e se a origem dos distúrbios, das doenças não se iniciarem nos genes? E se a causa estiver um "pouco mais pra lá" do corpo físico?A terapia irá corrigir o gene, daquela doença naquele embrião pré-implantatório,mas será que uma doença não poderá se manifestar de uma outra maneira, levando-se em conta também o fato de que o homem não vive numa bolha, e que os processos de mutação e seleção natural, de acordo com Darwin se deram pelas interações do organismo com o meio, então que "garantia de cura" seria esta? A própria célula implantada entra em contato com as demais células do organismo, interage com o corpo, então onde a garantia? Quanta pretensão...Sobre isto diz Heidegger ${ }^{88}$ :

“Mas todas as nossas discussões não podem ser tomadas como científicas. A ciência como tal não é rejeitada, de nenhuma maneira. Só a sua pretensão ao absoluto, a ser o parâmetro de todas as verdades, é julgada pretensiosa." Heidegger ${ }^{89}$ considera esta pretensão inaceitável,pareceme necessário, como método totalmente diferente, "envolver-se especialmente em nossa relação com o encontro"

Todo método é como uma receita, se observarmos a técnica de fertilização "in vitro"(anexo2), veremos que ali está descrita a "receita" para se fazer um embrião.

Segundo Heidegger, método em grego, significa "caminho", caminho que leva a algo", "caminho pelo qual um assunto é estudado. O caminho é algo que se desvela por si: não dá para se estabelecer o caminho de antemão ( o que Thomas Edson sabe muito bem depois de 999 tentativas de inventar a lâmpada), como diz Heidegger ${ }^{90}$ : “ Não se pode estabelecer de antemão, sem mais nem menos, de que maneira o assunto determina a espécie de caminho que a ele conduz, de que maneira a espécie do caminho permite alcançá-lo".

A visão de Heidegger sobre o método é liberta de padrões e medidas,o que exige

88 Ibidem. p, 136

89 Ibidem,p.137

90 Ibidem,p.128 
uma desconstrução das nossas noções e representações, daí a dificuldade. Lembra-nos um pouco a maneira como as crianças vêem as coisas pela primeira vez e depois as descrevem de uma maneira totalmente diferente do esperado por um adulto!Neste sentido se colocássemos um embrião em um microscópio, o cientista descreveria o embrião como um amontoado de células neste ou naquele estágio, ( mórula, blástula, gástrula etc...), um padre olhando o mesmo embrião veria o "ser humano no início da vida" e a criança veria uma porção de bolinhas juntas!

Ao contrário de Heidegger, o método,o "caminho para” já está todo previsto, o objeto ou a "res-objecto" já está posta de antemão e de acordo com o que se anuncia em suas regras:

" O primeiro consistia em nunca aceitar como verdadeira qualquer cousa, sem a conhecer evidentemente como tal; isto é, evitar cuidadosamente a precipitação e a prevenção;não incluir nos meus juízos nada que se não apresentasse tão clara e tão distintamente ao meu espírito, que não tivesse nenhuma ocasião para o pôr em dúvida."

"O segundo, dividir cada uma das dificuldades que tivesse de abordar no maior número possível de parcelas que fossem necessárias para melhor as resolver"

" O terceiro, conduzi por ordem os meus pensamentos, começando pelos objectos mais simples e mais fáceis de conhecer, para subir pouco a pouco, gradualmente, até ao conhecimento dos mais compostos."

“ E o último, fazer sempre enumerações tão completas e revisões tão gerais, que tivesse a certeza de nada omitir" ( Descartes ${ }^{91}$ )

Então se o "caminho para" em Heidegger é liberto, o método cartesiano "engessa" as coisas dentro de parâmetros que podem ser ou não verdade. As coisas já estão postas dentro de proposições matemáticas e, se não couberem dentro dessas proposições não podem ser verdadeiras.

Heidegger $^{92}$ compreende o método cartesiano da seguinte forma:

“ O que então significa método? Método significa o caminho no qual o caráter do campo a ser conhecido é aberto e limitado. Isto significa: a natureza é colocada de antemão como objeto e somente como objeto de uma previsibilidade universal. A veritas rerum, a verdade das coisas, é veritas objectorum, verdade no sentido da objetividade dos objetos, não a verdade como coisidade das coisas presentes por si. Verdade não significa aqui,pois manifestação ( Offenbarkeit) do diretamente presente; a verdade é definida como aquilo que pode ser verificado de modo claro,óbvio, seguro e indubitável, isto é, certo para o eu que representa. O critério desta verdade como certeza é aquela evidência que alcançamos

91 Descartes, R. Discurso do Método e Tratado das Paixões da Alma. Lisboa:Coleção de Clássicos Sá da Costa, $2^{\mathrm{a}} \mathrm{ed}, 1943, \mathrm{p} .22-23$.

92 Heidegger, M. Opus cit.p. 132 
quando,após eliminar tudo o que for de alguma forma duvidoso, chegamos ao indubitável que deve ser reconhecido como fundamentum absolutum et inconcussum, fundamento absoluto inabalável."

Heidegger vê nisso uma forma de ataque monstruoso do homem à natureza, calcado na idéia que tem o homem de ser senhor e possuidor da natureza. Assim conduzindo as coisas, o homem rebaixa a mente a condição de "operadora da calculabilidade" 93 : “(...) só deixa valer seus pensamento como um manipular de conceitos operativos e representações de modelos e modelos de representações- não só deixa valer, mas ousa apresentar a consciência reinante nesta ciência até mesmo como consciência crítica numa cegueira monstruosa.

Ainda:

“Em princípio o matemático é igualmente evidente e certo. Aí está a razão porque a colocação da natureza como objetividade calculável conhece ao mesmo tempo a calculabilidade como uma definição matemática. Mas neste método, isto é, neste tipo de colocação antecipada da natureza como âmbito de objetos calculáveis já está uma decisão de consequências quase imprevisíveis, a saber: tudo o que não apresenta o caráter dos objetos possíveis de determinação matemática é eliminado como sendo incerto, isto é, inverídico, não verdadeiro." ${ }^{94}$

As evidências do quão equivocada é esta maneira de pensar se refletem nas próprias dificuldades que o homem encontra na área de meio-ambiente atualmente. No que tange ao meio-ambiente há a informação de que uma área desmatada demoraria vinte e cinco anos para repor suas espécies naturalmente. Vê-se aí a limitante noção cartesiana de tempo, não se leva em consideração o clima do planeta como um todo,os desastres naturais,etc...

A questão da técnica em Heidegger ${ }^{95}$ tem por objetivo questionar a própria essência da técnica. Como se a técnica fizesse um "exame de consciência sobre si mesma." Para tanto Heidegger ${ }^{96}$ explora a concepção da técnica quanto ao agenciamento de meios para a consecução de fins,o que ele faz através do sentido grego da teoria causal proposta por Aristóteles. Segundo esta teoria ${ }^{97}$ as quatro causas teriam um comprometimento com a

93 HEIDEGGER,M. Opus cit., p.133.

94 Ibidem.

95 "Mas de modo mais triste estamos entregues à técnica quando a consideramos como algo neutro; pois essa representação, à qual hoje em dia especialmente se adora prestar homenagem, nos torna completamente cegos perante a essência da técnica."HEIDEGGER,M.A Questão da Técnica.In:Scientiae Studia- Revista Latino -Americana de Filosofia e História da Ciência. São Paulo,.5,nº3,p.376.

96 "Um diz: técnica é um meio para fins. O outro diz: técnica é um fazer do homem. As duas determinações da técnica estão correlacionadas. Pois estabelecer fins e para isso arranjar e empregar os meios constitui um fazer humano. O aprontamento e o emprego de instrumentos, aparelhos e máquinas,o que é propriamente aprontado e empregado por elas e as necessidades e os fins a que servem, tudo isso pertence ao ser da técnica. O todo destas instalações é a técnica. Ela mesma é uma instalação;expressa em latim, um instrumentum. HHEIDEGGER,M. Ibidem.

97 "Há séculos a filosofia ensina que há quatro causas: 1. a causa materialis,o material, a matéria a partir da qual, por exemplo, uma taça de prata é feita; 2. a causa formalis, a forma, a figura, na qual se instala o material;3.a causa finalis,o fim,por exemplo,o sacrifício para o qual a taça requerida é determinada segundo matéria e forma;4. A causa efficiens, o forjador da prata que efetua o efeito, a taça real 
produção da coisa, neste sentido: "a causa material seria aquela em que há uma espécie de compromisso entre a matéria e a produção do objeto, a causa final se refere ao compromisso entre a

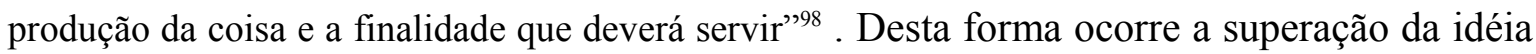
de se fazer algo, a partir de alguma coisa, para certo fim. Em Heidegger"9 : “As quatro causas são modos de comprometimento "Verschulden" relacionados entre si"

Heidegger, neste apecto, faz uma distinção entre a poiesis "natural”, a produção que se orienta por processos naturais, a techné, a produção do artesão, ainda atrelada ao natural e a episteme que significa o conhecimento da produção, que pode se afastar do sentido da produção em direção a outros níveis de compreensão. Ocorrem desta forma três formas de desocultamento ( alethéia).

Associando-se esta idéia a questão da célula-tronco embrionária teríamos que: o processo de fecundação da maneira tradicional seria "poiesis", a fecundação "in-vitro" seria “techné”, enquanto que a própria técnica da reprodução assistida seria episteme. A poiesis e a techné requerem da natureza ( espermatozóide, óvulo), na poiesis há uma continuidade entre a produção natural e a interferência humana, já na techné, óvulos e espermtozóides seriam coletados para gerar um certo número de embriões, nesse caso não há um aproveitamento natural, mas sim algo que é aproveitado para (ser consumido).Têm-se assim um " desabrigar a partir do critério de utilização". ${ }^{100}$

Para Heidegger o caráter instrumental existe mas antes que ele se torne instrumental o ente habita o mundo: inverte-se a ordem das coisas: "não é a usina que está no rio", mas o rio que está na usina." ${ }^{101}$ Do ponto de vista da célula-tronco embrionária isto poderia ocorrer se os embriões fossem criados exclusivamente para fins de pesquisa, não foi o que aconteceu ( pelo menos não até onde sabemos). Penso mais que há neste caso ou um desconhecimento ou um não pensar ou uma inconsequência, ou nos termos de Heidegger um descomprometimento:- se antes havia uma "causa material" para a criação dos embriões esta se dava em comprometimento com o desejo de ter filhos através da fecundação artificial; uma inconseqûencia ou um não pensar sobre, ou mesmo, porque não

acabada.Ibidem,p.377.

98 SILVA, Franklin L.Opus cit.,p.369.

99 HEIDEGGER,M. Opus cit., p.378.

100 “O desabrigar imperante na técnica moderna é um desafiar "Herausfordern" que estabelece,para a natureza, a exigência de fornecer energia suscetível de ser extraída e armazenada enquanto tal."

HEIDEGGER,M. Ibidem, p.381.

101“ No âmbito dessas consequências engrenadas de encomenda elétrica aparece também o rio Reno como algo encomendado. A central hidroelétrica não está construída no rio Reno como a antiga ponte de madeira, que há séculos une uma margem à outra. Pelo contrário, é o rio que está construído na central elétrica. Ele é o que ele agora é como rio; a saber, a partir da essência da central elétrica,o rio que tem a pressão da água.’(HEIDEGGER M. Opus cit., p.382). 
dizer "um desconhecimento" levou à condição dos embriões sobrantes:e aí, o que fazer?

Pensamos que, neste caso o método cartesiano, se é que houve, não funcionou. Também falhou uma observação crítica da técnica enquanto técnica, mas não podemos nos esquecer da condição mercantil: na década de 90, a reprodução assistida fez a fama de muitos ginecologistas.

Este é o problema: a técnica sem crítica!Neste aspecto não houve nada a não ser uma experimentação deslumbrada e mal ajambrada! Ou, como diria Heidegger: descomprometida mesmo!Por isso, a cada dia que passa, a mídia e a própria técnica parecem mais admiradas de seus feitos, sem se darem conta de sua própria essência! ( ver anexo4)

Segundo Heidegger, nem sempre a cronologia histórica coincide com a verdade em seu caráter essencial: a técnica moderna é uma manifestação posterior à ciência experimental, a essência,porém ( natureza como complexo de forças a ser calculado) já estava presente desde o início. Essa maneira como a técnica moderna se desoculta, Heidegger chamou: "armação"102.

Segundo Silva ${ }^{103}$ : “ (...) se examinássemos a técnica em todos os seus elementos, e viéssemos a conhecer todos eles, ainda assim a essência da técnica permaneceria oculta. Pois conhecer a técnica como trabalho, instrumento ou meio equivale a visar as determinações antropológicas (valores humanos) que nelas estão contidas, mas que não revelam sua essência."

Neste caso, como dissemos não se pensou ( com a permissão de furtarmos um pouco a expressão de Hannah Arendt):não se pensou na questão metafísica, não se pensou na questão da humanidade ( o que ainda se revela duvidoso,pois nem todos concordam com as respostas) e talvez a imagem que mais tenha falado aos corações (dos católicos) tenha sido a do "ovo órfão"!

A armação, a maneira pela qual a técnica se desvela seria a disponibilidade, "a reunião "originária" de elementos disponíveis, pela qual os entes se apresentam para o homem através d representação calculante da ciência." 104

Heidegger não vê na técnica a perda do humano ou sua alienação, trata-se na verdade do exercício de compreensão da técnica em sua essência.

De fato, o homem cria para si mesmo uma situação temerária, ao se achar

102“Armação significa o modo de desabrigar que impera na essência da técnica moderna e não é propriamente nada de técnico. Ao que é técnico pertence, em contrapartida, tudo o que conhecemos como sendo estruturas, camadas e suportes, e que são peças do que se denomina como sendo uma montagem." HEIDEGGER, M. Opus cit.,p.385.

103SILVA, F.L.Martin Heidegger e a técnica.In:Scientiae studia- Revista Latino- Americana de Filosofia e História da Ciência.São Paulo,v. 5,n³,p.372. 104Ibidem,p. 132. 
"dominador da terra pela via da técnica", ou seja quanto mais este senhorio se valoriza, mais ele se torna disponível, mais ele se torna parte do problema,isto nós podemos verificar em relação ao meio ambiente, isto nós estamos vendo acontecer, no que diz respeito a este estudo,com as técnicas de inseminação artificial, como podemos ver:

“ À proporção que hoje em dia o efeito e a utilidade da ciência se ampliam, desaparecem cada vez mais capacidade e a disposição para a reflexão sobre aquilo que acontece na ciência visto que ela consegue fazer valer o seu propósito de oferecer e administrar a verdade sobre o verdadeiramente real." 105

Segundo Heidegger ${ }^{106}$ quando a ciência é deixada a seu próprio destino ocorre a autodestruição do homem. Este processo tem ocorrido desde o início da ciência moderna:

“A ciência moderna é fundamentada também no fato de que o homem coloca a si mesmo como sujeito determinante para o qual todo ente pesquisável torna-se objeto. Isto,por sua vez,é baseado numa transformação decisiva da essência da verdade para a certeza, em consequência do que o ente verdadeiro assume o caráter de objetividade."107

E não é isto que estamos vendo ocorrer atualmente? O não estar comprometido com a técnica estabelece esta relação de senhorio com a natureza e com a própria técnica. O agente não percebe o caminhar do processo, ludibriado pelo brilho das situações momentâneas,como diria Silva ${ }^{108}$ :“ A princípio, o horizonte de benefícios que se abre a partir dessas descobertas é inegavelmente estimulador de grandes esperanças,principalmente no que concerne à cura e à prevenção de doenças até agora fatais.”

É preciso que se rearticulem os laços entre a atividade científica e a experiência histórica,ou seja, que a descoberta científica seja feita com relação ao interesse da humanidade. Neste sentido, esta relação rearticulada indicaria o próprio caminho da dignidade humana . Ocorre porém um jogo de interesses que se contrapõe a isto: “ $O$ patenteamento dos genes e a expectativa de lucro da grande indústria farmacêutica são interesses despertados pelas descobertas genômicas que se contrapõe à carência de grande parte da humanidade, e à expectativa de benefícios que sejam concretamente partilhados por todos" Está instalado o perigo!

Neste sentido, Marques ${ }^{109}$ :

No mundo empresarial, quando um país interdita uma pesquisa com novas tecnologias, as

105Heidegger,M.Opus cit., p.121.

106“ A essência da técnica repousa na armação. Seu imperar pertence o destino(...) Uma vez levado a estas possibilidades, o homem está, a partir do destino, colocado em perigo. O destino do desabrigamento é, enquanto tal,em todos os seus modos, um perigo, e por isso, necessariamente um perigo." In HEIDEGGER,M. Opus cit, p.389.

107Ibidem

108Silva, F.Genética e Ética.

109 BERNARDES, M. Opus cit.,p.43. 
empresas de outros países ocupam rapidamente a brecha em virtude das exageradas expectativas econômicas que, por enquanto, lhe são atribuídas. A confusa situação da regulação do mundo, aparentemente, não tem diminuído o interesse das empresas privadas. (BERNARDES,M. 2006)

Este jogo de interesses faz com que a saúde e mesmo a vida fiquem muitas vezes relegados a outros planos. Silva conta por exemplo que a África tem $25 \%$ da população infectada com o vírus HIV. Os remédios que compõe o coquetel são todos patenteados e muito caros, uma das empresas multinacionais que patenteou o coquetel se comprometeu a baixar os preços, mas ameaçou acionar judicialmente o governo sul africano quando ele ameaçou fabricar ou importar de outros países o mesmo remédio. Observa-se então, o quanto o interesse econômico se sobrepõe ao interesse da vida e neste sentido Silva ${ }^{110}$ questiona: "Como se pode esperar, nessas condições que uma possível droga eficaz contra o câncer,por exemplo, produzida a partir dos resultados das pesquisas com genoma, seja colocada ao alcance da maioria da população do planeta?

A técnica distanciada de sua essência faz com que o próprio homem se perca também da sua essência.Assim:

“Enquanto este destino, a essência da técnica admite o homem para algo que ele propriamente não consegue a partir de si nem achar e muito menos fazer;pois algo como um homem, que unicamente é homem a partir de si,não existe" (HEIDEGGER).

No desenrolar das ciências modernas o homem se perde de si mesmo e disso resulta a ameça à dignidade que inerente à essência se perde junto com o homem se tornando falácia!

\section{CONCLUSÃO - PARTE II}

Analisando-se a técnica utilizada pelas ciências modernas à luz da questão heideggeriana vemos que, da maneira como se conduz, a única coisa que consegue descobrir são as coisas referentes ao corpo e quanto mais segue este padrão mais se vê distante da essência de seu objeto. Desta forma , obtém "verdades efêmeras que hoje são e amanhã não serão mais, daí a sua precariedade, daí o perigo para o homem. Neste aspecto, quando o homem é tratado apenas em relação ao seu corpo ou ao que pode se medir dele, como falar em dignidade? Onde residiria a dignidade humana?

\section{Parte III- O corpo na política}

\section{7- A reificação do homem- A questão da dignidade}


" Duas mulheres olhavam revistas em um salão de cabeleireiros: -Fulana,encomendei um bebê igualzinho a este aqui, loirinho de olhos azuis, o que você acha?- Ah,respondeu Ciclana: - É muito fofo! Eu também já encomendei um, mas preferi o modelinho padrão, era mais em conta... ( criação da autora)

Tudo caminha- principalmente o corpo- para o artifício. Ou melhor, observamos o início de uma substituição do Ser e de suas experiências de vida- isto é, da antiga relação, em nós, da natureza e do espírito ( espírito entendido como inteligência, potência de transformação)- por mecanismos implantados em nós. $\mathrm{O}$ sentido primordial da palavra natureza é nascor, cuja origem latina quer dizer “ nascer, viver”(NOVAES, A, 2003 ${ }^{111}$ )

O cientificismo característico dos séculos XVII,XVIII e XIX pareceu deslocar o homem de seu lugar. O homem passou a se ver como coisa. Como dissemos anteriormente (capítulo I), a experimentação científica realizada por médicos, biólogos, químicos e físicos (quando tais cientistas não cumulavam todas estas funções), transformou o corpo humano em objeto. ${ }^{112}$ Expressões como Dignidade da pessoa humana se tornaram jargões baratos na esfera política, a impressão que se tem é de que não passa de falácia sob a tutela dos direitos humanos.

A noção de dignidade está atrelada em seu processo histórico ao conceito de pessoa. O conceito de pessoa só viria a aparecer com Boécio. Este estadista e filósofo do séc. IV DC,rediscutiu o dogma de Nicéia, o qual se referia a natureza humana ou divina de Jesus. Para este filósofo, a pessoa é o ser, aquele que molda a matéria, a pessoa seria a substância individual da natureza racional.

Mais tarde encontraremos em, Giovanni Pico della Mirandola, ( filósofo italiano do século $\mathrm{XV}$ ) as primeiras idéias sobre dignidade humana. Como sabemos tal século é caracterizado pelo Renascimento cultural da Europa e por um forte predomínio do pensamento antropocentrista. Em seu "Discurso sobre a Dignidade do Homem" presente em uma obra denominada Oratio, Mirandola articula três níveis de inteligibilidade para atribuir ao homem a sua dignidade, sendo estes níveis: a razão, a liberdade humana e a questão do ser,acabando por implicar na mesma questão a dialética, a ética e a metafísica.

Em seu discurso nota-se uma prevalência da "razão e sua peculiar capacidade

111 NOVAES, A. Prefácio: In: O Homem- Máquina A Ciência manipula o corpo.São Paulo: Companhia das Letras.2003, p.9

112 Jorge Coli, professor de História da Arte da Unicamp, assim dispõe: “ Na virada do século XVIII para o XIX, há um deslocamento do lugar onde se encontra o humano. Surge uma nova configuração, na qual o olhar do homem sobre o homem não é mais sobre si, mas sobre uma coisa. O homem objetiva-se a si mesmo, no sentido de que se dispõe, como objeto, para um sujeito que conhece. Objeto de si, seu corpo se evidencia, apresenta-se como corpo apenas, disposto para a ciência ou para a arte."Coli, J. "O sonho de Frankenstein”. In: “ O Homem- Máquina- A ciência manipula o corpo”, p.299. 
indagatória" como valores intrínsecos ao ser humano. A razão permitiria ao homem tomar sua consciência de liberdade, para Mirandola ${ }^{113}$ : O homem é o ser mais digno da Criação de Deus, porque foi colocado no centro do universo e porque de tudo quanto foi criado ele possui as sementes .

Outra característica do homem, segundo Mirandola, seria a sua liberdade de escolha, o livre-arbítrio ${ }^{114}$. Com esta liberdade, o homem pode ser o que quiser: pode se degenerar ou pode se regenerar até a angelitude, mas estas possibilidades dependem apenas de sua escolha, assim, o homem se torna autor de seu próprio destino. Propõe então a idéia da vontade que deverá ser orientada para o bem. O homem possui o poder de se autodeterminar o que o colocaria acima do mundo físico-biológico, por isto o homem de Mirandola é quase divino, porque feito à semelhança do criador, mas imperfeito em suas ações.

Verificamos que no século XVIII, Kant ${ }^{115}$ viria a continuar o legado de Mirandola. Segundo Kant, o ser racional possui faculdade de agir segundo leis ou princípios: só o ser racional tem vontade. Assim existiriam seres cuja vontade dependeria da natureza: estes seriam chamados coisas, por outro lado os seres racionais seriam as pessoas. Segundo Kant, só a "pessoa" viveria em condições de autonomia. O ser humano é insubstituível, não tem equivalente e não pode ser trocado por coisa alguma. Através de seu trabalho, Kant alargou e aprofundou a dicotomia entre pessoas e coisas oriunda do Direito Romano (persona e res). Relembrando as Institutas de Gaio, o direito era classificado em três categorias: pessoas, coisas e ações. (“ Todo o direito de que usamos ou respeita as pessoas, ou às coisas ou às ações").De acordo com o trabalho de Kant, a dignidade da pessoa humana sai atingida pela escravidão e também, segundo a concepção Kantiana esta mesma dignidade pode também sair lograda por falsas promessas ou atentados contra bens alheios.

Com o advento do pensamento de Marx e principalmente de Lukács nos deparamos com o fenômeno da "cosificação do homem". Na verdade ,Lukács ${ }^{116}$ foi o primeiro a utilizar tal expressão. Conforme a perspectiva demonstrada em Marx e Lukács, a coisificação do ser humano ocorreria por via econômica através da apropriação dos meios de produção. Na estrutura da revolução industrial regida pela ordem da produção em série, o homem perde sua identidade como ser individualizado e passa a ser apenas, mais uma

113 MIRANDOLA, G. P. della. Discurso sobre a Dignidade do homem,p.27.

114 Mirandola foi fortemente influenciado pelo pensamento escolástico durante sua formação como filósofo.

115 KANT, I. Fundamentação da Metafisica dos Costumes e Outros Escritos. São Paulo: Martin Claret, 2006.

116 Lukács, G. Consciência de Classe.Disponível em: www.dominiopublico.gov.br. Acesso em 25/01/2007. 
peça da engrenagem geratriz de bens de consumo. Na visão de Marx o "corpo" humano se reifica pelo fato de que o suor de seu trabalho torna-se garantia de sua sobrevivência: o homem vende as forças de seu corpo para se alimentar.

Como nos ensina Arendt, a maior preocupação do homem tem sido a sua vida de labor. A manutenção da sobrevivência do corpo toma-lhe tanto tempo e energia que mal tem tempo para analisar, sob um certo olhar distanciado, o que está fazendo de sua existência. Como seres humanos, passamos pela vida tentando combater a nossas próprias necessidades vitais, criando coisas num ato contínuo de fabricação para termos mais "necessidades vitais," (o homo faber) sem nos darmos conta de nossa presença neste mundo, o efeito que causamos nele.

Em sua obra "A Condição Humana", Arendt ${ }^{117}$ propõe, entretanto uma fundamental diferença entre a criação humana e a divina. A criação de Deus surge do nada enquanto que a criação humana só é possível mediante destruição, como se encontra no seguinte trecho: (...) Deus cria ex nihilo, o homem cria a partir de determinada substância-, a produtividade humana, por definição resultaria fatalmente numa revolta prometéica pois só pode construir um mundo humano após destruir parte da natureza criada por Deus.

O pensamento filosófico oriental chinês leva-nos, de certa forma, à perspectiva existencialista de Arendt, na medida em que vivemos um eterno ciclo de criação e destruição. Da mesma forma, Jung, em sua perspectiva psicanalítica propõe este mesmo jogo de contrários, como se verifica através das tão conhecidas polaridades: claro e escuro, positivo e negativo, luz e sombra, nascimento e morte. Neste mundo em que estamos, um parece não existir sem o seu contrário. A despeito da "potencialidade" preferimos o fenômeno. Neste aspecto: A vida de um "possível ser-humano" teria mais significado que a de outro já existente? Retornamos à questão do psiquismo...

$\mathrm{Na}$ opinião de Arendt $^{118}$, as imagens mentais do homem seriam passíveis de reificação, mas os sentimentos, as sensações corporais, o desejo, são sensações impossíveis de reificação, como se transcreve:

"O que nos chama a atenção é o verdadeiro abismo que separa todas as sensações corporais, prazer ou dor, desejos e satisfações, - sensações tão "privadas" que não podem ser adequadamente expressas, e portanto, absolutamente impossíveis de reificação- das imagens mentais, tão fácil e naturalmente reificáveis que não podemos conceber uma cama, sem antes, ter alguma "idéia" da cama ante os olhos de nossa mente, nem podemos imaginar uma cama sem recorrer a alguma

117 Arendt, Hannah. Reificação. In: A Condição Humana. $8^{\mathrm{a}}$ ed. Rio de Janeiro: Forense Universitária1997, cap. 19, p. 152.

118 ARENDT,H. Opus cit. p. 154. 
experiência visual de coisas reais.

Para Hannah Arendt, o processo de fazer é determinado pela categoria de meios e fins. Como já dissemos anteriormente neste trabalho, a primeira "finalidade" da geração de embriões, "in-vitro" foi possibilitar que mulheres pudessem gerar filhos em seus próprios úteros, resolver, portanto, um problema de infertilidade, cada vez mais freqüente.

O embrião "in-vitro", desde a sua sua criação já se dirigia à uma finalidade. Sob a perspectiva de $A$ rendt $^{119}$, percebemos que o embrião adquire um caráter finalístico, como vemos: A característica da fabricação é ter um começo definido e um fim definido e previsível, e esta característica é bastante para distinguí-la das outras atividades humanas . Ora, o embrião foi artificialmente criado pela união do espermatozóide com um óvulo em um "pratinho" (início definido), com o fim (definido), em príncípio, de ser introduzido em um útero para que desenvolvesse um bebê.

Diferentemente das atividades de labor, ( segundo Arendt caracterizadas pelos ciclos vitais do corpo) e a vida activa ( manifesta na atividade política do ser humano), o embrião congelado pode ou não vir a nascer, dependendo da sua condição: se inviável ele não será implantado e passará a fazer parte da vida laboral de alguém. Nascendo, ele começa algo novo no mundo ele poderá agir. Entenda-se que estamos falando de possibilidades.

A crítica de Arendt se faz no sentido como tem se dado a vida humana, a biologização das esferas da existência destrói as condições mundanas e plurais da existência. O espaço público foi invadido pelo animal laborans e se tornou uma regra de organização geral. Analisando a obra de Arendt diz Ortega ${ }^{120}$ :

"Se no totalitarismo o poder artificialista da técnica era utilizado para reduzir a humanidade ao fato biológico, nas sociedades liberais modernas recorre-se à mesma artificialidade com objetivo de aumentar o poder do processo vital natural, transformando em norma implícita da vida em comum"

A vitória do "animal laborans" e do caráter sagrado da vida se vinculam à despolitização e ao controle sem medidas da atividade científica.Não é sem razão que o direito também, no que diz respeito as deliberações sobre a célula-tronco se viu forçado ao encaixe cartesiano, melhor explicando é como se fosse um ciclo de precariedades: a ciência delimita a questão e o direito tem que pesar a questão baseado nos postulados científicos que como sabemos não têm condições de práticas seguras e aí tudo parece um jogo de 
equilíbrio sobre o desequilíbrio.

Segundo Arendt, Kant ${ }^{121}$ teria se baseado no utilitarismo antropocêntrico para criar a fórmula, expressão da dignidade humana: Nenhum homem deve jamais tornar-se um meio para um fim, todo ser humano é um fim em si mesmo. Considerando a criação do embrião "in vitro" e sua controvertida utilização para a produção de células e tecidos que podem curar um imenso grupo de pessoas portadoras de doenças intratáveis pelos métodos tradicionais, entendemos que, segundo o pensamento de Hannah Arendt, o embrião foi criado inicialmente para um determinado fim ( a cura da infertilidade), lançado na mundanidade “ do meio científico e laico, perde-se em seu sentido existencial no que tange às considerações biológicas, éticas, jurídicas e políticas, sem falar das econômicas ( talvez as propulsoras mais eficazes do debate). Portanto, se partirmos deste princípio, que o embrião foi criado com uma determinada finalidade, temos duas saídas: ou ele não é humano no sentido de não ter um espírito, ou, considerando-o humano reduzimos o homem apenas à dimensão corporal e tudo o que se acredita em termos de religião: vida após a morte, reencarnação, vida "eterna se esvai: a finitude da vida se dá com a finitude do corpo!

Defensores da tese da humanidade do embrião esquecem-se de que, do outro lado da questão, as pesquisas se dirigem a seres humanos realmente existentes e enfermos, esperançosos de que tais experimentos lhes devolva a "dignidade" de suas vidas, incapacitados que se encontram em sua liberdade de escolha devido à debilidade de seus corpos. Para estes, que talvez nunca tenham estado em tal condição, aconselho um passeio aos hospitais. Apesar da técnica ainda há a esperança.

Em sua obra "Ser e Tempo", Heidegger demonstra a importância da fenomenologia e da ontologia para o entendimento do ser. Heidegger diz que fenomenologia exprime a idéia "às coisas em si mesmas" 122 e conceitualmente diz: (...)deixar e fazer ver por si mesmo aquilo que se mostra, tal como se mostra a partir de si mesmo. ${ }^{123}$ Complementarmente, a ontologia teria como tarefa: (...) apreender o ser dos entes e explicar o próprio $\operatorname{ser}^{124}$. Podemos inferir desta idéia que o pensamento de Heidegger se guia pela fenomenologia como via de investigação despida de idéias pré-concebidas ou conhecimentos superficiais sobre o que se quer estudar, procurando-se desvelar os seres dos entes da maneira como eles de fato se dão. Sobre isto então indagamos: o que é o embrião? Quanto à sua condição de "ser", temos algumas pistas...

121 KANT, I. Opus cit. p.156

122 HEIDEGGER, M. Ser e Tempo. $15^{\mathrm{a}}$ ed. Rio de Janeiro: Editora Vozes, 2005, p.57.

123Ibidem, p. 65.

124Ibidem,p. 56 
O que Heidegger propõe de fato é a "saída de si mesmo" para ver no outro ser ( gente, animais , vegetais, etc...) o reflexo daquilo que fazemos e de como nos comportamos, sabendo que, mesmo que nos coloquemos a par de todas esta mundanidade, ainda assim estaremos atrelados a ela quer queiramos ou não. No que diz respeito ao tema deste trabalho, a própria história revelou as atrocidades cometidas contra os sereshumanos. A própria história, baseando-se no temor, revelou-se no Código de Nüremberg e têm revelado a todo momento as questões pertinentes ao embrião. $\mathrm{O}$ que resta saber é se de fato o vemos como ele é, ou estamos perdidos em um mundo de representações individualistas?

Heideggeriano, neste aspecto compreende a fenomenologia como método de investigação levando em consideração a análise do ser- o- aí (“dasein”),ser no mundo, sercom dentro de seu tempo, refletido em sua historicidade. Cumpre-nos então observar este caminhar científico precário e ver o que vai dar.... Já pensou se os cientistas encontrarem a antimatéria nos homens?

O legado ético de Kant demonstra que a dignidade decorre do fato de não se querer causar sofrimento a outrem, mas, se falamos em sofrimento entramos na esfera do sentimentos. Sentimentos equivalem a emoções e aí retornamos à questão proposta por Hannah Arendt, da impossibilidade de reificação de tais coisas. Para acertarmos isto precisaríamos conhecer com detalhes o grau de sensações do embrião congelado ( se é que há), o que obviamente não será possível afirmar sem pesquisa, mas que pesquisa, sendo que o método só trata das coisas mensuráveis?Além disso, o embrião já está inserido desde a sua criação na vida do animal laborans, é como se ele tivesse sido engolido pela estrutura organizacional da vida.

Como vimos em Pico della Mirandola, a dignidade humana se dá juntamente com a condição essencial de livre-arbítrio. Nesta equação, se assim podemos denominar, temos de um lado um ser criado em laboratório ( que não se sabe ter alma), um "ser humano" na acepção tradicional do conhecimento ( dotado de alma) e um cientista que muitas vezes se esquece de sua condição, tão humana quanto a de seus pacientes, ( instrumento de pesquisa tanto paciente quanto cientista).

Para Arendt, o cientista, a partir do pensamento moderno, pôde se emancipar das preocupações antropocêntricas, ou seja verdadeiramente humanísticas. De fato, o humanismo colocou o homem no centro do Universo considerando-o o ser mais importante. A visão grega era bem diferente: o homem não era diferente de nenhum outro 
ser existente. $\mathrm{Na}$ visão de Arendt, ${ }^{125}$ o cientista se coloca em um mundo a parte, como se estivesse imune de suas próprias descobertas. Tal argumento se baseia no fato de que quando os cientistas descobriram a fissão nuclear, sabiam também dos potenciais destrutivos da bomba atômica, como dispôs:

"O simples fato dos cientistas terem efetuado a fissão do átomo sem qualquer hesitação, assim que souberam como fazê-lo, embora percebessem muito bem as enormes potencialidades destrutivas de sua ação, demonstra que o cientista qua cientista não se incomoda sequer com a sobrevivência da raça humana sobre a terra ou, o que disto decorre, com a sobrevivência do próprio planeta."

O cientista, que também podemos chamar de "técnico" mesmo que imbuído de nobres intenções, parece não ter noção de sua própria fragilidade como ser humano. Notoriamente famoso é o exemplo de Marie Curie ${ }^{126}$ : ganhadora do prêmio Nobel de Química, propôs a aplicação da técnica de radioisótopos para que fosse utilizada na medicina, o que conhecemos hoje por raio-X. A incrível cientista acabou morrendo de leucemia em função de uma grande exposição a estes raios.Pensamos também, no que diz respeito ao pensamento de Arendt que,a formação do estado nazista e a expulsão dos judeus de suas próprias vidas, (não que aí existisse qualquer nobre intenção, longe disso) retrata cruelmente o que a ciência moderna faz movida por " bons princípios de moral e ética".Neste sentido referimo-nos aos achados provisórios, às "descobertas fantásticas" e as coisas que em um primeiro momento parecem com a pílula da eterna juventude!

Neste sentido, Hannah Arendt parece recolocar o homem em sua real dimensão. Fala-nos então de uma proposta geocêntrica atrelada à perspectiva antropomórfica, o que corresponderia melhor às atividades humanas: o homem vive na terra e é mortal. Sob esta visão, tanto os limites dados pelo planeta, quanto aqueles estabelecidos pela precariedade de seus conhecimentos seriam responsáveis por delimitar suas ações.

Semelhante a isto, Heidegger ${ }^{127}$. diz no seguinte trecho: O ser por um outro, contra um outro, sem os outros, o passar ao lado um do outro, o não sentir-se tocado pelos outros são modos possíveis de preocupação(...). Para ele,essa total indiferença e deficiência na percepção das coisas caracteriza um modo de conviver mediano que não pensa sobre os problemas existenciais em que se vive, simplesmente se sobrevive, deixando-se levar pelos acontecimentos num conformismo atávico e indolente. Ainda em outro trecho: Na medida em que a presença é, ela possui o modo de ser da convivência. Esta não pode ser concebida como a

125 ARENDT, Hannah. A Conquista do Espaço e a Estatura Humana. In: Entre o Passado e o Futuro, p. 339.

126 Dados recolhidos do site: http://pt.wikipedia.org/wiki/Marie Curie. Acesso em 28/01/2008.

127 HEIDEGGER, M. Opus cit.p.173. 
soma de vários sujeitos(...). ${ }^{128}$.Esse ser- com” desconsiderado" computa os outros sem "leválos em conta" seriamente, sem " querer " ter algo a ver" com eles.

Sabe-se que foi sob a lembrança dos terrores nazistas, que o Código de Nüremberg se desenvolveu, afinal a Segunda Guerra Mundial, pelos meios mais tortos já vistos, demonstrou que o homem é capaz de destruir a si mesmo de várias maneiras, utilizando-se desde as mais perversas práticas médicas realizadas sem piedade, até o ponto da sofisticação de, ao apertar um botão, destruir vidas humanas há milhares de distância.

Confrontando-se com sua mais nova descoberta, a comunidade científica parece não ter ainda desenvolvido uma perfeita e concreta consciência do que faz, senão não estaríamos às voltas com tantas dúvidas e incertezas a respeito do embrião e tantas outras coisas. Poucos exploraram com maestria a psiquê humana, cujas desordens, quando tratadas de maneira mecânica, abordam a questão em termos de desequilíbrios de neurotransmissores. Disto resultando um medicamento, aqui para depressão, ali para transtornos obsessivos compulsivos, sem se preocupar com a essência do ser e levando o homem a uma total noção de irresponsabilidade sobre si mesmo, afinal qualquer pílula pode dar jeito em seus desatinos, mas não esqueçamos: a ciência só sabe lidar com o corpo, quem quiser conhecer mais terá que lidar com outras noções...

A questão do embrião, desta maneira, demonstra o descompasso entre, o conhecimento humano dado pela ciência no que tange à matéria( corpo) e o que se obtêve em termos de conhecimento científico sobre o espírito. Neste meio caminho, a ética e as leis, mesmo que precariamente, (porque o conhecimento sobre o assunto é precário), tentam delimitar a questão, mas se confrontam com interesses políticos e econômicos.

Neste conflito de interesses, a dignidade da vida humana colocada como princípio norteador de atos sai arranhada, e no que diz respeito à técnica, o próprio técnico se "reifica" pelo fato de se deixar levar sem desocultamento do "caminho", sem se comprometer com o processo,o que, de acordo com Heidegger, pode levar a autodestruição.Neste mundo de corpos a dignidade precisa "corporar",( com a devida licença de Heidegger) para ser percebida, assim como princípio ela parece fumaça de incenso...

Em suma, não se trata mais de verificar a humanidade da célula-tronco embrionária,como vimos , a lógica nos leva a crer que a questão do "humano" só se refira ao material biológico como adjetivo, como quando dizemos,por exemplo: células- tronco embionárias equinas, células- tronco embrionárias bovinas, apenas como caracterização da 
espécie, questão tratada pela taxonomia.

Perguntar sobre a humanidade da célula-tronco embrionária, seria perguntar sobre a possibilidade da alma e isto já vimos com Heidegger que a técnica não permite dizer, visto que seu objeto se dá pelo fenômeno do corporar e também o próprio comportamento do técnico não lhe permite a mudança de paradigmas, e assim o próprio técnico passa a ser objeto da técnica.

Por fim,se ainda restarem dúvidas vimos que a pretensão de humanidade da célulatronco embrionária foi solapada com força de lei: os embriões congelados sob determinadas condições poderão ser utilizados nas pesquisas o que ao nosso ver, considerando-se tempos de "salve-se quem puder", não deixa de ser um saída justa, principalmente no que diz respeito ao senso comum e a todas as perspectivas benéficas propostas. O que notamos é que as ciências modernas ao invés do desocultamento se apresentam como um "atropelamento", em que muitos problemas vão sendo deixados de lado sem solução, assim não se sabe da humanidade do embrião da mesma forma que não se conhece o efeito da terapia em que ele está inserido a longo prazo. No momento a cura ou pelo menos a promessa de cura de certas doenças parece ir às mil maravilhas, mas o homem não é máquina apenas, há que se considerar o fator psiquismo,que como dito Heidegger "é indeterminável. Considerando-se que a "dignidade" não tem corpo, como determiná-la? Que espaço ela teria dentro da questão da técnica? Como definí-la no mundo?

\section{8-Célula-tronco embrionária - $\mathrm{O}$ corpo em juízo}

"Diké andava de um lado para o outro na cozinha do Olimpo: nunca tivera um dilema tão grande para resolver,carregava pra lá e pra cá a balança: de um lado os ovos, do outro galinhas, várias...A dúvida: ambrosia ou "galinha ao molho pardo"? Abriu a geladeira: a ambrosia tinha acabado!Pensou: os ovos então, não foram chocados, melhor conservar as galinhas, elas poriam outros ovos e mais cedo ou mais tarde teriam mesmo que morrer, coisas da vida! Entregou os ovos a Héstia, a tia, velha cozinheira: - Faça a ambrosia! Héstia caprichou e os deuses comeram a melhor ambrosia que já haviam provado..."(criação da autora)

A estorinha acima tem apenas o objetivo de ilustrar a discussão que se deu no Poder Judiciário brasileiro no que diz respeito ao uso dos embriões congelados quanto à realização das pesquisas médicas. Não! De forma alguma estamos comparando ovos de 
galinha a embriões e galinhas a homens (embora os ovos sejam células vivas,possíveis pintinhos se forem chocados, se as condições naturais contribuírem, etc...e galinhas também sejam tão seres vivos quanto os homens!), o que queremos dizer é que a polêmica gerada foi tão grande que vimos um judiciário "espremido" de um lado pelas considerações de ordem moral, ética(?), religiosa, (principalmente religiosa) e do outro pela possibilidade de tratamento ( talvez cura) de doenças graves e até então incuráveis!

O Supremo Tribunal de Justiça teve que decidir entre a incongruência do pensamento católico ( embriões vistos como homens) e seres humanos enfermos! A expressão "dignidade da pessoa humana" virou expressão barata: nunca o pensamento de Hannah Arendt esteve tão presente, nunca Giorgio Agamben teve tanta razão em seu discurso! A medicina, enquanto técnica representada pela voz de renomados cientistas só pôde afirmar que os tais embriões não poderiam ser implantados devido as já presentes alterações em sua condição genéticas ( fora dos padrões de normalidade), nunca viriam a ser homens, demonstrando, como já dissemos, a precariedade da técnica em face de seu próprio técnico!

Restava então resolver o que fazer com eles: - implantá-los em células teciduais para corrigir os defeitos genéticos, "prováveis" causas de doenças ou deixá-los congelados até o descarte, quando então ficaria juramentada a ausência de causa e a falta de comprometimento da técnica! No que pese aos homens enfermos,portadores das mais diversas doenças ( diabetes, alzheimer, mal de parkinson, doenças cardíacas e vários tipos de cânceres) a justiça decidiu pela vida activa, calcada no nascimento e na esperança de melhores condições de vida! Se até então ainda não se sabia o início da vida, coisa que a condição da técnica não conseguiu resolver ainda, embora pensemos que talvez a melhor resposta ainda seja aquela dada pelos espíritos ( porque não excluíram o papel da mulher na gestação, porque nos parece mais lógico...), mesmo respeitando os credos alheios, a justiça humana, mesmo titubeante, resolveu: a vida humana não começa no embrião congelado, fim de papo!Nesta complicada equação sobrou a relação humana entre o homem cientista e o homem enfermos,pólos diferentes da mesma questão que podem ser facilmente invertidos, bastando para isso que ocorram certas contingências de ordem natural!

Em sua obra lições sobre a filosofia política de Kant, Arendt analisando a obra de Kant, "Crítica da faculdade do juízo", diz que o juízo estético apresenta semelhanças com o juízo político. Cabe dizer que Kant faz a distinção entre juízos estéticos e juízos teológicos. O juízo estético é aquele que manifesta em si uma finalidade subjetiva, pois não 
há nada externo que o determine, além de seu próprio juízo, ocorrendo um livre acordo entre as faculdades do entendimento e da imaginação. O que se apresenta para ser julgado é a forma do objeto resultante da atividade reflexiva da imaginação. Neste juízo não há um fim material determinado, pois o objeto não se avalia nem nem por seu uso, nem por qualquer interesse prático, o que há é uma relação emotiva entre o objeto e o sujeito que o julga.

Já no juízo teleológico há uma finalidade objetiva, externa ao juízo que se dá através do condição de um fim natural, o que indica a maneira pela qual o objeto será julgado. Este fim natural é aplicado sobre a natureza da seguinte maneira: primeiro ela recai sobre dois objetos, sendo que um objeto é a causa e o outro o efeito, isto se define como finalidade externa, a segunda forma é aquela cuja finalidade recai sobre um objeto que é causa e efeito de si mesmo, neste aspecto a finalidade é interna. Assim,o juízo teleológico se diferencia do estético pela condição de finalidade externa presente neste último.

O juízo estético espera que todos concordem com ele, neste sentido,o ser que julga deve estar convicto de ter agido segundo uma regra de validade geral. É um juízo calcado no gosto: válido pelo desempenhar da imaginação,pois o sujeito que julga deve se colocar no lugar dos outros: ele imagina todos os juízos possíveis e daí espera a aprovação de seu juízo. O critério para a anuência de todos é apenas o gosto. O juízo estético não se submete ao sentido de verdadeiro ou falso.

Para Arendt, o fato de que, no juízo estético o ser que julga colocar-se no lugar dos outros, mostra que a atividade de julgar, embora seja realizada pelo indivíduo sozinho, somente pode ser feita por um indivíduo que tenha como referência a comunidade de homens.

Este colocar-se no lugar dos outros através da imaginação origina o sensus communis o que, na opinião de Arendt faz do juízo estético de Kant um ato de comunicação por meio de representações.

Segundo Abreu ${ }^{129}$ : “ O sensus communis é um senso comunitário individual, e o indivíduo que exercita seu senso comunitário não pode forçar ninguém a concordar com seu juízo, pode apenas pretender o acordo de todos, por ser o seu juízo portador da validade exemplar." ( Abreu, 2004).

Para Arendt, o juízo estético é análogo ao político, incide sobre um particular mas

129ABREU,Maria Aparecida.Hannah Arendt e os limites do novo.Rio de Janeiro: Azougue editorial, $1^{\mathrm{a}} \mathrm{ed}$, 2004,p.96. 
através do sensus communis pretende ser geral. Este juízo tem a comunicação como referência e não enuncia nenhuma regra ou lei que indique como agir.É um juízo imparcial que leva em consideração os possíveis julgamentos dos outros, sendo portanto também um juízo desinteressado.

Ao contrário, o juízo teleológico não é desinteressado como o juízo estético. $\mathrm{O}$ juízo teleológico está condicionado a uma finalidade externa ao julgar, esta atividade porém pode ser interna ou externa ao objeto do juízo. Para Arendt afastar o juízo teleológico é afastar uma promessa para o futuro. Compreende Arendt que o juízo é a nossa faculdade de lidar com o passado o que lhe parece mais coerente do que vincular a atividade de julgar ao futuro, daí sua preferência pelos juízos estéticos na política.

Arendt também aproveita a distinção feita por Kant em relação aos juízos reflexionantes ou reflexivos e os juízos determinantes que se dão pela articulação entre as faculdades do entendimento, razão e imaginação.

No juízo determinante é dado um "entendimento", uma lei gerada pela razão, neste caso uma das faculdades do juízo é legisladora. Já no juízo reflexionante nada é dado por nenhuma faculdade. Neste tipo de juízo todas as faculdades agem livremente sobre um objeto bruto. O juízo reflexionante permite uma mentalidade alargada pela imaginação e com isto o julgador obtém um enunciado geral, o que, segundo Arendt permitiu a reflexão sobre o totalitarismo dado como evento sem precedentes. Este seria o juízo político por excelência,pois permite que cada evento seja julgado em sua particularidade.

Passando-se ao território das discussões jurídicas sobre a legalização do uso da célula-tronco embrionária em pesquisas vemos que a decisão do Supremo Tribunal Federal deu-se nos moldes políticos do juízo reflexionante com a sensação de cerceamento do imaginar por parte dos julgadores ( receio de cometer injustiças?).Por isso tantas pessoas foram solicitadas: foram ouvidos cientistas, religiosos ( que defendiam o embrião), homens doentes, sociólogos, etc...tudo para se formar uma opinião acertada que acabou por corroborar em um juízo estético com o pleno assentimento de quase todo o sensus communis ( entenda-se povo).

Neste julgamento reflexivo e estético, o juízo se voltou à particularidade ( do homem muito enfermo), com interesse voltado a uma pretensão universal ( mesmo que o caminho técnico ainda esteja sendo trilhado e esteja coberto de armadilhas) e por isto o direito humano à vida falou mais alto em relação aqueles que de fato se mostravam e se mostram vivos. Atores ( os juízes) e espectadores ( os que aguardavam o juízo), dividiram o mesmo espaço. 
Mas e se este juízo estiver errado? (Não pensamos no juízo equivocado em relação aos embriões pois particularmente acreditamos na perfeição de Deus, na designação de espíritos anterior à formação de qualquer corpo, o que também pode ser verificado no pensamento leibniziano expresso na obra "Sistema Novo da Natureza"), além disso a liberação da utilização dos embriões congelados supera de certa forma a questão,ou pelo menos a decapta: “dura lex sed lex”.Mas,repetimos, e se o juízo estiver errado em relação ao homem enfermo?E se a técnica que ainda se delineia não se tiver "desocultado" totalmente e as consequências forem perniciosas?E se daqui cinco anos tais pacientes adoecerem de outras doenças, como se poderá identificar a causa: se ficaram doentes pela técnica ou se ficaram doentes por contingências "naturais", como genes recalcitrantes, genes subversivos?).

Após realizar um ato, o ator não pode voltar e apagar o que foi feito, mesmo que ele resolva revogar o juízo anterior,este novo juízo poderá atenuar os atos futuros mas não poderá apagar o que foi feito e neste caso nos referimos à precariedade da técnica principalmente no que se refere a seu total desocultamento,à sua essência.Qual será, neste caso, a salvaguarda dos homens que se submeterem aos procedimentos desta pesquisa? consentimento informado ( muitas vezes viciado pela vontade do cientista)? Mas como alguém pode informar sobre um caminho que também está trilhando?É como se unissem na mesma viagem "o mais ou menos encontrado" ( o cientista) com o "totalmente desencontrado" ( o homem enfermo)!

Considerando-se a fragilidade da técnica , como estabelecer um juízo "seguro"? Em termos humanos, como dissemos anteriormente, estamos lidando com um objeto capaz de mudar, estamos lidando com o cristal aperiódico e sem precedentes traduzido como gene!

Se tudo der certo, se a técnica funcionar a contento e todos forem curados, ótimo! Mas se as coisas derem errado e novas doenças aparecerem estes mesmos homens se tornarão estatística nos relatos de caso da ciência e então estaremos todos diante da ausência do pensar e da banalidade do mal,não estaremos?

O comportamento quase imbecil de Eichman, durante o julgamento fez com que Arendt ${ }^{130}$ pensasse na questão da ausência de pensamento:

“ Foi a ausência de pensamento - uma experiência tão comum em nossa vida cotidiana, em que dificilmente temos tempo e muito menos desejo de parar e pensar, possível não apenas na ausência de "motivos torpes" ( como a lei os denomina), mas de quaisquer outros motivos, na ausência de qualquer estímulo particular ao interesse ou à volição? Será

130ARENDT, H. A vida do Espírito- O Pensar - O Querer-OJulgar. Rio de Janeiro:Editora Relume Dumará,

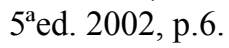


que a maldade- como quer que se defina este estar "determinado a ser vilão" - não é uma condição necessária para o fazer- o -mal?Será possível que o problema do bem e do mal, o problema de nossa faculdade para distinguir o que é certo do que é errado, esteja conectado com nossa faculdade de pensar?"

Ainda sobre a ausência do pensar ${ }^{131}$ :

"A ausência de pensamento com que me defrontei não provinha nem do esquecimento de boas maneiras e bons hábitos, nem da estupidez, no sentido de inabilidade pra compreender- nem mesmo no sentido de "insanidade moral",pois ela era igualmente notória nos casos que nada tinham a ver com as assim chamadas decisões éticas ou os assuntos de consciência".

Também:

“ A questão que se impunha era: seria possível que a atividade do pensamento como tal- o hábito de examinar o que quer que aconteça ou chame a atenção independentemente de resultados e conteúdo específicoestivesse dentre as condições que levam os homens a se absterem de fazer o mal,ou mesmo que ela realmente os "condicione" contra ele ?( A própria palavra "consciência" em todo o caso, aponta nesta direção, uma vez que significa "saber comigo e por mim mesmo", um tipo de conhecimento que é atualizado em todo processo de pensamento)." 132

Referindo-se à técnica:

“ Com o surgimento da Era Moderna, o pensamento tornou-se principalmente um servo da ciência, do conhecimento organizado; e ainda que tenha ganho muito em atividade, segundo a convicção crucial da modernidade pela qual só posso conhecer o que eu mesmo produzo, foi a matemática, a ciência não empírica por excelência, em que o espírito parece lidar apenas consigo mesmo, que passou a ser a ciência das ciências, fornecendo a chave para as leis da natureza e o universo que se encontram ocultas pelas aparências. Se era um axioma para Platão que o olho invisível da alma era órgão adequado para contemplar a verdade invisível com a certeza do conhecimento, tornou-se axiomático para Descartes- durante a famosa noite de sua "revelação"- que havia "um acordo fundamental entre as leis da natureza ( que estão ocultas pelas aparências e por percepções sensoriais enganosas) e as leis da matemática." (Arendt, )

Arendt se refere assim à nossa frágil capacidade de distinguir entre o bem e o mal. No que se tange à utilização da célula-tronco embrionária como meio terapêutico, (remédio), o dilema está formado:ou acudimos aos homens enfermos,ainda que a técnica esteja a caminho, com o intuito de curá-los(?), ou esperamos,e esperando que a técnica se confirme em algo 100\% seguro e eficaz,o tempo poderá se encarregar de decidir entre os que irão morrer ou não, mas não podemos culpar o tempo e neste caso não estaríamos 
errando por omissão? E,se por trás das determinações legais está o Estado então este mesmo Estado passa a ter direito de vida e morte sobre seus cidadãos?

Retornamos assim à condição do homem sagrado:se não fazemos nada o homem enfermo morre por omissão, por ter sido deixado ali ao sabor dos deuses ... se legalizamos a técnica e ela o matar, ele foi sacrificado em nome da divindade representada pela ciência...quando então passa a fazer parte das estatísticas, traduzindo, na maioria das vezes o que não deu certo!

O homem sagrado,homo sacer é uma figura do direito romano arcaico na qual o caráter da sacralidade liga-se pela primeira vez a uma vida humana. O homo sacer é aquele destinado aos deuses: são aqueles homens que a lei determina serem sagrados a uma divindade, mas apesar de sua condição de destinado aos deuses, ele poderia ser morto por qualquer homem. Voltamos assim a condição do tabu: “(...) da inviolabilidade dos ídolos, dos santuários, dos sacerdotes, dos chefes em geral, das coisas e pessoas que pertencem aos deuses e ao seu culto....'(Agamben $\left.{ }^{133}, 2005\right)$.

Os atos governamentais tem fomentado a política da "inclusão", ou seja, o de possibilitar que as minorias tenham igualdade de direitos, o que em um certo sentido parece contraditório: se a política propõe a igualdade é porque admite a desigualdade e de fato, neste caso, se verificaria uma crueldade não proporcionar, ao menos, a possibilidade do tratamento, sabemos porém, seria até ingênuo pensar,que o Poder age apenas visando obter o bem comum. Como se sabe: vivemos em um mundo capitalista e no desenvolvimento de qualquer projeto de pesquisa estão envolvidos os tais aspectos financeiros. Então quando o homem se torna meio em um método científico, mesmo que seja para o "seu próprio bem" não sairia arranhada a dignidade da vida humana?

Uma outra coisa se verifica: se não se permitisse a pesquisa, o Estado estaria contribuindo para a formação de uma nova minoria, a dos "desassistidos da saúde" que passaram então, com a permissão da lei a condição de "cobaias legalizadas", mesmo que os protocolos de pesquisa sejam rigorosíssimos. Se o nosso discurso neste sentido é tão contundente é porque observamos em todas as instâncias da vida o fenômeno da "fama por cinco minutos" onde tudo passa por um momento "fashion", melhor explicando: Na década de 70 a talidomida parecia ser o milagre contra os tradicionais e incomodativos enjôos da gravidez, porém aquela "pilulazinha" aparentemente inofensiva fez nascer uma grande quantidade de crianças com malformações, culpa de quem?Da grávida( que não sabia)? Do médico ( que também não sabia muito bem)? Da indústria farmacêutica(será 
que não sabia)?Em outro sentido, durante anos as pessoas se impressionaram com a leitura sobre o totalitarismo feita por George Orwell em "1984". Hoje o "Grande Irmão" virou um ridículo programa de televisão com absurdos índices de audiência. Talvez tenhamos chegado ao fundo do posso da cultura "fast food"!

Não estamos aqui querendo interromper o curso da ciência e nem impedir as possibilidades de cura(?) de quem quer que seja,mas percebemos que a ciência perdeu a oportunidade de mudar o seu curso ou de pelo menos fazer modificações no método, o que se daria se resolvesse pesquisar também o psiquismo,seja lá de que maneira isto começasse a acontecer: em centros espíritas, em terreiros em práticas de radiestesia, não importa..., o que se ouve por aí é que "isto não é científico" e quem diz isto nunca se despe dos próprios preconceitos do já arraigado método cartesiano.

Vista a questão desta maneira não há como escapar sacralidade de nossas próprias vidas enganados o tempo todo por coisas que são e que dali a pouco não serão mais!

\section{9-O Retorno ao sacro}

Partindo-se da análise dos capítulos anteriores podemos perceber que a ciência atrelada à economia e à política desenvolveu-se de tal forma que perdeu o controle sobre si mesma, e principalmente no que tange às experimentações médicas parece apenas encontrar uma frágil delimitação nos ditos princípios ético-jurídicos estabelecidos. Mas a ciência não se desenvolve sozinha ela é feita por homens de ciência que, imbuídos ou não de tais princípios, continuam a realizar as pesquisas, ora favorecidos pelas perspectivas econômicas, ora favorecidos pelos apoios políticos, ou ambos.

Quase vinte anos antes,(1979), Foucault ${ }^{134}$ propôs:

"Minha hipótese é que com o capitalismo não se deu a passagem de uma medicina coletiva para uma medicina privada, mas justamente o contrário: que o capitalismo, desenvolvendo-se em fins do século XVIII e início do XIX, socializou um primeiro objeto que foi o corpo enquanto força de produção, força de trabalho. $\mathrm{O}$ controle da sociedade sobre os indivíduos não se opera simplesmente pela consciência ou ideologia, mas começa no corpo. Foi no biológico, no somático, no corporal que, antes de tudo, investiu a sociedade capitalista. O corpo é uma realidade biopolítica. A medicina é uma estratégia biopolítica. ( FOUCAULT, M.1979)

Foucault parecia prever o que está acontecendo hoje:Apesar dos defensores da dignidade humana, o corpo parece ter se tornado propriedade da ciência, da economia e da 
política. Neste aspecto, o direito configurado nas legislações éticas agem mais sobre os efeitos do que sobre as causas: legisla sobre algo que não compreende muito bem o que é, nem no que irá resultar.

A idéia de senso comum parece caminhar miticamente em um faixa que varia entre o mal total e o bem extremo perdendo-se entre os efeitos sem levar em consideração a causa de tudo isto: o próprio homem.

Recordando-nos do mito de Prometeu, ao entregar o fogo divino ao homem, estava entregando-lhe um dom. Com esse dom, o homem assegurou sua superioridade sobre todos os animais. O fogo lhe forneceu o meio de cultivar a terra; aquecer sua morada, de maneira a tornar-se relativamente independente do clima, e finalmente, criar a arte da cunhagem de moedas, que ampliou e facilitou o comércio.( BULFINCH, T.). ${ }^{135}$

Observando-se o mito fica claro que o fogo divino trazido por Prometeu corresponde metaforicamente ao conhecimento. Mas, o conhecimento assim adquirido vem acompanhado de uma punição: por esta razão Prometeu foi acorrentado e uma águia devorava-lhe todos os dias o "fígado imortal", que se recompunha, durante a noite. ${ }^{136}$

A noção de punição atrelada à aquisição de conhecimento também aparece no mito bíblico da Árvore do Bem e do Mal ( em algumas versões chamada de "Árvore da Vida" ou "Árvore do Conhecimento") . Assim, por terem comido do fruto da árvore sagrada, Adão e Eva foram expulsos por Deus do Paraíso sentenciados a sofrerem outras penas entre elas, trabalhar, sentirem dor, amaldiçoando-os a eles bem como à sua descendência ( Gênesis)

Para Rousseau ${ }^{137}$ as ciências nasceram dos nossos vícios, ou seja: A astronomia nasceu da superstição; a eloqüência, da ambição, do ódio, da lisonja, da mentira; a geometria, da avareza; a física, de uma vã curiosidade; todas, até mesmo a moral, do orgulho humano(...).

A ciência, como podemos observar, trilha caminhos desconhecidos. O homem como autor e objeto do mesmo ato, demonstra, pelo considerável número de diplomas legais presentes no planeta, que parece ter uma parca consciência do que faz. Como já dissemos anteriormente, o próprio cientista parece olhar o mundo como se não fizesse parte dele, acaba desta maneira, colhendo resultados inesperados com os quais não sabe

135 BULFINCH, T. Opus cit.p,20.

136 HESÍODO, Teogonia, 521s; Os Trabalhos e os Dias, 56. Apud: ELIADE,Mircea. História das Crenças e das Idéias Religiosas- Da Idade da pedra aos Mistérios de Elêusis. $2^{\mathrm{a}}$ ed.Rio de Janeiro: Zahar Editores, 1983, p.87).

137 ROUSSEAU, J-J. Discurso sobre as Ciências e as Artes. São Paulo: Martins Fontes, 1993, p.23. 
lidar, isto só demonstra que além de não ter a exata consciência, o homem não tem também conhecimento da noção exata de bem e mal. Como ilustra Rousseau ${ }^{138}$ :

"Quantos perigos! Quantas estradas erradas na investigação das ciências! Por quantos erros, mil vezes mais perigosos do que é útil a verdade, não é preciso passar para chegar a ela! A desvantagem é visível, pois o falso é suscetível de uma infinidade de combinações; mas a verdade tem apenas uma maneira de ser. Quem aliás a procura com toda a sinceridade? Ainda: (...) Se nossas ciências são vãs no objetivo a que se propõem, são mais perigosas ainda pelo efeito que produzem(...) ( Rousseau, 1750).

E não é justamente disto que trata esta discussão, dos temores decorrentes de uma "quimera" inventada pelo homem de ciência, a qual ele chama de humana sem ter absoluta certeza disto?

Deixando-se de lado a indignação de Rousseau e seus tradicionais incentivos à simplicidade da vida, mantenhamos o foco no desenrolar da questão do embrião frente às considerações políticas, econômicas e jurídicas. De fato, todas estas questões parece-nos emaranhadas, atreladas umas as outras. A descoberta do embrião ultrapassou os limites das ciências médicas biológicas e, segundo grande parte do pensamento filosófico desenvolvido no século XX não se pode falar em corpo humano sem deixarmos de mencionar a técnica e tudo isto como objeto do biopoder ou da biopolítica.

Foucault identifica e descreve o biopoder em duas dimensões: uma diz respeito à maneira como a política administra a parcelaridade de corpos humanos identificados como máquinas, de outro lado o corpo humano é considerado representante máximo da espécie, sofrendo assim as ações das normatizações, o que nos leva à idéia de ser o genoma humano, patrimônio da humanidade, conforme verificamos:

(...) temos, desde o século XVIII ( ou em todo caso desde o fim do século XVII), duas tecnologias de poder que são introduzidas com certa defasagem cronológica e que são sobrepostas. Uma técnica que é , pois disciplinar; é centrada no corpo, produz efeitos individualizantes, manipula o corpo como foco de forças que é preciso tornar úteis e dóceis ao mesmo tempo. E de outro lado, temos uma tecnologia que, por sua vez, é centrada não no corpo, mas na vida; uma tecnologia que agrupa os efeitos de massa próprios de uma população, que procura controlar a série de eventos fortuitos que podem ocorrer numa massa viva; uma tecnologia que procura controlar ( eventualmente modificar) a probabilidade desses eventos, em todo caso, compensar seus efeitos (Foucault, 1979)

Este debate proposto por Foucault ${ }^{139}$, tem por escopo salientar o impacto, no campo político, dos avanços tecnológicos, tentando demonstrar como se relacionam no campo da

138 Ibidem, p.24.

139 FOUCAULT, M. O Corpo dos Condenados. In:Vigiar e Punir. 24a ed. Rio de Janeiro: Vozes, 2001, cap.I, p.25-26. 
vida: corpos, estratégias de poder e capitalismo.

Em sua obra: "Vigiar e Punir"140 encontramos:

"Este investimento político do corpo está ligado, segundo relações complexas e recíprocas, à sua utilização econômica; é uma boa proporção, como força de produção que o corpo é investido por relações de poder e de dominação; mas em compensação sua constituição como força de trabalho só é possível se ele está preso num sistema de sujeição ( onde a necessidade é também um instrumento político cuidadosamente organizado, calculado utilizado): o corpo só se torna útil se é ao mesmo tempo corpo produtivo e corpo submisso." ( FOUCAULT, 1975)

Segundo Foucault, a atuação de poder sobre os corpos (denominada de biopoder) se daria de duas maneiras: através de técnicas que teriam por objetivo o treinamento "ortopédico" dos corpos, as disciplinas e o poder de disciplinar, ou o corpo entendido como pertencente a uma espécie (população) com suas leis e regularidades. Como se dispõe:

" O corpo humano entra numa maquinaria de poder que o esquadrinha, o desarticula e o recompõe. Uma "anatomia política", que é também igualmente uma "mecânica" do poder, está nascendo; ela define como se pode ter domínio sobre o corpo dos outros, não simplesmente para que façam o que se quer, mas para que operem como se quer, com as técnicas, segundo a rapidez e a eficácia que se determina. A disciplina fabrica assim corpos submissos e exercitados, corpos "dóceis".(Foucault)

Neste aspecto, basta que nos recordemos do trabalho mecânico exercido pelos operários, tão bem exemplificado em "Tempos Modernos" de Chaplin: A produção em série das fábricas levou inclusive ao um estudo sobre a decomposição dos movimentos do corpo para que o operário pudesse trabalhar mais rápido, o que ficou conhecido como “taylorismo".Hoje, apesar da proibição , a produção em série de corpos embrionários talvez possa talvez possa levar à condição da gravidez "in vitro".

Para ilustrar a maneira como se dá esta educação disciplinar do corpo, Foucault se refere a figura do Panóptico de Bentham ( precursor do pensamento utilitarista). O Panóptico de Bentahm é uma figura arquitetônica descrita da seguinte maneira:

(...)na periferia uma construção em anel;no centro, uma torre; esta é vazada de largas janelas que se abrem sobre a face interna do anel; a construção periférica é dividida em celas, cada uma atravessando toda a espessura da construção;elas têm duas janelas, uma para o interior, correspondendo às janelas da torre; outra, que dá para o exterior, permite que a luz atravesse a cela de lado a lado. Basta então colocar um vigia na torre central, e, em cada cela trancar um louco, um doente, um condenado, um operário ou um escolar. Pelo efeito da contraluz, pode-se perceber da torre, recortando-se exatamente sobre a claridade, as 
pequenas silhuetas cativas nas celas da periferia. Tantas jaulas, tantos pequenos teatros, em que cada ator está sozinho, perfeitamente individualizado e constantemente visível. $\mathrm{O}$ dispositivo panóptico organiza unidades espaciais que permitem ver sem parar e reconhecer imediatamente. Em suma, o princípio da masmorra é invertido;ou antes, de suas três funções- trancar, privar da luz e esconder- só se conserva a primeira e suprimem-se as outras duas.( FOUCAULT,M. 1975).

Foucault, ${ }^{141}$ não sabe dizer se Bentham inspirou seu projeto no zoológico de le Vaux. O que se verifica é que o Panóptico é um zoológico de homens, com certas particularidades que serão aplicadas conforme as intenções: se forem homens doentes, a construção ajuda a observar melhor os doentes, sem a possibilidade de contágio; se forem crianças, pode-se observar o desempenho escolar, o ou seja, a finalidade do panóptico é dada pela finalidade a que se destina o homem pelos instrumentos determinados pelo Estado.

O que mais nos assusta é que talvez o Panóptico já tenha sido trazido para dentro dos lares, sob o nome de "internet". Ainda que se regule o seu uso, estamos expostos à vigilância por onde quer que andemos.

Como dissemos anteriormente, defensores da dignidade humana pressupostamente presente no embrião parecem não se dar conta do estado geral das coisas: se por um lado cercam o embrião de estatutos e discursos moralistas, por outro,esquecem-se de sua própria condição existencial. Se antes o panóptico estava associado a estruturas físicas de controle e poder podemos redimensioná-lo às quatro paredes de um laboratório,local onde atualmente se dá o controle celular humano.

Procuramos ao longo desta pesquisa descobrir a humanidade da célula-tronco e acabamos descobrindo que o homem que defende esta suposta humanidade não sabe nem da sua própria. Na verdade encontramos a precariedade das ciências modernas endurecidas pela técnica e um domínio quase divino do método, e falar de direitos humanos parece abordar a questão pela via metafísica e como diz Heidegger: não se pode determinar, não tem corpo mensurável,então como materializar o que não se pode determinar?

O discurso propalado pelos direitos humanos calca-se em valores e princípios: liberdade, segurança, dignidade da vida humana, etc..., que parecem existir em uma zona límbica visíveis apenas quando são lesados: na forma de prevenção, ou seja, como bens assegurados e inerentes à própria vida humana, não passam de falácia, como defende Jacques D'Hondt ( direitos humanos como símbolo) e Giorgio Agamben, ( que direitos humanos?). 
No redemoinho dos interesses econômicos e políticos, tanto embrião quanto homem em si perdem esta noção um tanto "santificada" que tantos querem acreditar existir e completamente desconstruída por Agamben quando da questão do homem sagrado.

A condição sacra do homem ( intocável por ser destinado aos deuses) não significa imunidade: este ser, ao mesmo tempo que tem sua vida destinada aos deuses, poderá ser morto por qualquer um e,aquele que matá-lo estará livre de qualquer imputabilidade. A lógica nos diz que a sacralidade deveria lhe fornecer uma determinada proteção, mas neste caso, o sacro parece se referir aos antigos ritos religiosos em que pessoas eram sacrificadas para agradar aos deuses. Na opinião de $\operatorname{Agamben}^{142}$, a "sacratio" é : Uma figura autônoma que permitiria por acaso lançar luz sobre uma estrutura política originária, que tem seu lugar em uma zona que precede a distinção entre sacro e profano, entre religioso e jurídico.( AGAMBEN, G. 2002)

Em sua obra "Profanações", Agamben" ${ }^{143}$ alude à questão do capitalismo transformado em religião, então:

"Onde o sacrifício marcava a passagem do profano ao sagrado e do sagrado ao profano, está agora um único, multiforme e incessante processo de separação, que investe toda coisa, todo lugar, toda atividade humana para dividí-la por si mesma e é totalmente indiferente à cisão sagrado/profano, divino/humano. $\mathrm{Na}$ sua forma extrema, a religião capitalista, realiza a pura forma de separação, sem mais nada a separar. Uma profanação absoluta e sem resíduos coincide agora com uma consagração igualmente vazia e integral. E como na mercadoria, a separação faz parte da própria forma do objeto que se distingue em valor de uso e valor de troca e se transforma em fetiche inapreensível, assim agora tudo o que é feito, produzido e vivido- também o corpo humano, também a sexualidade, também a linguagem- acaba sendo dividido por si mesmo e deslocado para uma esfera separada que já não define nenhuma divisão substancial e na qual todo uso se torna duravelmente impossível. Esta esfera é o consumo."

Por aí se vai o corpo consumido, quer seja célula-embrionária, cientista ou homem enfermo, todos fazem parte do mesmo sistema de consumo do capitalismo.

No aspecto jurídico Giorgio Agamben atrela a noção de sacralidade à questão da soberania. O Povo é soberano, e em seu nome os Estados proclamam a maior parte das Constituições, mas de tão soberano, e aqui no sentido de sagrado, fica à margem do que seria necessário à sua sobrevivência ( alimentação, saúde e lazer, educação, etc...), assim, utilizando-se da figura faminta do homem de Ruanda ( como se não tivéssemos esta mesmo exemplo no Brasil), Agamben ${ }^{144}$ personifica o homo sacer, ou seja, alguém alí 
deixado à mercê da vontade divina, como se dispõe: “É suficiente um olhar sobre as recentes campanhas campanhas publicitárias para a arrecadação de fundos para os refugiados de Ruanda, para dar-se conta de que a vida humana é aqui considerada ( e existem aí certamente boas razões para isto) exclusivamente como vida sacra, ou seja, matável e insacrificável, e somente como tal feita objeto de ajuda e proteção." ( AGAMBEN, G. 2002).

Apesar da "Declaração dos Direitos do Homem e do Cidadão" de 1789, o pensamento político existencialista diz que esta figura, "homem e cidadão" é alguém que não existe. Para Hannah Arendt, a concepção de direitos humanos baseada na existência de um ser humano cidadão, ( aqui no sentido de vida de ação, ou seja, político), caiu por terra. O homem- cidadão, político da Grécia, não existe mais.

Como diz Agamben ${ }^{145}$ :

"É chegado o momento de cessar de ver as declarações de direitos como proclamações gratuitas de valores eternos metajurídicos, que tendem ( na verdade sem muito sucesso ) a vincular o legislador ao respeito pelos princípios éticos eternos, para então considerá-las de acordo com aquela que é a sua função histórica real na formação do moderno EstadoNação."

Transpondo estas idéias para o terreno da ciência, podemos perceber que tanto embrião quanto homem se encontram nesta posição sacra de existência. O embrião porque está na mira dos interesses econômicos como objeto de pesquisa; o homem porque consegue ser ao mesmo tempo objeto de estudo e causa final a mercê da divindade científica.

Desde a Declaração dos Direitos do Homem e do Cidadão pôde-se verificar que grande parte das Constituições e Cartas Maiores dos Estados do mundo, preocuparamse em incluir tais direitos como princípios e garantias fundamentais à vida. Valores como liberdade e igualdade, foram tratados como condição sem a qual não é possível a dignidade humana. Observa-se porém que a dignidade só pode se manifestar pela disposição do capital, sem isto, até a liberdade de ir e vir fica restrita às forças das próprias pernas. Se a dignidade humana se manifesta através das condições de vida permitidas pelo capital então esta dignidade é variável, variando com ela o sofrimento (maior ou menor) em acordo com as posições financeiras. 
Assim, por mais que a lei e a religião cristã tentem vender a idéia de que somos todos iguais ,o que verificamos na realidade é o fato de estarmos imersos em um mar de desigualdades na maioria das vezes estabelecidas pelo poder de compra, ou a propriedade de cada um. Então como defendermos a dignidade humana se, de acordo com a técnica, não conseguimos determiná-la?Onde a dignidade se verifica quando o próprio corpo humano se apresenta como consumo?

Sabe-se que grande parte da população mundial (tenha-se neste sentido como exemplo a África e nosso sertão nordestino) padece de doenças decorrentes da falta de alimentação. A saúde que se espera ver estabelecida e fomentada pelos Estados junto aos povos não corresponde ao que deveria ser: morre-se por falta de atendimento devido à super-lotação dos hospitais. Parece-nos paradoxal que tais problemas ocorram frente ao que se tem por evolução tecnológica. O que ocorre é que: discute-se a vida do embrião préimplantatório sob a carapaça da dignidade,mas sua existência fenomenológica se dá por interesses econômicos, às vezes muito mais do que "pela vontade de curar', de tal maneira que, mesmo que haja a proibição legal em um determinado país sobre o desenvolvimento da pesquisa em tais embriões, um outro país independentemente de quaisquer pareceres éticos e morais, através do fomento da tecnologia poderá transformar o assunto apenas numa questão de patentes.

Por fim, o cenário que se apresenta demonstra que aquilo que se tem por dignidade humana repetimos precisa ser materializada para que possa fazer parte do mundo mensurável da técnica.Se existe alguma maneira de que ela se materialize, esta maneira é aquilo que chamamos condições dignas que se resumem em ter casa, comida, trabalho, transporte, escola, assistência médica igual para todos. Se isto ainda não ocorre é porque ela ainda faz parte do mundo das idéias. Kant a descrevia através do não desejo de causar sofrimento a outrem",mas e quando esta noção de sofrimento vem calcada na ausência de pensamento, melhor explicando, se não se sabe ao certo o "se" das pesquisas, se não se pensa antes?Voltamos as estatísticas...e a história um dia poderá dizer: 
"No ínício do século XXI os cientistas desenvolveram técnicas terapêuticas que a princípio pareciam fantásticas: faziam das células crescerem tecidos novos, alguns, submetidos a esta técnica se curavam, outros,porém, não! O selecionamento de genes permitia que os pais escolhessem cada característica física de seus filhos, havia a impressão de que os homens enquanto espécie haviam melhorado do ponto de vista genético! Com a ocorrência dos cataclismas no final do mesmo século, grande parte dos selecionados geneticamente em laboratório sucumbiram: seus genes estavam "enquadrados" em padrões fixos....ao contrário, os homens que sempre viveram em contato com o ambiente, desenvolveram genes mutáveis, adaptáveis e sobreviveram às catástrofes. Impressionados com a capacidade mutante dos genes, os cientistas resolveram pesquisar os corpos destes homens e não entenderam aquela flexibilidade genética: a maioria destes homens eram místicos, então os cientistas desconfiaram que havia alguma coisa em comum,perguntaram: - Por que os senhores não adoeceram, não morreram? Os místicos responderam:-Aprendemos a controlar os átomos com a disciplina da mente! Os cientistas insistiram: - Como: Eles responderam:- Meditando meus filhos,meditando..." (criação da autora) 


\section{CONCLUSÃO}

Quando comecei a pesquisar sobre a célula-tronco embrionária tinha a idéia inicial de defender a sua utilização nas pesquisas. Importava então descobrir o que isto significava no mundo. Importava descobrir por que a religião se comportava de uma ou de outra maneira. Importava descobrir o que a física e a biologia diziam sobre o início da vida. Percebi que ingenuamente estava tratando a questão de um ponto de vista finalístico: o tratamento de doenças difíceis de curar pelas vias comuns.

Já na conclusão da parte I nota-se a deficiência da técnica científica: tanto na física,quanto na biologia seus postulados não podem ser provados: exigem alguma coisa que a própria técnica, da maneira como vai, não proporciona. Também verificou-se que a religião e sua força simbólica determinavam a condição de existência deste embrião neste Universo mítico: o embrião corresponde ao "ovo", a partícula primordial de criação do Universo e da vida no planeta: com um simbolismo tão impressionante torna-se difícil não confundir as coisas, afinal, estamos falando do ovo humano. Daí o argumento contrário,mas percebemos que a própria argumentação de contradiz: a alma é anterior ao corpo e a crueldade não é atributo divino: Deus não colocaria uma alma em um corpo de embrião congelado, a não ser que fosse uma espécie de castigo ou expiação, mas não podemos questionar a perfeição de Deus, e, considerando-se a pré-existência da alma, esta se sobreporia ao corpo.

Ao longo do caminho as noções foram se modificando: Era necessário descobrir sobre sua condição humana, se é que isto realmente existia. Junto a esta condição humana havia a da dignidade. A princípio parecia uma luta de sobrevivência entre o homem e o seu próprio ovo.

Com a legalização, a liberação dos embriões congelados para sua utilização em pesquisa, qualquer discussão sobre a vida, a dignidade, alma ou quaisquer outras noções metafísicas pareceram escoar pelo ralo. Então percebemos que a própria técnica, ou seja, a condição técnica das ciências modernas já haviam se encarregado de transformá-la em material biológico, em objeto de estudo, mais ainda: conforme o alerta de Heidegger, a técnica, da maneira como tem se dado perde-se de sua essência: a técnica se refere apenas ao corpo, mas o homem não é só isto, então como conhecer sua alma? Como conhecer as relações entre a alma e o corpo se isto não pode ser explicado pelas vias das ciências modernas? Restava então situar o homem nesta equação.

Analisar o problema sob a perspectiva finalista, como dissemos, revelou-se um 
caminho inútil, explicando: apesar do entusiasmo presente entre médicos e pesquisadores bem como entre as pessoas que já passaram pela terapia e tiveram bons resultados, a técnica se mostra como um caminho ainda em seu início tornando-se temerária a emissão de qualquer opinião a respeito. Quando vimos só havia restado o homem preso a seus próprio valores, o homem preso a uma armadilha científica e econômica onde tudo resulta em uma finalidade de consumo. Mesmo que queiramos libertar o embrião de sua condição de uso, os primeiros foram utilizados para gerarem filhos, mas infelizmente a sua condição humana não os liberta da situação de consumo, o que leva a questão da reificação do homem.

O cenário que se verifica é caótico: na equação cartesiana propalada pelas ciências tudo se torna consumo: embrião, homem enfermo, cientista, como os ovos, a galinha e a cozinheira, todos fazem parte do mesmo processo.

Com pesar, acabamos verificando que nada é certo ou seguro: o início da vida? Tanto na Física quanto na Biologia, ninguém sabe precisar. A religião tentou conferir sacralidade ao embrião e, tentando impedir as pesquisas acabando por colocar, na região da sacralidade, os homens enfermos, infringindo o lema máximo da caridade.

Concluiu-se então que a técnica, analisada da maneira como está, tem levado tudo de roldão: embrião, homem e cientistas se confundem em causas do mesmo processo e mesmo assim esta noção precária rege praticamente o caminhar de todas as ciências do mundo. O Direito também calcado na precariedade de tais noções só pode contar com uma coisa: a efemeridade de seus postulados, visto que o caminhar científico é constantemente acompanhado por mudanças em seus aspectos.

A filosofia existencialista de Heidegger compreende uma nova visão para as coisas, mas a ciência nem sabe por onde começar no que define como:antimatéria,coisa que, obviamente, não cabem dentro das equações matemáticas padronizadas.

A situação que se verifica parece um tecido esgarçado: tenta-se consertar um rasgo aqui,mas logo adiante surgirá outro,isto tudo porque o homem deixou de pensar.

Caso pudéssemos sugerir algo, falaríamos sobre a necessidade de mudança de paradigma que se faz necessária principalmente em relação à técnica,mas reconheço minha pequenez. Como vimos o paradigma científico atual associado ao capitalismo se constitui em ameaça, perigo constante. Neste sentido as legislações fazem o que podem mas só alcançam a noção de bem comum pelos olhos das ciências modernas e o ciclo permanece fechado: o que se tem como certo e justo hoje poderá se transformar em dor e sofrimento amanhã e se pudéssemos traduzir tudo isto, talvez a palavra seja:precariedade. 
Como,então,modificar um paradigma arraigado há tanto tempo? Situamos a mudança de paradigma na inclusão do estudo do aspecto psíquico no território científico, mas como fazer isto?Não sabemos ainda, mas acreditamos que esta seria a cura das curas! 


\section{Referências Bibliográficas}

ABREU, Maria Aparecida. Hannah Arendt e os Limites do Novo.Rio de Janeiro:Azougue Editorial, 2004.

AGAMBEN, Giorgio.

-Homo Sacer. Belo Horizonte: Editora da UFMG, 2004.

-Profanações. Belo Horizonte: Editora da UFMG, 2007.

-Estado de Exceção. Belo Horizonte:Editorial Boitempo, 2003.

ARENDT, Hannah

- Entre o Passado e o Futuro. São Paulo: Perspectiva, 6aed.,2007.

- A Condição Humana. São Paulo: Perspectiva, 6 ed.,2007.

- A Vida do Espírito- O Pensar-O Querer-O julgar. Rio de

Janeiro:Relume Dumará,5ª ed,2002.

-Eichman em Jerusalém - Um relato sobre a banalidade do mal. São

Paulo: Companhia das Letras, $7^{\mathrm{a}}$ reimpressão, 2007.

BÍBLIA SAGRADA.Rio de Janeiro: Enciclopédia Britânica, 1980

BRANDÃO, Junito de Souza. Mitologia Grega.Petrópolis: Editora Vozes,12aed, 2002, cap.VI.

BULFINCH, Thomas. O livro de Ouro da Mitologia. São Paulo: Ediouro, 2a ed.,1996.

CAMPBELL, Joseph.

-O Poder do Mito.São Paulo: Palas Atena, 21ªed.1993.

-A Imagem Mítica. Campinas: Papirus, 1994.

-Mitos, Sonhos e Religião nas artes, na filosofia e na vida

contemporânea. Rio de Janeiro:Ediouro, 2001.

CASTIGLIONI, Arturo. História da Medicina.São Paulo: Companhia Editora Nacional, vols. I e II,1947.

DARWIN

-Origem das Espécies. São Paulo: Martin Claret, 2004.

- A Origem do Homem. Belo Horizonte: Itatiaia Editora, 2004.

DESCARTES, René.

-Discurso do Método. São Paulo: Pensamento, 1991

-Discurso do Método e Tratado das Paixões da Alma. Lisboa: 
Coleção Clássicos Sá da Costa, $2^{\mathrm{a} e d ., ~} 1943$.

-Princípios da Filosofia. Lisboa: Ediçoes 70, 1997.

D’HONDT, Jacques. Le refus des droits de l'homme. Les Études Philosophiques. Puf, 1986, p.218-226.

ELIADE,Mircea.

-História das Crenças e das Idéias Religiosas.Rio de Janeiro: Zahar Editores, $2^{\mathrm{a} e d .,}$ 1983,tomo I, vol.2.

-Mitos, Sonhos e Mistérios. São Paulo:Edições 70.

-Mito e Realidade. São Paulo: Ed. Perspectiva, $6^{\mathrm{a}} \mathrm{ed}$.

- O Sagrado e o Profano. São Paulo: Matins Fontes, $1^{\mathrm{a} e d}, 2001$.

FOUCAULT, Michel. Vigiar e Punir. Petrópolis: Vozes, 24a ed., 2001.

GOULD, Jay. O que é vida como um problema histórico. In: Darwin e os grandes Enigmas da Vida. São Paulo: Martins Fontes, 2ªed, 1999

GORDON, Raim e Rivca. "Heidegger on Truth and Myth- A rejection of Postmodernism Phenomenology \& Literature: Peter Lang Publishing. New York.2006.

HEIDEGGER, Martin. $\quad$-A Questão da Técnica.In: Scientiae Studia: Revista Latino Americana de Filosofia e História da Ciência. São Paulo, v. $5, n^{\circ} 3, p .375-399$

-Ser e Tempo. São Paulo: Vozes, 15a ed, 2005.

-Seminários de Zollikon. Petrópolis: Vozes,2001.

KANT, Immanuel. Fundamentação da Metafísica dos Costumes e Outros Escritos. São Paulo: Martin Claret.

KARDEC, Allan. O Livro dos Espíritos. São Paulo: Opus Editora, 3ªed. 1982.

KELEMAN,S.Mito e Corpo - uma conversa com Joseph Campbell.São Paulo: Summus Editorial Limitada, 1999.

KÜNG, H. O Princípio d Todas as Coisas- Ciências Naturais e Religião. Petrópolos: Ed. Vozes, 2005.

LANG, J. "Prometeu e Pandora".Mitos Universais- Mitos e Lendas dos Povos Eeuropeus. São Paulo: Landy, 2002.

LEFORT, Claude. Direitos do homem e política, in “A Invenção democrática”, p.37-69.

LEVI-STRAUSS,C.Mito e Significado.University of Toronto Press, 1978. 
McLESTER,ALee.História Geológica da Vida.São Paulo:Edgard Blucher, 1ªed.1971,cap.1. MARQUES, Jordino. Descartes e sua concepção de Homem- Com uma tradução do Tratado do Homem. São Paulo: Edições Loyola.

MARCONDES,Danilo. Textos Básicos de Ética- De Platão a Foucault.Rio de Janeiro: Zahar. $2^{\mathrm{a}}$ ed. 2007.

MARGULIS, Lyin e SAGAN, Dorion. O que é vida?. Rio de Janeiro: Jorge Zahar Editor. 2002

MARX, Karl. A Questão judaica.São Paulo: Editora Moraes. 1991.

MIRANDOLA, Giovanni Pico Della. Discurso Sobre a Dignidade do Homem. Portugal: Edições 70, 1989.

MOORE, K.L.Embriologia Básica.São Paulo: Elsevier,7ªed, 2008, cap.3,4,5.

NOVAES, Adauto(org.). O Homem Máquina- A ciência Manipula o Corpo. São Paulo: Companhia das Letras.2003.

ORTEGA, Francisco. “ Origem do totalitarismo ( 50 anos depois). Rio de Janeiro: Relume Dumará, 2001, p.81

PLATÃO. Timeu e Crítias ou A Atlântida. São Paulo:Hemus.1998.

RIBEIRO, Márcia Moisés. A Ciência dos Trópicos- A arte médica no Brasil do século XVIII. São Paulo: Editora Hucitec,caps. 1 e 4.1997.

ROUSSEAU. J.J. Discurso sobre a origem e os fundamentos da desigualdade entre os homens. São Paulo, Martins Fontes 1993.

SGRECCIA, Elio. Identidade e Estatuto do Embrião Humano. São Paulo- Edusc.2007. SILVA, Franklin Leopoldo.

- A metafísica da Modernidade. São Paulo. Ed.Moderna -Martin Heidegger e a técnica.In: Scientiae Studia: Revista Latino Americana de Filosofia e História da Ciência. São Paulo, v.5,n.3,p.369-375.

SCHRÖDINGER, Erwin.O que é vida? O aspecto físico da célula viva.São Paulo:Editora Unesp.1977.

STURLUSSON,Snorri. EDDA em prosa- Textos da Mitologia Nórdica.Rio de Janeiro:Numen Editora, 1993.

VIEIRA, Sonia. Experimentação com seres humanos.São Paulo:Moderna, 1987.

VILLEY, Michel. Polêmica sobre "Os Direitos Humanos. Artigo fornecido pelo docente. 
Sites Consultados

http://www.culturalbrasil.com

http://pt.wiktionary.org/wikimedicina

http://www.hinduismo.org

http://www.ippb.org.br

http://www.arresala.org.br 